Universidade de Brasília

Faculdade de Economia, Administração, Contabilidade, Ciência da Informação e Documentação

Departamento de Ciência da Informação e Documentação

\title{
BIBLIOTECA ESCOLAR NO BRASIL: UM ESTUDO SOBRE VÁRIOS ASPECTOS
}

Pollyana da Silva Batista 
Pollyana da Silva Batista

\section{BIBLIOTECA ESCOLAR NO BRASIL: UM ESTUDO SOBRE VÁRIOS ASPECTOS}

Monografia apresentada ao curso de Bacharel em Biblioteconomia, pela Universidade de Brasília como requisito parcial para obtenção do título de bibliotecária.

Orientadora: Profa. Dra. Maria Alice Guimarães Borges

Brasília

Julho - 2009 
Batista, Pollyana da Silva.

Biblioteca escolar no Brasil: estudo de vários aspectos / Pollyana da Silva Batista. -- Brasília: Departamento de Ciência da Informação e Documentação, Universidade de Brasília, 2009. 122 p.; il.

Orientadora: Profa. Dra. Maria Alice Guimarães Borges.

1. Biblioteca escolar. 2. Biblioteca escolar no Brasil. 
UNIVERSIDADE DE BRASÍLIA (UnB)

Faculdade de Economia, Administração, Contabilidade e Ciência da Informação e Documentação (FACE)

Departamento de Ciência da Informação e Documentação (CID)

Curso de Graduação em Biblioteconomia (Bacharelado)

\section{Pollyana da Silva Batista}

Biblioteca escolar no Brasil: um estudo sobre vários aspectos

Aprovada por:

Maria Alice Guimarães Borges - Orientadora

Professora do Departamento de Ciência da Informação e Documentação (UnB)

Doutora em Ciência da Informação

Tarcísio Zandonade - Membro

Professor do Departamento de Ciência da Informação e Documentação (UnB)

Doutor em Ciência da Informação

Jurema da Silva Assunção - Membro

Bibliotecária do TJDFT 


\section{Dedicatória}

Dedico esta monografia à minha mãe Regina Lúcia Batista da Silva

que sempre me apoiou, estimulou e acreditou em mim. 


\section{Agradecimentos}

Agradeço:

A Deus por ter me dado forças e esperança durante a realização desta monografia;

À professora Maria Alice Borges, pelas orientações e correções, pela sugestão do tema, pela disposição em emprestar seus livros e revistas.

À minha tia Ana Maria, por ter disponibilizado o acesso ao seu computador para elaboração de parte desta monografia.

À bibliotecária Jurema Assunção pela disposição em participar da banca.

Ao professor Tarcísio Zandonade na colaboração com a bibliografia e pela disposição em participar da banca.

À professora Ellen Crista da Silva.

Ao casal Jorge Alaor Lima e Irene Lima, pelo apoio e incentivo. 


\section{Resumo}

Este documento é um estudo e tem por objetivo conhecer itens relativos à biblioteca escolar e itens pertinentes a sua situação, de forma sucinta no Brasil, e seguem: seu conceito e papel; sua estrutura e funcionamento; o acervo e sua organização; leitura e políticas públicas de leitura no Brasil; pesquisa escolar e, a utilização da Internet neste processo; papel do bibliotecário. A metodologia utilizada para a realização desta monografia foi uma revisão de literatura sobre a biblioteca escolar e aspectos relacionados com a mesma e o contexto dela no Brasil e um levantamento bibliográfico seletivo comentado de documentos acerca da biblioteca escolar brasileira; traz o conceito de Sociedade da Informação e do Conhecimento e, da biblioteca nesta sociedade. O levantamento tem transcrições de resumos de artigos, teses e dissertações, bem como de sumários, ou descrição, ou sinopse de livros, igualmente a transcrição da descrição de sites e uma base de dados na área de biblioteca escolar, e transcreve-se também palavras-chave dos documentos. A pesquisa do levantamento bibliográfico foi efetuada em sites de editoras e livrarias brasileiras, em catálogos de bibliotecas e bases de dados bibliográficas. Em suma, este trabalho permitiu à autora compreender a razão, pela qual a biblioteca escolar é um recurso complementar tão importante ao processo de ensino-aprendizagem, pois nela é possível desenvolver habilidades informacionais utilizando os materiais existentes em seu espaço, portanto é imprescindível ter documentos de qualidade, conforme apresentado no tópico pertinente a este assunto - o acervo e sua organização; igualmente a importância de um espaço adequado. Também proporcionou saber como se situa a questão da leitura no Brasil, por meio da pesquisa Retratos da Leitura no Brasil; do mesmo modo verificar como funciona o processo de pesquisa escolar e, a utilização da Internet neste processo; possibilitou inferir que existe ligação entre leitura, competência informacional e pesquisa escolar, uma vez que por meio da leitura apreende-se a informação, e a competência informacional é a aptidão para identificá-la, apreendê-la e aplicá-la, a pesquisa escolar é a forma, na qual o aluno irá unir a assimilação da informação e estas aptidões. Além disso, permitiu entender como é significante a figura do bibliotecário na biblioteca da escola, também que a literatura menciona de forma constante a necessidade de parcerias entre bibliotecários e professores, do mesmo modo que é preciso que ambas as áreas de Educação e Biblioteconomia tenham conhecimento do campo de conhecimento um do outro.

Palavras-chave: Biblioteca escolar. Biblioteca escolar brasileira. Biblioteca escolar - estrutura e funcionamento. Biblioteca escolar - acervo. Pesquisa escolar. Pesquisa escolar e Internet. Leitura. Competência informacional. Bibliotecário escolar. 


\begin{abstract}
This monograph is a study about aspects of school library and aspects relatives to brazilian school libraries, that are: concept and role of school library; its structure and functioning; the book collection and its organization; reading and publics policies of reading in Brazil; school search and the use of Internet in this process; the role of school librarian. The methodology used in this monograph was a state of art about school library and a selective literature search with comments, and the aspects previously mentioned; brings the concept of Information Science and the role of library in this society. The selective literature search with comments about school library in Brazil, include transcriptions of the contents list of books, transcriptions of abstracts of scientific papers and thesis and dissertations, and documents key-words, transcriptions of sites and database descriptions. The literature search was made in sites of brazilian publishing houses and bookstores. In short, this document allows to the author understands the reason why school library is a complement resource so important to the process teaching-learning, because on the school library it is possible develop skills informational using the materials existing in the school library, thus it is essential to the school library possess documents with high quality, according to showed in the topic pertinent to this matter (the book collection and its organization); the relevance of an appropriate space for this library. Provided to know, as well, how is the situation of the reading in Brazil, through da research "Retratos da Leitura no Brasil"; verify how the process of school search works and the use of Internet in this; it was possible infer that there is a relationship between reading and literacy information and school search, since the reading is the information assimilation, and information literacy is the skill to identify the information and apprehend it and apply it, the school search is the junction of both (reading and information literacy). Furthermore, this document allows to understand how is significant the school librarian, also that literature mentions many times about the need of a partnership between librarians and teachers, likewise that is necessary to both Education and Library Science to know each other.
\end{abstract}

Key-words: School library. Brazilian school library. School library - structure and functioning. School library - book collection. School search. School search Internet. Reading. Information literacy. School librarian. 


\section{Sumário}

1 Introdução 12

2 Objetivos $\quad 15$

2.10bjetivos gerais $\quad 15$

$\begin{array}{ll}\text { 2.2Objetivos específicos } & 15\end{array}$

3 Metodologia 16

4 Revisão de literatura 18

4.1Sociedade da Informação e do Conhecimento - SIC 18

4.2 Papel da biblioteca na Sociedade da Informação e 20

do Conhecimento - SIC
4.3 Biblioteca escolar

4.3.1 Conceito e papel 22

4.3.2 A estrutura e funcionamento da biblioteca escolar 24

4.3.2.1 Elementos que compõem o funcionamento 29

4.3.2.1.1 Setores da biblioteca escolar 29

$\begin{array}{ll}\text { 4.3.2.1.2 Horário e Freqüência } & 30\end{array}$

4.3.2.1.3 Localização da biblioteca 31

4.3.2.1.4 Equipamento da biblioteca escolar 32

4.3.3 O acervo escolar e sua organização 33

4.3.3.1 A relação acervo e educação infantil 36

4.3.3.2 Organização da informação na biblioteca escolar 39

4.3.3.3 Desenvolvimento de coleções - o processo de seleção $\quad 40$

e aquisição

4.3.4 Pesquisa escolar 44

4.3.4.1 Pesquisa escolar e Internet $\quad 52$

4.3.5 Biblioteca e leitura $\quad 58$

4.3.5.1 Políticas públicas de leitura no Brasil 65

4.3.6 Competência informacional $\quad 71$

4.3.7 Biblioteca escolar no Brasil $\quad 75$

4.3.7.1 Fatores externos e internos que levam 81

a não utilização da biblioteca

4.3.7.1.1 Fatores externos $\quad 81$

4.3.7.1.2 Fatores internos $\quad 82$

4.3.8 O papel do bibliotecário na biblioteca escolar 85

5 Considerações finais $\quad 89$

6 Levantamento bibliográfico seletivo comentado 91

sobre biblioteca escolar

6.1Artigos $\quad 91$

$\begin{array}{ll}6.2 \text { Livros } & 105\end{array}$

$\begin{array}{ll}6.3 \text { Site e base de dados } & 110\end{array}$

$\begin{array}{ll}\text { 6.4 Teses e Dissertações } & 111\end{array}$

$\begin{array}{ll}7 \text { Referências } & 117\end{array}$ 


\section{Lista de Figuras}

Figura 1- Número de autores e de capítulos escritos por eles

Figura 2 - Freqüência de citação

Figura 3 - Mudanças provocadas pela Sociedade de Informação

Figura 4 - Como eram as pesquisas no primeiro de atividade da bibliotecária 


\section{Lista de siglas}

AASL - American Association of School Librarians

AECT - Association for Educational Communications and Technology

CBBD - Congresso Brasileiro de Biblioteconomia e Documentação e Ciência da Informação

CDD - Classificação Decimal de Dewey

CDU - Classificação Decimal Universal

CE - Comissão de Educação, Cultura e Esporte/Senado Federal

GEBE - Grupo de Estudos em Biblioteca Escolar, Escola de Ciência da Informação da Universidade Federal de Minas Gerais

GBAE - Grupo de Bibliotecários da Área Escolar de Santa Catarina

IBGE - Instituto Brasileiro de Geografia e Estatística

Ifla - Federação Internacional de Associações e Instituições Bibliotecárias

(International Federation of Library Associations and Institutions)

LDB - Lei de Diretrizes e Bases

LIBES - Literatura Brasileira em Biblioteca Escolar

OEA - Organização dos Estados Americanos

PCN - Parâmetros Curriculares Nacionais

PNAD - Plano Nacional por Amostragem de Domicílio

PNLL - Plano Nacional do Livro e Leitura

SEDUC - Secretaria de Estado de Educação do Pará

SEE - Secretaria de Estado de Educação (MG)

SIBES - Sistema Informatizado de Bibliotecas Escolares do estado da Bahia

SIC - Sociedade da Informação e do Conhecimento

SIEBE - Sistema Estadual de Bibliotecas Escolares do estado do Pará

SMEC - Secretaria Municipal de Educação e Cultura do estado da Bahia

UFMG - Universidade Federal de Minas Gerais

UNESCO - Organização das Nações Unidas para a Educação, Ciência e a Cultura 


\section{Introdução}

A biblioteca escolar constitui um importante instrumento no auxílio da aprendizagem dos alunos. É a biblioteca que servirá de suporte ao ensino e servirá de base ao processo de ensino-aprendizagem, no qual se estabelece como o aluno assimila informação, a utiliza e se relaciona com a mesma, não somente durante os primeiros anos na escola, mas também ao longo de sua vida. Ela é além de uma extensão, a complementação da própria sala de aula, onde os alunos fazem pesquisa, se informam, se entretem e desenvolvem sua capacidade de adquirir conhecimento.

Uma biblioteca com profissionais capacitados e especializados, com acervo de qualidade, com programas escolares bem planejados, por meio de uma parceria entre bibliotecários e professores é o ideal para que esta atinja o seu maior objetivo que é dar apoio ao processo de ensino-aprendizagem do aluno.

A razão de se fazer um estudo sobre biblioteca escolar no Brasil é para mostrar o lugar que é dado ao tema, se realmente, há interesse pelo assunto na literatura biblioteconômica brasileira, bem como verificar a realidade da biblioteca escolar no Brasil, contribuindo para a divulgação do assunto no meio acadêmico.

Esta monografia pretende estudar temas relacionados à biblioteca escolar no Brasil, como: o papel da biblioteca escolar; sua estrutura; a questão da pesquisa escolar e sua relação com a Internet; o papel do bibliotecário neste contexto.

A realidade da biblioteca escolar no Brasil é deficitária, segundo a literatura e observações de especialistas. Conforme Silva (1995, p. 44) "escrever sobre a biblioteca escolar brasileira é tocar numa das maiores deficiências do nosso aparelho escolar. Desde os colégios dos jesuítas - nossa primeira experiência de educação formal - até os dias atuais, muito pouco se fez em relação à biblioteca 
escolar".

Uma consulta exaustiva a diversos documentos, principalmente à publicação "A biblioteca escolar: temas para uma prática pedagógica" ${ }^{1}$ constituiu-se na base para elaboração dos tópicos desta monografia. Foi realizado um estudo bibliométrico para analisar sua composição, obtendo os seguintes resultados: de um total de 17 autores, seis - escreveram capítulo - e treze foram citados (um dos trabalhos citados foi escritos em dupla).

Dentre os autores citados, doze são brasileiros, cinco são estrangeiros, sendo um destes, uma entidade.

O livro contém doze capítulos. Seis autores redigiram os capítulos e cada um escreveu dois deles.

As figuras um e dois, a seguir, mostram o número de vezes que os autores escreveram capítulo e a freqüência de citações:

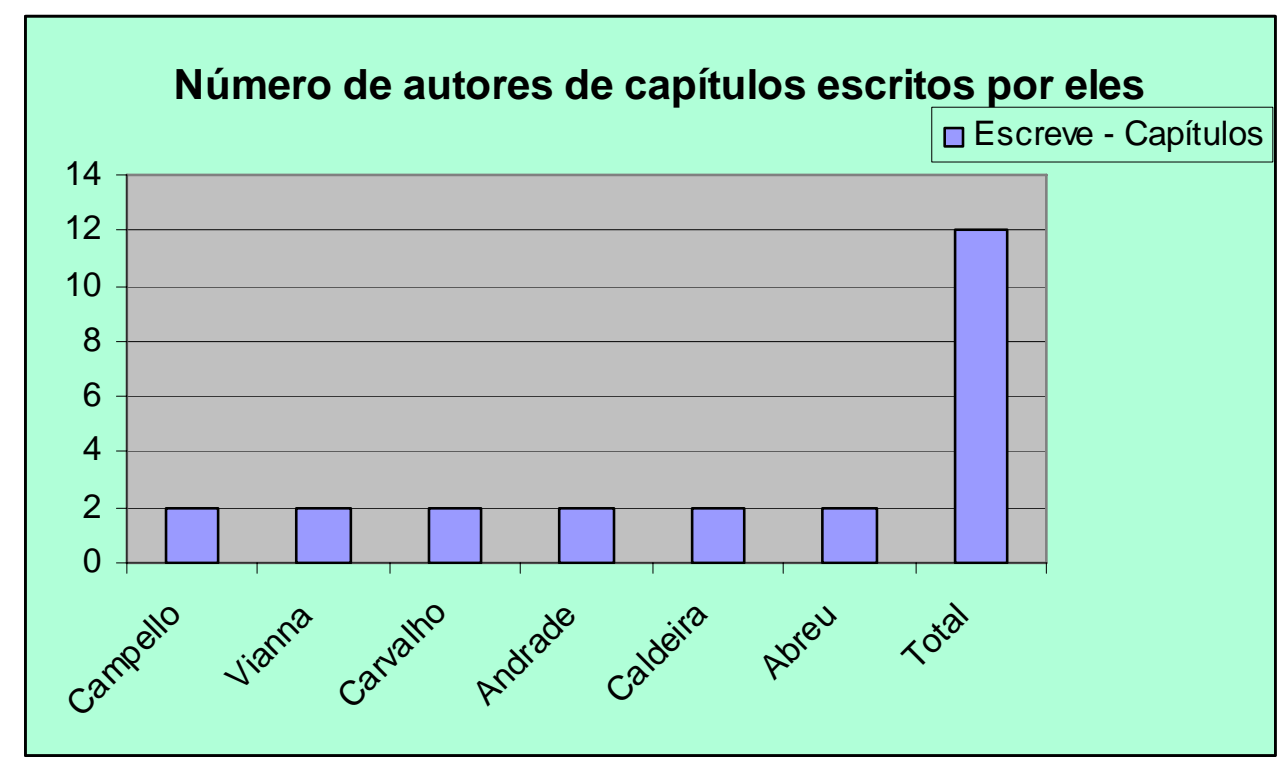

Figura 1- Número de autores e de capítulos escritos por eles

\footnotetext{
${ }^{1}$ CAMPELLO, Bernadete et al. A biblioteca escolar... 2. ed. Belo Horizonte: Autêntica, 2005. 62 p.
} 
É possível observar, por meio da Figura 1, o número de vezes que alguns autores redigiram capítulo ou parte no livro.

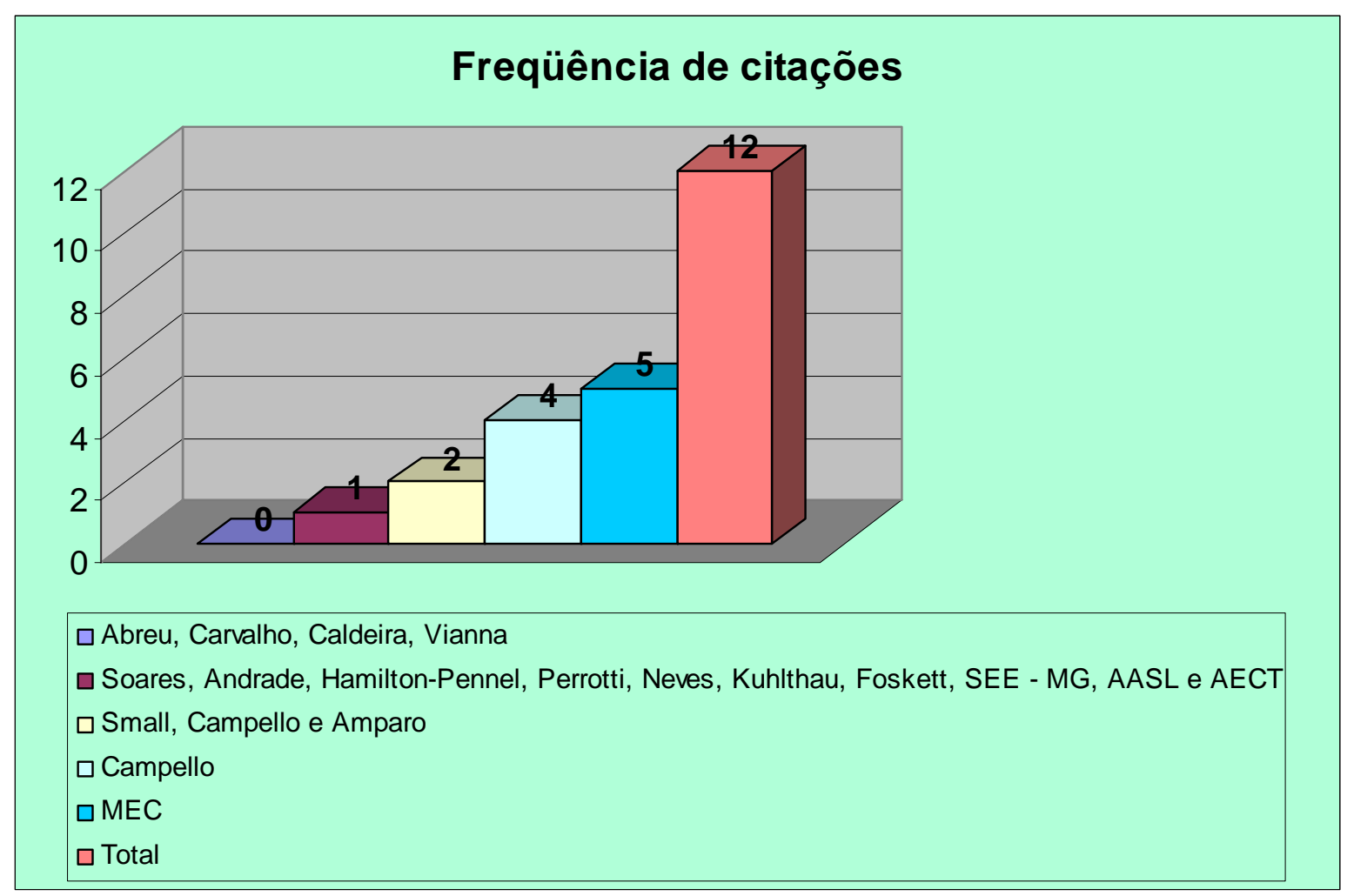

Figura 2 - Freqüência de citações

Nesta Figura 2, observa-se a freqüência em que os autores são citados, sendo que se destacam como mais citadas: o Ministério da Educação (MEC), que é uma entidade e, Campello como autor pessoal; os menos citados são Soares (brasileiro), Foskett (estrangeiro) e a Secretaria de Estado de Cultura de Minas Gerais (entidade). 


\section{Objetivos}

\subsection{Objetivo geral}

Estudar a situação da Biblioteca Escolar, a sua realidade no Brasil, e vários aspectos relativos a ela.

\subsection{Objetivos específicos}

2.2.1 Estudar a biblioteca escolar quanto:

a) ao seu papel;

b) ao seu funcionamento, seu acervo e organização e a relação entre coleção e educação infantil;

c) à pesquisa escolar, a Internet dentro do processo de pesquisa;

d) ao papel do bibliotecário neste tipo de biblioteca;

e) à realidade das bibliotecas brasileiras;

f) à leitura e políticas públicas desenvolvidas pelo governo brasileiro;

g) à competência informacional a ser desenvolvida pelos alunos.

2.2.2 Levantar a bibliografia seletiva comentada sobre biblioteca escolar 


\section{Metodologia}

A metodologia utilizada para a elaboração desta monografia é composta de duas partes: a primeira é a revisão de literatura e a segunda é o levantamento bibliográfico comentado.

$\mathrm{Na}$ revisão de literatura foi feito um levantamento sobre a biblioteca na escola brasileira e os temas concernentes à mesma, citados anteriormente nos objetivos específicos.

A revisão bibliográfica traz o conceito de biblioteca na Sociedade da Informação e do Conhecimento e da biblioteca escolar e vários itens relativos a ela, como: a pesquisa escolar e o uso da Internet no processo de pesquisa; a leitura e algumas políticas públicas que estão sendo desenvolvidas pelo governo brasileiro acerca de leitura; a competência informacional; o papel do bibliotecário; biblioteca escolar, e outros.

Foi realizada uma pesquisa bibliográfica em periódicos especializados na área de Ciência da Informação e Biblioteconomia, livros, anais de congresso e seminários, sites do governo, do Grupo de Estudos em Biblioteca Escolar da Escola de Ciência da Informação da UFMG - GEBE, também site do Grupo de Bibliotecários da Área Escolar de Santa Catarina . Vale destacar a utilização da base bibliográfica LIBES - Literatura Brasileira em Biblioteca Escolar (desenvolvida pelo grupo GEBE), , entre outros que estão relacionados ao tema.

O levantamento bibliográfico seletivo comentado foi elaborado a partir de dados que foram transcritos de partes relevantes do sumário, que fizessem sentido para uma compreensão do conteúdo abordado; de palavras-chaves encontradas nas bases de dados bibliográficas ou catálogos de bibliotecas e, igualmente, na transcrição dos resumos dos artigos de periódicos, de teses e dissertações. 
Foram realizadas buscas nos catálogos de editoras e livrarias brasileiras para localizar documentos, dos quais foram retirados trechos da descrição ou sinopse encontrada nos mesmos catálogos. O levantamento bibliográfico foi organizado por ordem alfabética dos autores. 


\section{Revisão de literatura}

\subsection{Sociedade da Informação e do Conhecimento - SIC}

A Sociedade da Informação e do Conhecimento pode ser explicada como a "etapa do desenvolvimento da sociedade que se caracteriza pela abundância de informação organizada" (ARAÚJO E DIAS, 2005, p. 113).

A partir de estudos de teóricos como Machlup e Drucker, surgiu o termo sociedade da informação ou sociedade pós-industrial - como era denominada por Machlup. Este elaborou um estudo quantitativo mostrando como a informação nos Estados Unidos poderia fazia parte do Produto Nacional Bruto (PNB) daquele país. Drucker a partir da análise de Machlup previu que, em 1970 metade do PNB dos Estados Unidos seria composto pelo setor do conhecimento.

Segundo Araújo e Dias (2005, p. 115), este termo aparece na literatura biblioteconômica nos anos de 1970. Os autores atentam para a questão do acesso à informação produzida nessa sociedade da informação e do conhecimento, que vários são os modos possíveis para a transmissão da informação.

Segundo Borges (2000, p. 28) do ponto de vista econômico a informação e o conhecimento são considerados como bens primordiais e que estes dois não se acabam com o uso. Pois, por meio de sua utilização "há um processo de interpretação, de interligação [...] promovendo um ato de criação e invenção". E mais "o uso da virtualização, cada vez mais presente no nosso cotidiano, amplia as potencialidades humanas, criando novas relações, novos conhecimentos, novas maneiras de aprender e pensar" (2000, p. 29).

O quadro explicativo, apresentado na Figura 3, elaborado por Bells (apud SANTOS, 1989, apud ARAÚJO e DIAS, 2005, p. 115), exemplifica as transformações provocadas por essa sociedade. 


\begin{tabular}{|c|c|c|c|}
\hline & Pré-industrial & Industrial & Pós-industrial \\
\hline Regiões & $\begin{array}{l}\text { Ásia, África, América } \\
\text { Latina }\end{array}$ & $\begin{array}{l}\text { Europa Ocidental e } \\
\text { Oriental }\end{array}$ & $\begin{array}{l}\text { E.U.A, Japão, Centros } \\
\text { Europeus }\end{array}$ \\
\hline Setores & $\begin{array}{l}\text { Primário: caça, pesca, } \\
\text { agricultura, extração }\end{array}$ & Secundário: industrial & $\begin{array}{l}\text { Terciário: } \begin{array}{l}\text { serviços, } \\
\text { saúde, } \\
\text { educação, ponsumo, } \\
\text { comunicação }\end{array} \\
\text { comaisa, }\end{array}$ \\
\hline Ocupação & $\begin{array}{l}\text { Agricultor, mineiro não } \\
\text { especializado }\end{array}$ & $\begin{array}{l}\text { Operário } \\
\text { especializado, } \\
\text { engenheiro }\end{array}$ & $\begin{array}{l}\text { Técnicos, cientistas, } \\
\text { artistas, professores }\end{array}$ \\
\hline Tecnologia & Matérias-primas & Energia & Informação \\
\hline Projeto & Jogo com a natureza & Jogo com a máquina & Jogo entre as pessoas \\
\hline Metodologia & $\begin{array}{l}\text { Senso comum, } \\
\text { experimentação }\end{array}$ & $\begin{array}{l}\text { Experimentação, } \\
\text { empirismo }\end{array}$ & $\begin{array}{l}\text { Invenção, } \\
\text { originalidade, teoria, } \\
\text { modelos, sistemas, } \\
\text { simulação } \\
\text { computacional }\end{array}$ \\
\hline Perspectiva & Passado/repetição & Presente/adaptação & Futuro/programação \\
\hline Princípio & Tradição/terra & Expansão econômica & $\begin{array}{l}\text { Descentralização, } \\
\text { codificação do } \\
\text { conhecimento }\end{array}$ \\
\hline
\end{tabular}

Fonte: Bells (apud SANTOS, 1989, apud ARAÚJO e DIAS, 2005, p. 115)

Figura 3 - Mudanças provocadas pela Sociedade da Informação

A Sociedade da Informação e do Conhecimento possui algumas

características, como afirma Borges (2000, p. 29):

- A informação é um produto, um bem comercial;

- O saber é um fator econômico;

- As tecnologias de informação e comunicação vêm revolucionar a noção de "valor agregado" à informação;

- A distância e o tempo entre a fonte de informação e o seu destinatário deixaram de ter qualquer importância; as pessoas não precisam se deslocar porque são os dados que viajam;

- A probabilidade de se encontrarem respostas inovadoras a situações críticas é muito superior à situação anterior;

- As novas tecnologias criaram novos serviços e mercados, serviços, empregos e empresas; entre outros.

- As tecnologias de informação e comunicação interferiram no "ciclo informativo", tanto do ponto de vista dos processos, das atividades, da gestão, dos custos etc.:

- O próprio usuário da informação pode ser também o produtor ou gerador da informação;

- Registro de grandes volumes de dados a baixo custo;

- Armazenamento de dados em memórias com grande capacidade;

- Processamento automático da informação em alta velocidade;

- Recuperação de informação, com estratégias de buscas automatizadas;

- Acesso às informações armazenadas em bases de dados em vários locais ou instituições, de maneira facilitada;

- Monitoramento e avaliação do uso da informação.

A estrutura da SIC tem como fundamento três bases segundo Araújo e Dias

(2005, p. 116-118), que são a base teórica, as bases materiais e a base política. 
A base teórica diz que "a substituição da produção industrial pela informação", é uma troca de atividades de cunho industrial por tarefas que tenham como apoio o "tratamento da informação" (2005, p. 116).

As bases materiais dessa sociedade estão relacionadas às novas tecnologias de informação. As mesmas, por sua vez, dizem respeito a tarefas que abrangem o processamento e o envio de informações. É possível citar como exemplo de tecnologias de informação: "telecomunicações via satélite, processamento de imagens, [...] EDI (transferência eletrônica de dados) [e outras. Essas tecnologias tornam possíveis] a criação, circulação e o armazenamento de uma imensa massa de informação" (ARAÚJO e DIAS, 2005, p. 117).

A base política remete à ligação entre "informação e estrutura de poder" e que de acordo com Araújo e Dias (2005, p. 118), pode ser percebido pela "questão da informação para a dominação ou para a conscientização social". Mencionam ainda, que

a capacitação dos cidadãos para utilizar os instrumentos e serviços oferecidos pelas redes de comunicação eletrônica e potencializar as informações acessadas, ou seja, a capacidade de compreender as informações, tornando-as úteis e componentes de sua vida cotidiana.

Além disso, a questão citada anteriormente acerca da capacitação dos cidadãos - segundo aqueles autores - é uma dificuldade não resolvida e que é a partir deste fato que entram em cena a biblioteca e o bibliotecário.

\subsection{Papel da biblioteca na Sociedade da Informação e do Conhecimento}

A biblioteca, como organização social, é definida por vários especialistas, por exemplo, segundo Cortez (1987, p. 193 apud ARRUDA e CHAGAS, 2002) a biblioteca pode ser definida como uma forma de se obter a informação e não uma finalidade em si mesma. A biblioteca também foi conceituada como sendo 
“organismos que têm por missão coletar e gerar documentos para permitir a consulta: elas dispõem de ferramentas e de pessoas que ajudam a recuperar os documentos arquivados que podem responder à solicitação" (MANUAL, 1997, p. 151 apud ARRUDA e CHAGAS, 2002).

De acordo com Pimentel (2006, f. 24) "pela sua etimologia, biblioteca é uma instituição destinada, essencialmente, à conservação e circulação ativa da informação, por meio de seus diversos suportes".

Milanesi escreve que a biblioteca é uma estrutura pela qual "a memória da humanidade" pode ser contida. É o local onde a produção do conhecimento humano é administrada por "pessoas especializadas que não só a preserva como a organiza de tal forma que a menor unidade possa ser perfeitamente localizável". Afirma ainda o autor que é o lugar no qual a informação registrada é mantida, onde são preservados "registros de sucessivas gerações", onde é possível ordená-la e facilitar o acesso à mesma (2002, p. 9-12).

Segundo historiadores, as bibliotecas existem desde o antigo Egito e podese citar como exemplo a biblioteca de Alexandria. Sempre foram vistas como um local no qual se pode adquirir conhecimento. Partindo desta idéia, pode-se afirmar que o papel da biblioteca é de organizar e facilitar o acesso à informação e estimular a leitura e o conhecimento. No caso de uma biblioteca subordinada a uma instituição, um dos papéis é oferecer suporte informacional de acordo com sua missão e objetivos, auxiliar no ensino e aprendizagem, entre outros. Existem diversos tipos de bibliotecas, os quais são: bibliotecas nacionais, públicas, escolares, especializadas, especiais, universitárias, infantis e comunitárias.

No entanto, o tema desta monografia pretende discorrer sobre a biblioteca escolar, no Brasil e assuntos relacionados à biblioteca escolar. 


\subsection{Biblioteca escolar}

\subsubsection{Conceito e papel}

A biblioteca escolar se constitui num instrumento de auxílio ao processo de ensino-aprendizagem. Campello (2003, apud ABREU et al. 2004, p. 20) faz menção de biblioteca escolar como a representação do "espaço para o desenvolvimento de habilidades de localização, seleção, interpretação e uso da informação, essenciais para se viver numa sociedade de abundância de informação".

A partir dos textos consultados, foi possível compreender que o papel da biblioteca escolar é principalmente ser uma ferramenta de apoio ao sistema educacional, caracterizada como um fator de incentivo e renovação às diversas etapas do ensino-aprendizagem (LÉON apud OEA, 1985).

É igualmente papel da biblioteca escolar, propiciar a uniformidade de oportunidades de formação, isto é, instigar as habilidades inerentes a cada sujeito - ou segundo a Organização dos Estados Americanos (1985, p. 26) cada pessoa tem chances de estar num patamar de igualdade no que diz respeito a oportunidades conforme suas aptidões, bem como beneficiar a interação entre crianças de diferentes idades, ser um mecanismo que favoreça o ato de socializarse e de autoformação do sujeito (OEA, 1985).

É também de sua competência divulgar a informação em diversos formatos e tipos de registro como livros, revistas, CDs-ROM, filmes, microformas, entre outros; auxiliar na etapa de desenvolvimento do hábito de leitura; ser um complemento ao processo de ensino, cooperando de forma ativa com este; disponibilizar material de acordo com as necessidades informacionais e com o 
currículo escolar, tornando aptos àqueles que têm interesse na informação

requerida - a manusear os livros e aumentar a habilidade para a pesquisa, e de

forma semelhante dar suporte aos programas de ensino (PERUCCHI, 1999, p. 81).

Segundo Fragoso (2002) também é papel da biblioteca escolar:

\begin{abstract}
a)cooperar com o currículo da escola no atendimento às necessidades dos alunos, dos professores e dos demais elementos da comunidade escolar;

b)estimular e orientar a comunidade escolar em suas consultas e leituras, favorecendo o desenvolvimento da capacidade de selecionar e avaliar;

c)incentivar os educandos a pensar de forma crítica, reflexiva, analítica e criadora, orientados por equipes inter-relacionadas (educadores + bibliotecários);

d)proporcionar aos leitores materiais diversos e serviços bibliotecários adequados ao seu aperfeiçoamento e desenvolvimento individual e coletivo;

e)promover a interação educador - bibliotecário - aluno, facilitando o processo ensino-aprendizagem;

f)oferecer um mecanismo para a democratização da educação, permitindo o acesso de um maior número de crianças e jovens a materiais educativos e, através disso, dar oportunidade ao desenvolvimento de cada aluno a partir de suas atitudes individuais;

g)contribuir para que o educador amplie sua percepção dos problemas educacionais, oferecendo-lhe informações que o ajudem a tomar decisões no sentido de solucioná-los, tendo como ponto de partida valores éticos e cidadãos.
\end{abstract}

Conforme Campello (2005, p. 17-18), os Parâmetros Curriculares Nacionais

(PCN) entendem como papéis da biblioteca escolar:

- [desenvolver] um programa de leitura eficiente, que forme leitores competentes e não leitores que façam isso de forma esporádica e saibam compreender o que lêem e desenvolvam práticas de intertextualidade;

- [esta dever ser um] local apto a influenciar o gosto pela leitura [os PCN recomendam] que a escola estimule o desejo de freqüentar esse espaço e contribuir pelo apreço do ato de ler;

- [também deve ser um local] de aprendizagem permanente, um centro de documentação onde se encontre informações que irão responder aos questionamentos levantados dentro das diversas áreas curriculares; - [estar apropriada para] desenvolver atitudes de cidadania, [onde os alunos aprendam, por exemplo, a respeitar o ambiente coletivo, atitudes de respeito ao livro e outros materiais e] tenham condições de generalizar o conceito de espaço público, reconhecer [outros espaços mais amplos, como o de cidades e mais abstratos como instituições].

Em suma, diante do que foi afirmado pelos especialistas, é possível

perceber quantos papéis e responsabilidades a biblioteca escolar exerce: apoiar o 
processo de ensino-aprendizagem; promover a interação entre os indivíduos, a fim de que haja sociabilização dos estudantes; ser um espaço onde os estudantes aprendam a conviver com as diferenças; um local que promova a cidadania e o entendimento do respeito ao espaço público e ao patrimônio; incentivar o gosto pela leitura; propiciar o contato com diversos suportes de informação.

Ela constitui, também, um estoque de informações para que os alunos aprendam de forma contínua e compreendam sua organização e funcionamento, são mais alguns papéis que a biblioteca da escola desempenha.

\subsubsection{Estrutura e funcionamento da biblioteca escolar}

Com relação ao espaço físico de uma biblioteca e como ele funciona, deve ser planejada a distribuição dos móveis neste espaço, como as estantes, mesas de estudos; dos equipamentos de informática; das salas ou cabines de estudos individuais ou em grupos; dos espaços para os diferentes materiais que compõem a coleção, como os audiovisuais, eletrônicos e impressos.

Caldeira (2005, p.47) menciona que a imagem que se tem do interior de uma biblioteca, é de um local com salas para estudo, mesas para estudo em grupo e individual. Em determinadas bibliotecas existe o espaço para brinquedotecas e crianças fazendo os trabalhos escolares, uma parte reservada aos livros e as prateleiras com revistas, entre outros.

A biblioteca tem seu espaço expandido por meio da Internet, formando um espaço virtual onde o indivíduo pode consultar a informação de qualquer lugar em que esteja. Apesar do acesso remoto à informação, muitas pessoas continuarão a freqüentar a biblioteca (CALDEIRA, 2005, p. 47).

Pelo espaço físico, verifica-se qual é o valor que é conferido à biblioteca da 
instituição na qual está submetida (CALDEIRA, 2005, p. 47). O valor que uma instituição de ensino confere à sua biblioteca é observando a situação na qual ela se encontra, se o espaço é bem utilizado, se é predominante na escola sua "função educativa [...] visando a proporcionar aos alunos oportunidades de leitura intensa e autônoma, além de incentivar a busca de informações para responder a questionamentos e solucionar problemas" (CALDEIRA, 2005, p. 47-48).

É imprescindível "a preocupação em oferecer ambiente acolhedor" (CALDEIRA, 2005, p. 48) com a finalidade de intensificar a leitura. Logo, essa preocupação

\begin{abstract}
levou à criação, nas bibliotecas, de espaços aconchegantes, visando especialmente a atrair crianças menores que se encontram na idade de descobrir o gosto pelas histórias contadas ou lidas pelos adultos. Tapetes, almofadas, móveis coloridos [constituem um atrativo para] despertar e manter um comportamento positivo da criança em relação à leitura (CALDEIRA, 2005, p. 48).
\end{abstract}

Para que a biblioteca tenha um ambiente agradável é necessário que se faça um planejamento detalhado e este "deve ser feito em função do acervo e do uso que se pretende dele". Deve-se levar em conta o acervo, o local destinado à coleção de referência e periódicos, salas de estudo individual e de grupos, lugar separado para a coleção infantil, sala de projeções ou auditório, laboratório de informática, espaço para multimeios, entre outros. Caldeira afirma que se os recursos citados não puderem ser implementados, é necessário que se planeje minuciosamente as "atividades na biblioteca, otimizando-se o uso dos locais disponíveis" (CALDEIRA, 2005, p. 48).

Segundo Tavares (1973, p. 23) a coleção, o professor e o bibliotecário configuram como elementos fundamentais para o funcionamento de uma biblioteca escolar e, que o sucesso da mesma depende deles. Porém vai se tratar do tema coleção no tópico especificado no sumário. 
Outro fator citado por Tavares (1973, p. 26) como básico para o funcionamento da biblioteca escolar é a figura do professor. Segundo ela, este profissional utiliza a biblioteca "para seu esclarecimento e estudo, indicando-a ao [aluno] para o mesmo fim". Do mesmo modo, este deve complementar o ensino ministrado em sala de aula com "a bibliografia do assunto com um endereço que será a chave do estudo". Assim, o número de chamada do item utilizado tem como base o sistema de classificação existente na biblioteca e é a partir do mesmo que o aluno terá acesso à informação. A autora afirma que é de grande responsabilidade do professor instigar o aluno a fazer uso da biblioteca da escola, e, que essa atitude "possibilita ampla informação, melhor aprendizagem, maiores esclarecimento e aperfeiçoamento" (TAVARES, 1973, p. 26).

Além disso, mostra outras vantagens da influência que o professor exerce no aluno em relação à utilização da biblioteca, que são a atitude de pesquisar, leitura de diversos livros, a assimilação do conteúdo, desenvolvimento do raciocínio, levando o estudante a fazer inferências a respeito dos assuntos pesquisados, a desenvolver o pensamento crítico, e outros. Logo, tornando-o menos limitado quanto à questão da aprendizagem.

Sugere Tavares que o professor deve promover trabalhos em grupo, fazendo que a biblioteca seja o meio para tal fim. Este deve certificar-se que todos os alunos estarão contribuindo na atividade proposta, para que todos aprendam de maneira uniforme (1973, p. 26). Outras funções que Tavares cita como sendo do professor são de orientar os alunos quanto à elaboração da pesquisa escolar; da obrigação de zelar pelo patrimônio; de "indicar bibliografias do que existe na Biblioteca" (1973, p. 27).

Cabe ainda ao professor "sugerir ao Bibliotecário os livros mais úteis e 
necessários aos seus alunos, dentro de sua especialidade. Cooperará com o Bibliotecário na aquisição, seleção de livros, na redação de resumos". Logo, sua participação se faz imprescindível, pois através de uma parceira entre bibliotecário e o professor resultará "um bom rendimento educativo" dos estudantes (TAVARES, 1973, p. 27).

Sobre a função do bibliotecário (TAVARES, 1973, p. 27), Tavares explica quais são seus papéis e que é essencial a existência deste profissional para o sucesso da biblioteca escolar.

Tavares enumera as razões, pelas quais é importante a presença do bibliotecário: a ele cabe cuidar para que o material disponível seja atualizado e adequado às necessidades dos estudantes e apropriado ao currículo escolar. É da responsabilidade do bibliotecário:

Tornar a Biblioteca dinâmica, pronta a servir ao aluno com eficiência [...] Fornecer a informação rápida, encontrar o material adequado, ir ao encontro do que o aluno precisa e deseja [...] Atender ao programa escolar, num entrosamento constante com o Professor de diversas classes, a fim de dispor do material, da bibliografia e da informação prontos para quando o aluno e o professor solicitarem. Acompanhar a vida escolar [...] no que se refere às atividades do ensino e às extra-escolares, comemorações, [entre outros] (TAVARES, 1973, p. 27).

É de sua competência estimular a utilização dos diversos recursos informacionais existentes na biblioteca, bem como estar à frente de atividades tais como exposições e concursos. Orientar o professor para que este auxilie o aluno no aproveitamento exaustivo dos materiais da biblioteca e quanto à utilização do espaço da mesma, da mesma forma orientar o aluno qual o modo de elaborar uma pesquisa, como fazer levantamento bibliográfico, entre outros (TAVARES, 1973, p. 27).

Portanto, observa-se o quão imprescindível é o bibliotecário para o funcionamento da biblioteca, como um profissional qualificado e especializado para 
exercer essas funções.

Outro fator que influencia no funcionamento da biblioteca escolar é o recurso financeiro. Segundo Anísio Teixeira (apud TAVARES, 1973, p. 28) "educação é um serviço caro". O recurso financeiro é um elemento imprescindível, pois dele estão sujeitos itens como "acervo adequado e atualizado, a realizações de atividades paradidáticas, a apresentação adequada e a tempo do material necessário ao leitor, [igualmente] a renovação e a conservação [da coleção] são condições essenciais" (TAVARES, 1973, p. 28).

Tavares afirma que é indispensável entender o "valor educativo de investimento dos recursos [...] necessários" à biblioteca escolar (1973, p. 28).

Por meio da renovação e conservação é possível deixar o acervo no estado apropriado para utilização, por que um dos objetivos da biblioteca é que se tenha acesso à informação. É preciso a manutenção da coleção, conforme discorre Tavares e a tarefa de manter, renovar e conservar o acervo, é possibilitada pelo recurso financeiro (1973, p. 28). A autora afirma que a maior preocupação das autoridades competentes é inaugurar serviços públicos, como as bibliotecas, do que destinar recursos para mantê-las.

De acordo com Mary P. Douglas (apud TAVARES, 1973, p. 28-29) são fatores imprescindíveis para o andamento dos serviços da biblioteca escolar:

1. uma coleção de livros cuidadosamente selecionada a fim de proporcionar às crianças, variedade em suas leituras e atualidade nos seus conhecimentos, para que o se ampliará e renovará o material permanente;

2. um salão de leitura com mobiliário apropriado, luz adequada, estantes suficientes e bastante espaço para acomodar os alunos ou seja, biblioteca proporcional à matrícula da escola;

3. um bibliotecário profissional que tenha tido também preparação como mestre e cujo salário esteja em proporção aos seus conhecimentos e capacidade;

4. oportunidade para que as crianças usem a biblioteca a qualquer hora do dia escolar; 
5. um corpo de professores que dê vida ao trabalho de classe por meio dos materiais da Biblioteca;

6. um Diretor que esteja convencido do que significa para a sua Escola uma Biblioteca ativa, prestigiando e conseguindo recursos suficientes para sua manutenção, junto às autoridades competentes.

Por último, Tavares menciona que para haver um bom funcionamento da biblioteca escolar é interessante que ela seja uma "organização racional e objetiva", e que a habilidade do profissional da informação em se adaptar para realizar essa tarefa seja do mesmo modo relevante (1973, p. 29).

\subsubsection{Elementos que compõem o funcionamento da biblioteca escolar}

Outros elementos citados na literatura aparecem como componentes do funcionamento da biblioteca escolar, por exemplo: aspectos técnicos da seleção e aquisição, os setores que devem existir, o horário de funcionamento, a freqüência dos usuários, a localização, o equipamento, e outros. Entretanto, o tema relativo à seleção e aquisição será tratado no tópico o acervo da biblioteca escolar e sua organização.

\subsection{Setores da biblioteca escolar}

Acerca dos setores da biblioteca, Tavares julga imprescindível a existência da seção de referência combinada à seção de leitura; uma seção circulante, uma de serviços técnicos e uma de serviços administrativos. No setor de referência se encontram os materiais de consulta, pesquisa e informação como guias, dicionários, enciclopédias, entre outros. Na seção de leitura recomenda que estejam "as biografias, os livros de assunto e os recreativos"; e, recomenda que seja possível que a organização da mesma se faça por meio de módulos ou estantes "que não [as] separem totalmente, mas definam a localização dos livros" 
(1973, p. 30).

A respeito da seção circulante, afirma Tavares (1973, p. 31) que todos os livros pertencentes à mesma, serão para empréstimo, até mesmo dicionários e atlas, pois numa biblioteca escolar - escreve a autora - pelo fato de utilizarem-na alunos carentes - subentende-se que seja na biblioteca de escola pública, faz-se necessário essa prática.

Ao setor de processos técnicos compete o tratamento da informação adquirida e preparação da mesma pela biblioteca. De acordo com Tavares, suas funções são selecionar, registrar, classificar e catalogar o material e prepará-lo para empréstimo, recortes, e outros. Adjacente a este setor, encontrar-se-á o serviço de documentação que será incumbido "de selecionar e preparar recortes de jornais e revistas sobre assuntos de interesse dos leitores e gravuras que" poderão ser utilizadas pelos professores "na motivação de aulas ou pela própria [biblioteca] na organização de suas exposições" (1973, p.31).

\subsection{Horário e Freqüência}

O horário de funcionamento da unidade de informação deve ser integral, ou seja, atender no turno matutino e vespertino, e se, necessário, no período noturno, recomenda Tavares (1973, p. 31).

Entende-se que este termo freqüência esteja relacionado a fatores, como a quem é destinado o espaço da biblioteca escolar, isto é, a todos os alunos e professores. É possível que alunos e professores oriundos de outras escolas utilizem-na, mas Tavares adverte que provavelmente isso cause problemas quanto ao controle e haja confusão. Ela sugere que se faça intercâmbio entre as bibliotecas para a realização do empréstimo dos documentos (1973, p. 31). 
Cita ainda que a instituição de ensino, seja particular ou pública, não deve a seção de circulação de sua biblioteca cobrar multas por atraso e aconselha a suspensão do empréstimo equivalente aos dias que o indivíduo demorou a realizar a devolução do(s) livro(s) e outros documentos (TAVARES, 1973, p. 31), para a biblioteca não ser vista como um local de punição e passe a ser freqüentada cada vez mais.

\subsection{Localização da biblioteca}

O local destinado à biblioteca dentro da escola é uma das questões discorridas por Tavares. Ao citar este item, deve-se levar em conta onde se localizará a biblioteca e a quais ruídos que ela pode estar exposta. A biblioteca precisa estar em um espaço onde haja silêncio, seja bem arejado, bem iluminado, enfim, um ambiente aconchegante e atraente (1973, p. 32).

Recomenda Tavares que a biblioteca da escola disponha de no mínimo três salas: "uma destinada à Seção de Leitura e Referência; outra para a Circulante e outra para os Serviços Técnicos e Administrativos" (1973, p. 32). Caso não haja meios e espaço disponível, é preciso que o bibliotecário faça uma adaptação para maximizá-lo, utilizando, por exemplo, estantes de face dupla, módulos, para não perder espaço.

Ruth de Souza (apud TAVARES, 1973, p. 32) aconselha que ao escolher o espaço é preciso que se evite:

1. proximidade do pátio de recreio e campo de esportes;

2. vizinhança de salas de música e auditórios;

3. últimos andares de prédios, sem elevadores especialmente;

4. pavilhão isolado das salas de aula;

5. saguão de entrada, de passagem obrigatória;

6. vão escuro sob as escadas;

7. salas sem entrada independente. 
Tavares faz menção que os governos deveriam incluir no projeto de construção de escolas, um espaço reservado às bibliotecas. Ao fazer isso, levar em conta que uma unidade de informação não é meramente um apanhado de livros em um canto de uma sala, e, sim, um lugar organizado para se ter acesso e utilizar a informação, conforme interesse de alunos e professores.

\subsection{Equipamento da biblioteca escolar}

Considera-se como equipamentos os móveis e os instrumentos relativos ao tratamento da informação - como a catalogação, entrada e saída dos documentos para circulação - automatizados ou não, pois a realidade das bibliotecas no Brasil, nem sempre é de serem automatizadas.

Quanto à escolha dos móveis da biblioteca escolar, deve-se preferir aqueles que são de aço, por que proporcionarem maior durabilidade, e também por serem padronizados. Quanto às especificações dos mesmos, aconselha-se que o balcão de empréstimo tenha alturas variadas para atender às crianças menores e jovens; as mesas serem retangulares ou quadradas; as estantes serem planejadas de modo a aproveitar melhor o espaço (TAVARES, 1973).

Outros elementos citados por Tavares incluem como componentes dos equipamentos os "arquivos, caixas para folhetos, [bibliocantos], armários para guardar material de secretaria, quadro de aviso e painel para exposições" (1973, p. 34). A biblioteca deve possuir uma sala de entrada, com catracas e armários de guarda dos objetos dos leitores, bem como um guichê de informações gerais.

É importante que a biblioteca tenha estações de trabalho para os funcionários e para o bibliotecário.

Certamente, se a instituição educacional dispõe de recursos financeiros é 
interessante que esta adquira equipamentos de tecnologia digital, como computadores e impressoras, programas de computadores para gerenciamento de atividades e serviços da biblioteca, e tenha acesso a Internet. O uso da rede permitiu uma mudança nos serviços da biblioteca de um modo geral, por exemplo, divulgação "de informações sobre [a mesma], de novas aquisições, de atividades, orientações" (BICHERI, 2008, f. 130); melhorar a comunicação entre seus usuários, como na agilização de notificações quanto a serviços de devolução e reserva, e também com outras bibliotecas, através do correio eletrônico; possibilitou a implementação de redes bibliográficas e colaborativas.

Igualmente que a biblioteca disponha de equipamentos audiovisuais, como televisão e retroprojetor para execução de mídias, como videocassete, CDs, DVDs.

\subsubsection{O acervo escolar e sua organização}

O acervo é um dos aspectos relevantes de uma biblioteca seja de que natureza ela for. Neste contexto, estão envolvidos fatores, como: que materiais constituem o mesmo; sua formação e as diretrizes para tanto; e sua organização.

Pode ser definido o acervo como "o conjunto de coleções que, separadamente, são constituídas por tipo de publicação/documento (obras em geral, de referência, periódicos, folhetos; pastas e apostilas; audiovisuais, artefatos digitais/ eletrônicos, objetos instrucionais, entre outros)" (MACEDO, 2005, p. 318).

É compreendido por Cunha e Cavalcanti como o "conjunto de documentos conservados para o atendimento das finalidades de uma biblioteca: informação, pesquisa, educação e recreação [...]" (2008, p. 2).

No decorrer da história o ser humano utilizou-se de várias formas para o registro do conhecimento, que foram mudando com o tempo e de acordo com a 
tecnologia.

Conforme Abreu (2005, p. 29) na Antigüidade e até alguns séculos atrás, usou-se papiros e pergaminhos. Com o surgimento da imprensa outros suportes foram acrescidos como revistas, livros, e hoje se faz uso também da tecnologia digital e mídias audiovisuais para registro do conhecimento.

De acordo com os Parâmetros Curriculares Nacionais na biblioteca escolar deve haver diversidade textual, enfatizando que a aprendizagem da língua portuguesa deve ser de dois modos: o oral e o escrito. Neste documento, o ensino do idioma "prevê o uso intensivo de textos que circulam socialmente, em suportes originais", para que os alunos tenham "oportunidade de compreender os usos da escrita, em diferentes circunstâncias, observando suas várias funções e características" (apud ABREU, 2005, p. 30).

Afirma Carvalho ser necessário que uma biblioteca não somente possua um acervo de qualidade, mas também que haja interdisciplinaridade - integração mútua dos conteúdos - bem como, esteja alinhado aos objetivos da organização a qual está subordinada (1980, p. 198-199).

Com relação ao acervo, Tavares afirma que o material que a constitui deve ser predominantemente "de livros de consulta e de informação, livros de estudo e ensino, didáticos [...] e todos os demais que possam ser adquiridos e que atendam aos currículos escolares". Ainda é imprescindível que contenha em seu acervo materiais como "recortes, cartazes [...] material audiovisual" (1973, p. 23-24).

A autora cita que deve fazer parte da coleção do setor de referência, os seguintes materiais: enciclopédias, dicionários (gerais e específicos), atlas, almanaques, anuários, entre outros. Escreve Tavares que igualmente é preciso que a coleção seja composta de: "livros chamados de assunto ou elucidação: são 
aqueles que ensinam alguma coisa, de maneira informal, sob o aspecto criativo. Ao mesmo tempo [em] que narram uma estória, ensinam um assunto" (1973, p. 24).

Também devem fazer parte do acervo biografias, livros didáticos, material informativo, como "recortes de jornais e revistas, colecionados por assunto"; gravuras, e duplicatas das mesmas "para oferecer aos alunos e professores quando necessitarem fazer ilustrações em seus trabalhos escolares e para usar em cartazes"; material audiovisual, que a autora recomenda que tanto os itens adquiridos quanto os elaborados por professores, alunos e a equipe da biblioteca, devem pertencer à unidade de informação; periódicos a serem adquiridos precisam ser aqueles "que constituem fontes de ensino e servem para pesquisa" e menciona a autora que a biblioteca deve adquirir publicações periódicas, para o professor, específicas nas áreas de "educação, pedagogia e didática" que sejam oriundas do Brasil e de outros países (TAVARES, 1973, p. 25); entre outros.

Quanto aos materiais Macedo cita que é imprescindível que professor e bibliotecário conheçam seus tipos e funcionalidades dos itens informacionais "didáticos e de leitura, cultura e lazer" (2005, p. 315). Os materiais podem ser classificados, como (CARVALHO, 1980, p. 203-207; MACEDO, 2005, p. 317):

- Coleção de Referência: dicionários, enciclopédias, revisões, guias, bibliografias, resumos, catálogos, almanaques, anuários, biografias (MACEDO, 2005, p. 17; CARVALHO, 1980, p. 203-204);

- Coleção geral: constitui-se de "livros de assuntos [variados], manuais, textos metodológicos e didáticos, obras literárias, monografias" (MACEDO, 2005, p. 17);

- Periódicos: "publicações de caráter periódico são anais de congressos, revistas, boletins, jornais, [entre outros]", gerais e 
especializados;

- Coleção especial: contém materiais raros e folhetos;

- Multimeios ou audiovisuais: incluem "discos e fitas, filmes e vídeos, CD-ROM e disquetes, slides; [...] multimídias" (MACEDO); fontes cartográficas: mapas e atlas geográficos e históricos (CARVALHO).

\subsubsection{A relação acervo e educação infantil}

A educação infantil surgiu de algumas demandas da sociedade como o crescimento urbano, "participação da mulher no mercado de trabalho e mudanças na organização e estrutura das famílias". De acordo com Andrade por causa destes fatores foi instituída no Brasil, pela Constituição Federal de 1988, como dever do Estado a educação infantil. O Estatuto da Criança e do Adolescente enfatiza também este direito da criança; e igualmente a Lei de Diretrizes e Bases da Educação Nacional estabelece o direito e a relação entre a educação e as crianças da faixa etária entre zero e seis anos (ANDRADE, 2005, p. 56).

Um documento importante sobre o assunto é o Referencial Curricular Nacional para a Educação Infantil (elaborado pela Secretaria de Educação do Ministério da Educação). Ele contém diretrizes relevantes para educadores que trabalham com crianças nessa faixa etária. Também "aponta formas de construção da identidade e da autonomia das crianças pequenas, de sua aproximação com as diferentes linguagens, propiciando suas relações com os objetos do conhecimento" (ANDRADE, 2005, p. 55-56).

O Referencial é divido em duas partes principais: a primeira Formação Pessoal e Social e a segunda é Conhecimento de Mundo, que estão especificadas a seguir: 
orientações que visam a construir a identidade e autonomia das crianças [...] [engloba] temas como processos de fusão e diferenciação, a construção de vínculos, a imitação, o brincar, a linguagem, a apropriação da imagem corporal; [...] [na segunda parte apresenta uma sucessão] de conteúdos orientados para a construção das diferentes linguagens e para as relações com os objetos do conhecimento" (ANDRADE, 2005, p. 56$57)$.

A relevância desse documento para a biblioteca escolar se dá no sentido que a mesma poderá aplicar as diretrizes apontadas para orientar os educadores de crianças entre zero e seis anos.

A partir desse documento, pode-se fundamentar as atividades e os critérios para a escolha de suportes informacionais utilizadas na biblioteca para auxiliar na educação desses alunos, com a utilização de diversos gêneros literários (narrativo, épico, lírico, dramático e outros) e materiais variados (jornais, revistas, enciclopédias, dicionários, almanaques, entre outros).

No Referencial Curricular existe o tópico Natureza e Sociedade, que têm por assuntos os seres vivos; os fenômenos da natureza; objetos e processo de transformação; organização dos grupos e seus modos de ser, viver e trabalhar; os lugares e suas paisagens. É possível desenvolver os três primeiros assuntos

por meio da observação direta (cultivo de plantas; de pequenos animais e de fenômenos da natureza como a chuva, seca...) ou de forma indireta, através de materiais audiovisuais (fotografias e filmes). [Os suportes informacionais indicados para usar nesse bloco de conteúdos são] textos, mapas, filmes, depoimentos de pessoas, além das tradicionais enciclopédias e livros, [entre outros] (ANDRADE, 2005, p. 58).

Outros conteúdos como:

noções matemáticas podem ser ensinadas [...] com atividades que envolvem contagem oral, noções de quantidade, de tempo e de espaço e possibilidades associativas de objetos, desenvolvidas através de jogos e brincadeiras com crianças na faixa etária de zero a três anos. Dos quatro a seis anos, o conteúdo dessa área se organiza em três blocos: 'Números e sistema de numeração', 'Grandezas e medidas' e 'Espaço e forma'. Isso demanda uma variedade de jogos como dominós, baralho, jogos com pistas espaciais e outros que apóiem a aprendizagem da matemática (ANDRADE, 2005, p. 59). 
Com relação ao conteúdo de Arte, ela se encontra nos assuntos como "música, artes visuais e movimento (dança)" (ANDRADE, 2005, p. 59). Este conteúdo é considerado como relevante modo "de expressão e comunicação humanas, as artes criam um espaço prazeroso para a criança expressar a sua sensibilidade" (ANDRADE, 2005, p. 59). Os materiais indicados para as atividades de artes são "livros de arte, reproduções, revistas especializadas, CDs de canções e músicas diversas, vídeos de danças folclóricas e populares" (ANDRADE, 2005, p. $60)$.

Ao se falar em educação infantil é necessário lembrar que "a aprendizagem das competências lingüísticas básicas (falar, escutar, ler e escrever) é feita com base no texto. A leitura e a escuta de histórias" resulta no incitamento da atitude de curiosidade pelo livro e pelo interesse na leitura. Isso se dá, por meio da "utilização de textos bem selecionados, criativos, ricos e com ilustrações de qualidade" (ANDRADE, 2005, p. 57).

Com estes exemplos verifica-se que há uma necessidade específica de conteúdo e forma para cada uma das disciplinas que deverão conter numa biblioteca escolar, no que se refere à educação infantil. Igualmente, de criação de programas para atender às demandas e necessidades das crianças entre zero e seis anos, para que criança desde já aprenda como utilizar um espaço que irá fazer parte de sua vida por muito tempo. E deve-se atentar para o fato de não subestimálas por conta da sua idade, ao se escolher os documentos que irão utilizar na biblioteca. 


\subsubsection{Organização da informação na biblioteca escolar}

O tratamento da informação envolve atividades que irão representar descritivamente - por meios de códigos de catalogação, tematicamente classificação e indexação. Há também bibliotecas que elaboram catálogos de sua coleção, com itens como autor, assunto, para facilitar o acesso às estantes e, assim melhorar a recuperação da informação (MACEDO, 2005, p. 320).

Vianna menciona a questão da organização da informação na biblioteca escolar. A autora afirma que certas bibliotecas ordenam seus acervos por meio de classificações usando as cores e que isso pode ser prático momentaneamente mas também impede que os estudantes "conheçam formas consolidadas de organização de bibliotecas", na qual os mesmos irão se deparar mais tarde. Isso pode ser verificado na conduta dos estudantes quando entram na "universidade: muito deles desconhecem o funcionamento de bibliotecas e dos instrumentos que elas costumam elaborar para possibilitar a recuperação da informação" (VIANNA, 2005, p. 43).

Há instrumentos padronizados de classificação, catalogação e outros que tem como finalidade ordenar o acervo e recuperar a informação, utilizados na maioria das bibliotecas do mundo inteiro, por exemplo, a Classificação Decimal de Dewey (CDD) e a Classificação Decimal Universal (CDU).

As vantagens da utilização de sistemas de classificação padronizados são: possibilitar a descrição precisa de todos os tipos de documentos, "de forma que cada um dos itens que [compõem o acervo] possa ser identificado individualmente" e ser recuperado (VIANNA, 2005, p. 45); atualmente também são utilizados padrões de intercâmbio bibliográfico - por tornarem possível a troca de dados por computador - a catalogação cooperativa. O uso dos padrões citados irá permitir 
aos alunos que se familiarizem com essas normalizações. Certamente, será necessário que se faça algumas adaptações no caso da coleção destinado ao público infantil, lembrando que quando a criança entrar na fase da

\begin{abstract}
leitura permanente e de busca de informação para seus trabalhos escolares, ela terá de entender a organização dos materiais na biblioteca, a qual, se freqüentada sistematicamente e constantemente, levará o estudante a assimilar de forma natural os procedimentos necessários para explorar os materiais e as informações nela contida (Vianna, 2005, p. 46).
\end{abstract}

\title{
4.3.3.3 Desenvolvimento de coleções - o processo de seleção e aquisição
}

É extraordinário que a biblioteca escolar possua um plano escrito de desenvolvimento de coleções, pois um documento assim irá nortear as ações, com critérios e diretrizes, quanto ao que precisa ser incluído ou não no acervo.

Sobre a seleção e aquisição, deve-se ter delineados os objetivos da biblioteca, e o material que a compõe precisa estar alinhado com as "necessidades do aluno e professor" (TAVARES, 1973, p. 29).

É sugerido por Tavares, como princípios norteadores: a "preponderância de material informativo e didático; livros recreativos na proporção que não prejudique a aquisição do material específico aos objetivos da escola". Quanto à quantidade, a metade deve ser material informativo, consulta e estudo; $40 \%$ material didático e 10\% recreativo (1973, p. 29-30).

A autora supracitada alude ao fato de que é relevante que sejam feitas sugestões de compra por parte dos professores e também dos alunos. Da mesma forma, é indispensável que se atualize constantemente a coleção. De forma semelhante, é imprescindível a consulta a determinados materiais que irão auxiliar o bibliotecário a executar a seleção e a aquisição cada vez melhor, como "as bibliografias, comentários em colunas especializadas de revistas e jornais, 
catálogos de editores", site de editoras e livrarias, entre outros. Deve haver colaboração com opiniões de pessoas competentes acerca dos livros e outros materiais informacionais relativos ao acervo. Igualmente, é significante o empenho do bibliotecário para fazer o que estiver ao seu alcance para adquirir os melhores itens informacionais para a biblioteca escolar (TAVARES, 1973, p. 30).

Devem-se levar em conta os seguintes aspectos quando da elaboração de uma política de formação de coleções, segundo Carvalho (1980, p. 199):

- necessidade do currículo atual;

- interesses individuais dos alunos, baseados na idade, nível de aprendizagem, habilidades e experiência anterior dos mesmos;

- veiculação aos professores de informação profissional;

- qualidade e adequação do material disponível no mercado e [...]

- verba.

Para Macedo (2005, p. 318-319) essa é uma tarefa de natureza não somente seletiva, bem como de avaliação e que precisa considerar os seguintes fatores:

- O tipo da biblioteca e seus objetivos educacionais e a relação com seu público-alvo (biblioteca escolar para o ensino básico, prestando serviços a professores e alunos, em princípio; conhecimento prévio das necessidades e interesses dos grupos de usuários, do ensino-aprendizagem; adequações e conveniências do usuário: idade, idioma, estilo).

- Os assuntos e o nível das publicações (matérias curriculares e interesses de ensino e aprendizagem).

- O tipo de documento (dos livros aos multimeios; necessidades momentâneas ou interesses permanentes de um conjunto de usuários; o tipo de suporte de documento para torná-lo mais forte em alguns pontos; balanceamento e estágio de desenvolvimento das coleções; atualização de áreas; inovações; intercâmbios com outras bibliotecas).

- A relação de quem vai selecionar (conhecimento do acervo, dos programas e bibliografia das matérias curriculares, interação com a comunidade escolar e o mercado editorial).

Esses fatores possibilitarão, conforme Carvalho, a indicação "de instrumentos bibliográficos aconselháveis para a seleção, [definição] de critérios para duplicação de títulos, programas cooperativos, avaliação e descarte" (1980, p. 199). Instrumentos esses, que não se limitam a ser bibliográficos, mas também 
podem ser formulários e estatísticas, estudos de usuários e de circulação de documentos, sugestões dos professores e alunos, catálogos de editoras, entre outros.

Macedo (2005, p. 319) corrobora neste sentido, e menciona que é preciso operacionalizar esse processo, com a criação de uma comissão.

Carvalho afirma que é interessante a existência de uma comissão que tenha a participação de alunos e seus pais, professores e bibliotecário(s). Este último coordena o processo e dá a palavra final quanto à seleção dos materiais, pois se encontra numa posição estratégica, porque tem uma visão abrangente da coleção, conhece as especificidades de cada disciplina e as peculiaridades dos usuários, segundo a autora (1980, p.199-200). Garcez e Blattmann mencionam que os professores pouco tem sugerido obras para a coleção da biblioteca escolar (2005, p. 328), por isso é importante a participação destes profissionais nas atividades de seleção.

Outros aspectos relacionados com a política de desenvolvimento de coleções são os assuntos, a clientela e a verba.

Sobre os assuntos é recomendado que se incorporem todas as áreas do conhecimento, se orientando pelo currículo que pode enfatizar mais umas áreas que outras (CARVALHO, 1980, p. 207).

Relativo à clientela, afirma Carvalho, que é importante pensar nos seguimentos que serão servidos pela biblioteca, sendo o foco principal os alunos, em seguida professores e funcionários da unidade de informação. Em relação aos primeiros, afirma a autora que se deve considerar que geralmente há diferentes níveis em uma mesma turma ou série, existem alunos acima da média, dentro da média e abaixo; é imprescindível estimular aqueles com pouco ou nenhum hábito 
de leitura, inserir documentos com ilustrações criativas e chamativas em locais estratégicos com o fim de levá-los ao gosto pela leitura, como livros de ficção e revistas em quadrinhos (1980, p. 210). Quando se pensar no professor durante a fase de seleção de materiais, é necessário levar em conta a atualização dos documentos, o enfoque que cada profissional quer dar de sua área de atuação, também itens informacionais em outras línguas.

Quanto à verba é consenso dos estudiosos, que a mesma tem grande influência sobre a qualidade da coleção. Porém, Carvalho cita que é possível obter obras de qualidade e ter um acervo satisfatório com criatividade e de forma racional, mesmo com orçamento reduzido (1980). E sugere como forma de remediar esse problema orçamentário inserção de documentos doados, certamente com critérios pré-estabelecidos para não acarretar em material não utilizado.

Martucci (2005, p. 323-325) enfoca a questão da verba nas escolas públicas, pois as instituições de ensino particulares se encontram em vantagem sobre àquelas. Esta afirma que é necessário ao biblioteconomista entender o funcionamento das leis orçamentárias do Brasil como o Plano Plurianual, a Lei de Diretrizes Orçamentária que vão definir as verbas para cada estado e município, ou, ao menos, entender da política orçamentária local. E cita também o fato de que em alguns municípios e estados é o Secretário Municipal que cuida de recursos financeiros que serão destinados à escola e conseqüentemente à biblioteca.

E mais, em determinados lugares existe a participação do diretor no processo de decisão da política orçamentária do estado ou município. A autora recomenda é significativo ter uma boa comunicação com o diretor da escola neste caso. Também é válido existir uma boa comunicação e "jogo de cintura" com 
fornecedores e editoras, para negociar a obtenção de obras (MARTUCCI, 2005, p. 324). Assim, constitui-se imperioso uma iniciativa em conjunto do bibliotecário com professores, responsáveis pelos alunos e principalmente o diretor para lutar por recursos que otimizem o acervo da biblioteca escolar.

Diante dos aspectos relacionados no tópico relativo ao acervo da biblioteca da escola e sua organização, observa-se que é imprescindível tratar dos materiais que farão parte do mesmo, em que suportes estarão eles, se em papel, se em meio eletrônico, audiovisual, multimídia.

É preciso estar atento também ao tratamento da informação, quanto aos mecanismos descritivos e temáticos de organizar esses materiais, pois eles definem como será recuperada a informação.

Da mesma forma, um fator a se considerar é a coleção destinada às crianças e sua adequação quanto à organização, com o objetivo de estimular o quanto antes o hábito de ler.

Enfim, para tudo isso é válido a criação de uma política de desenvolvimento de coleções, por que ela irá definir como se deve formar o acervo, quais os pontos principais a serem levados em consideração no momento de escolha do documento, de descarte, de programas como intercâmbio, o público-alvo da política, entre outros.

\subsubsection{Pesquisa escolar}

Nos anos de 1960 já se praticava a pesquisa escolar no Brasil, de maneira informal, nas instituições de ensino privado, devido a algumas correntes como as da Escola Nova e Piagetiana propagarem que o ensino não deveria ser somente centrado no professor e sim no aluno e em métodos que o levassem ao 
pensamento crítico (BICHERI, 2008, f. 60).

Também por observarem que a pesquisa escolar poderia contribuir de forma significante quanto ao processo de ensino-aprendizagem (BICHERI, 2008, f. $60)$.

Apenas a partir da década de 1970, foi implementada a pesquisa escolar de caráter obrigatório, nos colégios públicos de ensino fundamental e médio, com o advento da Lei de Diretrizes e Bases (LDB). Porém não foi previsto em seu conteúdo infra-estrutura e condições para que professores e alunos pudessem se beneficiar com tal atividade. Os professores não dispunham de disciplinas em seus currículos que tratassem do tema, tanto no magistério quanto na graduação (BICHERI, 2008, f. 60). Igualmente, não se previu o local adequado para os alunos coletarem as informações necessárias ao trabalho de pesquisa, local esse representado pela biblioteca (SILVA, 1995, p. 47).

A pesquisa pode ser conceituada como:

1. Ato ou efeito de pesquisar. 2. Indagação ou busca minuciosa para verificação da realidade; investigação, inquirição. 3. Investigação e estudo, minudentes e sistemáticos, com o fim de descobrir ou estabelecer fatos ou princípios relativos a um campo qualquer do conhecimento: pesquisa química, pesquisa arqueológica (FERREIRA, 1999 apud BICHERI, 2008, f. $57)$.

Há tipos diferentes de pesquisa, é importante salientar de acordo com Demo (1993, p. 97, apud BICHERI, 2008, f. 56) "que a pesquisa é vista"

sob dupla face complementar, numa como princípio científico, noutra como princípio educativo. No espaço da educação básica, prepondera a segunda face, porque não está em jogo produzir ciência propriamente, mas construir a metodologia do aprender a aprender. Pesquisa ressalta a sua pretensão educativa, emergindo como estratégia de formação, âmago da pedagogia, dentro da didática (grifo de Bicheri).

Existe um consenso entre educadores de que a pesquisa escolar é de suma importância, que "é uma excelente estratégia de aprendizagem, pois permite maior participação do aluno nesse processo, o que o leva a construir seu próprio 
conhecimento" (ABREU, 2005, p. 25).

Subentende-se por meio da literatura que alguns objetivos da pesquisa escolar podem ser definidos como fixar a aprendizagem, aprofundar o conhecimento sobre determinados assuntos. Têm certas funções tais quais, levar o estudante à independência no estudo, ao desenvolvimento do pensamento crítico e o gosto pela leitura (MORO e ESTABEL, 2005, p. 1 apud BICHERI, 2008, f. 58).

Verificam-se também através da literatura quais indivíduos estão envolvidos neste processo, por exemplo, o estudante e seus parentes, o professor e o bibliotecário.

Um painel realizado pelo Grupo de Estudos sobre Biblioteca Escolar da Escola de Ciência da Informação da Universidade Federal de Minas Gerais com professores e bibliotecários mostrou que quando é solicitado aos alunos realizar a pesquisa escolar, muitos copiam partes de enciclopédias e da Internet. Os bibliotecários reclamam que não tem um conhecimento prévio do assunto requerido aos alunos e que não há condições para que os profissionais se preparem de forma apropriada para fazer o atendimento àqueles. Outro fator percebido é que os alunos não têm noção do que pesquisar, por que "os professores não orientam efetivamente e não estabelecem com clareza, os objetivos do trabalho". Além disso, os pais pensando estar ajudando, fazem o trabalho que foi pedido aos estudantes (ABREU, 2005, p. 26).

Vale destacar também o relato de Bicheri que durante 17 anos atuou como bibliotecária escolar e pôde observar o comportamento de alunos, professores, parentes dos alunos e o do bibliotecário, mostrado pelo quadro a seguir: 


\begin{tabular}{|c|c|}
\hline \multicolumn{2}{|r|}{ Como eram as pesquisas no primeiro ano de atividade da bibliotecária } \\
\hline Alunos & 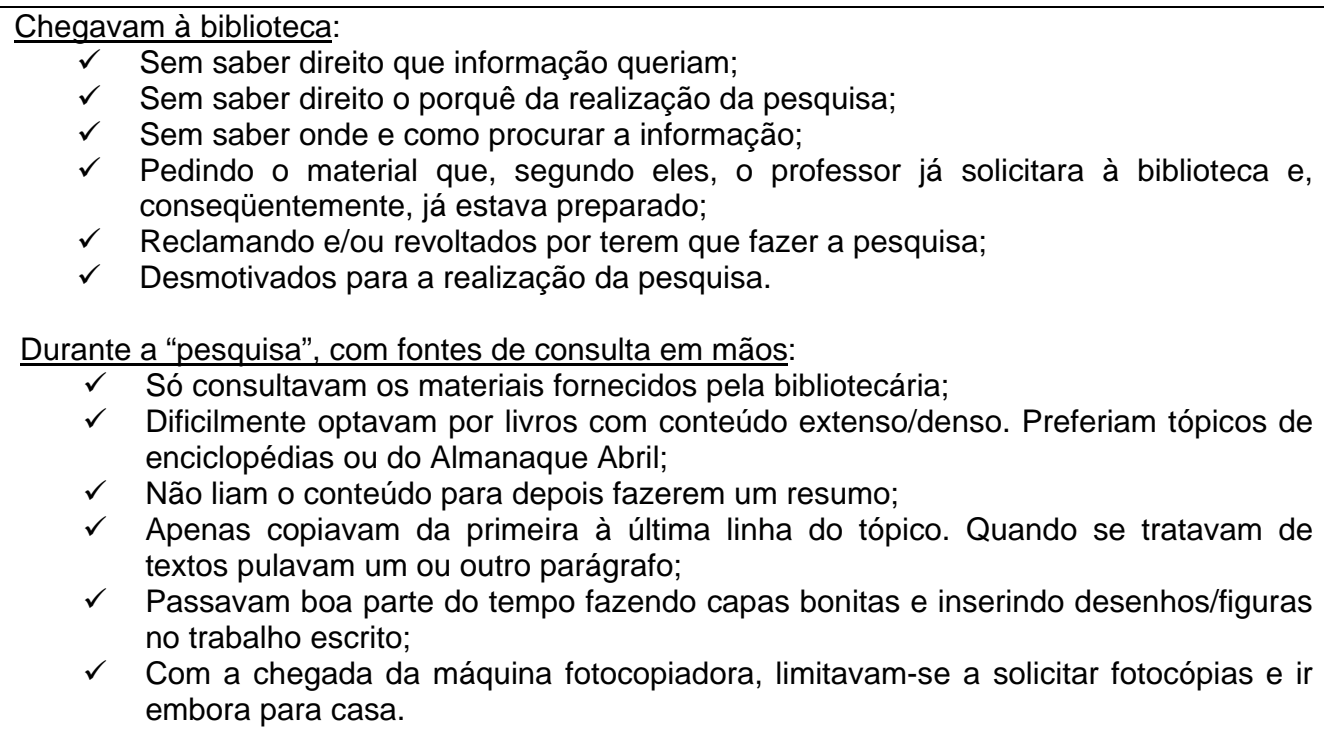 \\
\hline $\begin{array}{l}\text { Parentes de } \\
\text { alunos }\end{array}$ & 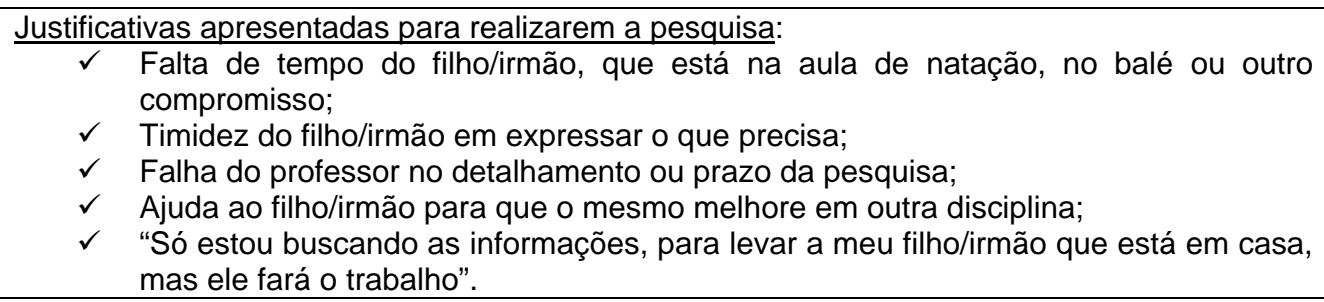 \\
\hline Bibliotecária & 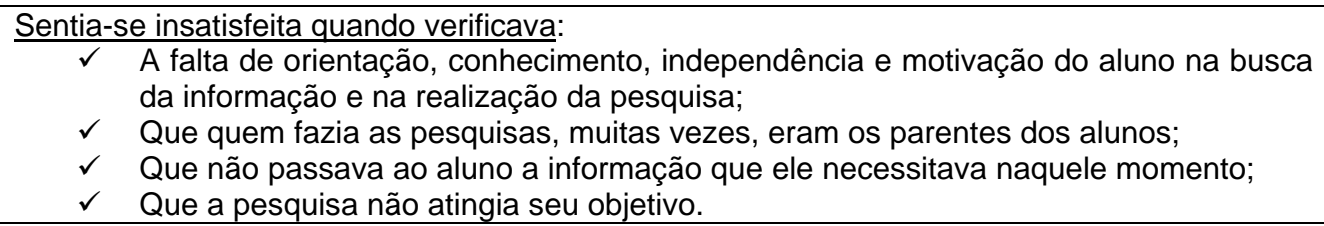 \\
\hline Professores & 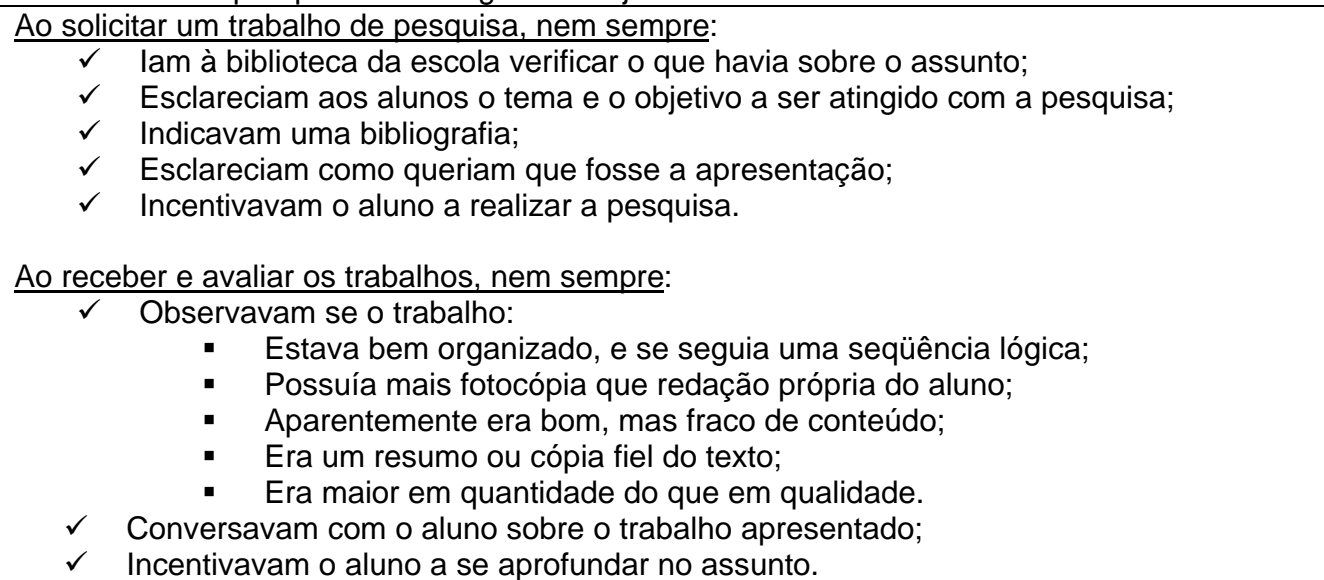 \\
\hline
\end{tabular}

Fonte: BICHERI (2008, f. 63-64).

Figura 4 - Como eram as pesquisas no primeiro de atividade da bibliotecária.

A partir deste quadro a bibliotecária propôs algumas alternativas para que essa situação tivesse uma solução. Então, a mesma procurou os professores e relatou a estes a forma na qual se comportavam os estudantes quando da 
realização da pesquisa. Realizou alguns encontros com os professores que estavam interessados e, juntos discutiram e implementaram atividades. Afirma que não teve adesão total daqueles, mas que obteve alguns resultados bastante significativos.

Algumas das iniciativas tomadas por Bicheri que podem ser citadas seguem: os professores compareceram à biblioteca para conhecer o acervo relativo à sua especialidade e indicaram obras que consideravam importantes estar no acervo ou precisavam ser desbastadas; a bibliotecária elaborou cartazes para orientar os alunos quanto à pesquisa, à consulta a catálogos, à utilização de livros, enciclopédias e periódicos; foram repassadas instruções aos alunos quanto ao procedimento de utilização de normas da ABNT; organizaram-se visitas periódicas das turmas à biblioteca. Quando a escola adquiriu computadores com acesso a Internet, esta também fez cartilhas para orientar os alunos quanto ao uso da informação na rede, entre outras. E isso foi refletido no comportamento de alguns alunos que passaram a ter motivação e interesse em efetuar a pesquisa escolar (2008, f. 65-67).

Conclui então Bicheri (2008) que é extraordinário que os professores conheçam a biblioteca, o acervo relacionado à sua área de conhecimento e verifiquem o material disponível para os trabalhos que solicitarem aos alunos, e menciona que eles próprios necessitam ser pesquisadores.

A autora menciona também que é relevante que os professores expliquem aos alunos a finalidade e a razão de se elaborar a pesquisa; deixar explícitos os critérios para avaliação e apresentação da pesquisa; enfatizar que o importante é a qualidade e não a quantidade; igualmente o que é imprescindível pesquisar acerca do tema solicitado; estar disposto a sanar as dúvidas oriundas da pesquisa; instigar 
e motivar ao alunos para que busquem soluções aos problemas suscitados pelo tema do trabalho escolar. Para que se diminua a prática da cópia (Bicheri, 2008, f. 76).

Sobre a relação família e pesquisa, é possível perceber o papel que a mesma desempenha neste contexto. Como pode ser mostrada por Bicheri, uma boa parte das vezes são os parentes que realizam a pesquisa, em muitas situações pode-se dizer que por temerem que o aluno não vá alcançar uma nota adequada. Segundo a autora, porque se preocupam como o filho ou irmão se colocar ou não no mercado de trabalho, fazendo assim que o mesmo não obtenha independência e tendo efeito contrário ao que os parentes desejam para seus filhos, netos, entre outros. Assim sugere que os responsáveis pelo estudante participem de sua vida escolar, não tomando a responsabilidade que não lhe cabe, como fazem, às vezes, realizando as pesquisas no lugar do estudante, pensando estar auxiliando-o (BICHERI, 2008, f. 74-75).

Além disso, enfatiza Macedo que os educadores devem indicar o local adequado para os alunos realizarem a pesquisa, por exemplo, a biblioteca escolar este local apropriado, para que estes não desperdicem seu tempo procurando em locais que não são específicos para tal atividade. E sugere que não havendo a biblioteca na escola, orientar adequadamente quanto aos materiais mais apropriados para a realização da pesquisa e onde encontrá-los. Menciona a estudiosa que ocorreram casos de alunos do ensino médio e fundamental procurarem bibliotecas universitárias ou especializadas para a efetuação de seus trabalhos escolares (2005, p. 81 e 84$)$.

Corrobora nesse sentido Tavares (1973, p. 39-43), ao fazer menção, a partir de um trecho extraído da publicação "O livro didático e sua utilização em classe", 
de aspectos relevantes para a pesquisa escolar e, que o professor e o bibliotecário precisam estar atentos, como o que deve ser aprendido pelo aluno e de que forma o mesmo vai aprender um assunto, que fontes consultar e como consultá-las.

Assim, Tavares afirma que é preciso que o professor estabeleça objetivos, com a finalidade de que estes norteiem o que precisa ser apreendido pelo aluno. Quanto à maneira pela qual o aluno apreende a informação, é imprescindível que ele seja levado a reconhecer os pontos principais do estudo e que se ensine ao aluno a questionar a informação localizada, qual a finalidade dessa e a razão de utilizá-la. Induzir o aluno a questionar se a informação é válida dentro de determinado contexto (TAVARES, 1973, p. 40-41).

Para que esse não percorra por "atalhos interessantes [...] e depois [se pergunte]: 'e agora, onde estou? pra que lado devo seguir" utilizando-se assim de dados que não são válidos e nada contribuem com o tema, ao menos naquele momento, ou problematizam ainda mais e trazem confusão quanto a que caminho seguir (SILVA, 2009).

Sobre as fontes de informações é significante lembrar que se deve explicar ao estudante a respeito dos tipos de cada uma das fontes, mostrar-lhe suas características, quais finalidades cada uma tem, como localizá-las, é necessário também que o aluno compreenda a organização de cada suporte e saiba interpretar as informações contidas nele (TAVARES, 1973, p. 43-44). E isso pode ser feito tanto pelo professor quanto pelo bibliotecário.

É indispensável citar quanto à figura do bibliotecário:

[que este] deve contribuir para que os usuários sejam competentes e independentes na realização de consultas nas diversas fontes de informação; na localização do assunto desejado identificando e compreendendo as principais idéias do texto; relacionando-as com outros assuntos/textos correlatos e verificando sua validade e pertinência, na elaboração de resumos e conclusões com base nos textos lidos. 
Também deve orientá-los quanto ao uso de citações, referenciando as fontes consultadas, evitando o plágio e respeitando o direito autoral. Capacitar gradativamente os alunos no uso das normas da ABNT: citações, resumos, referências, apresentação de trabalhos, e outras informações que enriqueçam os trabalhos (BICHERI, 2008, f. 83).

Ainda sobre a figura do bibliotecário nas etapas da pesquisa escolar é válido destacar o que Macedo afirma a respeito, que este profissional precisa estar apto a lidar com as diferentes personalidades dos leitores e compreender a sua linguagem, para fornecer o material do qual o aluno irá elaborar seu trabalho (2005, p. 82).

Carol Kuhlthau (apud ABREU, 2005, p. 26) que fez uma pesquisa minuciosa a respeito do tema, afirma que "a pesquisa escolar como estratégia de aprendizagem baseada no questionamento, deve possibilitar ao aluno desenvolver habilidades de escolha de temas e de fontes de informação e de utilização de recursos que ajudem a clarear as suas idéias, como [...] esquemas, tabelas e gráficos".

Da mesma forma, é preciso que o aluno esteja familiarizado com a biblioteca, saiba utilizá-la, e saiba também como consultar as fontes de informação e os materiais. Se for exigido ao aluno trabalho escrito é necessário que conheçam as normas de citação e referência, "organização e apresentação; ou se for uma apresentação oral que saibam utilizar recursos audiovisuais e que ele esteja preparado para falar em público. Dessa maneira ele desenvolve conhecimentos que vão além do tema do trabalho" (ABREU, 2005, p. 27).

Abreu afirma que uma questão a se levar em conta é que professores e bibliotecários devem ter em mente que a pesquisa escolar não é algo, que acontece de uma vez só, mas que é um processo, e este processo precisa ser trabalhado para que o pensamento do aluno acerca do assunto mude. O autor 
observou também que "só serão alcançados resultados positivos dessa estratégia de aprendizagem se a escola investir, sistemática e continuamente, em programas de desenvolvimento de habilidades informacionais, que deverão iniciar-se cedo na vida da criança" (2005, p. 27).

É importante reconhecer o valor da pesquisa para o processo de ensinoaprendizagem, como sendo mais um dos recursos de aprendizado para esse processo. Igualmente, entender quais são as funções e objetivos dessa, que indivíduos estão presentes neste contexto como: alunos, professores, bibliotecários e os familiares dos alunos e o papel dos três últimos sobre este processo e da mesma forma a influência sobre o aluno que é o principal beneficiário da pesquisa.

É válido destacar também que a biblioteca escolar tem papel significativo, pois ela irá prover os recursos informacionais adequados e variados para a pesquisa.

\subsubsection{Pesquisa escolar e Internet}

É relevante fomentar o uso de tecnologias de informação, como é muito discutido na área de Biblioteconomia e na Sociedade da Informação e do Conhecimento. As tecnologias da informação e comunicação cada vez mais se fazem presentes na sociedade, propiciando, por exemplo, a existência da Internet. A relevância do seu uso se mostra na educação à distância, na catalogação cooperativa - por meio do intercâmbio de dados eletrônicos -, na agilização de processos técnicos.

O acesso a Internet é igualmente importante, pois é uma ferramenta que tem se mostrado bastante útil na educação.

Vianna (2005, p. 37) afirma que durante três anos (entre 1999 e 2002) o 
governo britânico investiu setecentos milhões de libras - em torno de dois bilhões de reais - em equipamentos para que as escolas tenham conexão com a Internet; e destinou mais de duzentos e trinta milhões de libras (aproximadamente novecentos e trinta milhões de reais) para fazer o treinamento de professores e bibliotecários a fim de utilizarem a tecnologia citada.

A realidade brasileira, no entanto, é bem diferente, uma vez que o governo brasileiro investiu apenas três por cento do total investido pelo governo britânico. Vianna menciona também que o governo britânico investiu em treinamento dos profissionais para utilização da tecnologia citada. Conforme a autora, a intenção dos dados mostrados não é fazer uma comparação entre a verba aplicada, e sim saber como um país lida com essa situação (2005, p. 37).

Com o surgimento da Internet e sua utilização cada vez maior, há também uma necessidade para que as pessoas possuam letramento digital, o que significa que uso desta tecnologia não deve estar limitado somente ao saber usar os equipamentos e programas de computadores, mas também ter aptidões para interpretar documentos que contenham em si mesmos vários recursos de texto, de som e de imagem (BUZATO, 2005, p. 1; apud BICHERI, 2008, f. 128).

É preciso atentar para o fato de que na rede as informações encontradas não são selecionadas e nem tem critérios para tanto. Além disso, existem sites "que não apresentam qualquer contribuição para a formação do aluno" (VIANNA, 2005, p. 38).

Dessa forma, a inquietação da biblioteca é adequar e selecionar a informação oriunda da Internet e, instituir critérios ou fazer avaliação ponderada para que não haja a incorporação de sites e páginas da rede na biblioteca que contenham informações de caráter tendencioso, preconceituosas e não confiáveis 
(VIANNA, 2005, p. 38).

Vianna (2005, p 39) aponta algumas alternativas para se certificar do "acesso a informações confiáveis" como o acesso supervisionado que não é tão prático; orientar as crianças com o propósito de torná-las consciente em relação às informações da rede; criar "intranets nas escolas" (VIANNA, 2005, p. 39), possibilitando à instituição de ensino que escolha os sites orientados à educação do aluno.

A questão, então, se mira na maneira, pela qual a seleção dos sites é feita e, refere-se, por exemplo, à atualização: "acréscimo e eliminação de sites, estabelecimento de novos links [...], manutenção da rede interna constantemente afinada com os programas escolares" (VIANNA, 2005, p. 38).

O projeto Ensinando Geografia na Web é um exemplo do que foi mencionado, pois a partir de normas de avaliação fixadas para os livros desse campo, adaptaram-se essas normas "ao meio eletrônico, gerando uma lista com diversas perguntas acerca do conteúdo, autoria, aspectos técnicos, atualização e apresentação dos sites". Essa lista pode ser aproveitada para outras áreas do conhecimento, por exemplo, permitindo que se opte por informações de valor que tenham "um impacto positivo no processo de aprendizagem" (VIANNA, 2005, p. 40).

Além disso, numa pesquisa realizada por estudiosos do Grupo de Pesquisa sobre Biblioteca Escolar da Escola de Ciência da Informação da Universidade Federal de Minas Gerais, mostrou que a Internet não é uma ferramenta muito utilizada como recurso de aprendizagem, como afirma Carvalho (2005, p. 33). Os resultados desta pesquisa indicaram que de um total de 372 estudantes da rede particular de ensino de Belo Horizonte, em Minas Gerais, da primeira à oitava série 
(de sete a dezesseis anos) (CARVALHO, 2005, p. 33-35):

- $25 \%$ usam a rede em recinto escolar e $75 \%$ a utilizam no meio doméstico (em domicílio de parentes, amigos, na própria casa e escritório dos pais). Em relação a esse quesito, professores e bibliotecários não exercem influência a respeito do conteúdo acessado pelos alunos, e, sim os amigos, colegas e irmãos;

-Alunos têm bastante independência para usar a Internet, somente 5,4\% deles pedem freqüentemente auxílio para utilizá-la, os menores pedem aos pais e outros familiares, e, os mais velhos aos amigos. De novo não existe participação significativa de professores e bibliotecários quanto a esse fator;

- Com relação aos trabalhos escolares foi constatado que o ato de copiar e até mesmo imprimir o conteúdo da Web - entregando o material impresso da mesma maneira que foi encontrado na rede ao professor - é algo feito com freqüência. Cerca de $45 \%$ dos alunos copiam o conteúdo pesquisado; entre os menores essa situação ocorre com maior freqüência, em torno de 23\%; os mais velhos tem a preocupação de ler e resumir o conteúdo que foi encontrado, sendo que $50 \%$ deles afirmam isso;

- Somente sete por cento usam a Internet como recurso único para efetuar a pesquisa escolar;

- Os alunos têm uma visão bastante positiva da Internet e "manifestam [...] grande expectativa por uma maior disponibilidade do uso da Internet na biblioteca da escola" (CARVALHO, 2005, p. 34);

- Dentre os estudantes, 53\% não somente se preocupam com o conteúdo pesquisado, mas também com a "organização, os custos, aspectos técnicos [e alguns itens como] autor, data e número de visitantes" (CARVALHO, 2005, p. 35);

- Outros dados percebidos são que os mecanismos de busca são constantemente 
utilizados como Cadê, Uol, Yahoo e outros.

Segundo Carvalho (2005, p. 35) atualmente as escolas estão implantando laboratórios de acesso a Internet e as bibliotecas já estão utilizando esse recurso como meio de auxílio ao ensino.

Para que a Internet tenha efeito cada vez mais positivo é necessário que seja feito um planejamento sólido de "ações pedagógicas" (CARVALHO, 2005, p. 36) procurando diminuir ou mesmo eliminar certos comportamentos como a cópia de documentos nos trabalhos escolares e para isso o bibliotecário exerce o papel fundamental de mediador desse processo (CARVALHO, 2005, p. 36).

Bicheri afirma que é necessária ao bibliotecário a atualização permanente nessa área de tecnologia da informação. Que aos conhecimentos tradicionais é possível acrescentar alguns conhecimentos referentes a:

softwares, hardwares, mídias, saber pesquisar na rede, conhecer e fazer uso dos recursos tecnológicos. Não conhecer só a máquina eletrônica e seus mecanismos, mas também ter conhecimento de linguagem/termos específicos de cada área/disciplina das quais são desenvolvidas pesquisas, bem como dominar outros idiomas (inglês, espanhol,...) (2008, f. 131).

Ainda a respeito do bibliotecário, Bicheri menciona que mesmo que a Internet tenha proporcionado às pessoas uma independência quanto ao acesso e ao uso das informações, uma boa parte necessita de auxílio deste profissional na identificação, seleção dos recursos informacionais.

Sobre a utilização da Internet na pesquisa é importante destacar que por meio da rede foi possibilitado o desenvolvimento de habilidades pelo aluno ao elaborar estratégias de buscas para localizar a informação, o compartilhamento de informações, o acesso mais rápido e maior a uma diversidade de recursos informacionais (MORO; SABARDINI; ESTABEL, 2004, p. 8), como é possível 
encontrar na rede dicionários, enciclopédias, periódicos e outros materiais eletrônicos.

Da mesma forma, proporcionou ao bibliotecário a transferência de competências utilizadas nos materiais informacionais convencionais para o ambiente virtual e que se encontram num lugar de destaque como mediador da informação (CAMPELLO et al, 2000, p. 20).

É possível constatar que a Internet é mais um instrumento que complementa aprendizagem do aluno, da mesma forma verifica-se a figura do bibliotecário como mediador neste processo de busca da informação em ambiente virtual, auxiliando o estudante na seleção e utilização desta tecnologia, bem como o professor também é ator importante neste cenário.

E a família que, às vezes auxilia no trabalho escolar do aluno conforme pesquisa do Grupo de Estudos em Biblioteca Escolar, mas que deveria entender como proporcionar a independência ao aluno. Para tanto é necessário que houvesse maior participação dos responsáveis na vida escolar dos estudantes.

Observa-se também que apesar da rede ter permitido uma independência por parte razoável dos indivíduos quanto ao acesso às informações, alguns ainda necessitam da mediação - anteriormente citada neste documento.

Enfim, constata-se que os bibliotecários precisam estar constantemente atualizados quanto às novas tecnologias e formas de organização de documentos encontrados na Internet, em um ambiente cada vez mais repleto de informações de diferentes tipos e qualidades. 


\subsubsection{Biblioteca e leitura}

É relevante o papel da biblioteca da escola, no que diz respeito à formação de leitores, pois, esta se constitui em um instrumento de estímulo ao hábito de leitura, de forma que o aluno irá aprender na unidade de informação a consultar as fontes de informação e como consultá-las, e a partir daí necessitará igualmente de apreender essa informação consultada, conforme afirmam estudiosos.

Menciona Polke que no ensino tradicional o foco era o professor e as informações transmitidas em sala de aula. E questiona a partir do momento em que o foco da educação mudou e passou a ser o aluno com suas peculiaridades e interesses, se a escola tratou de atribuir tarefas como a leitura e a compreensão de textos, solução de problemas múltiplos, por meio da "consulta bibliográfica [até mesmo de] representações gráficas" (1973, p. 62-63). Logo, pode-se inferir que a biblioteca é o local apropriado para executar essas tarefas, pois o aluno irá encontrar suportes informacionais de diversas naturezas.

Um exemplo de atividade relevante, a qual propulsiona o gosto pela leitura é a Hora do Conto, que pode ser combinada às atividades como filmes e estórias já conhecidas do público infantil, por exemplo, para que as crianças se sintam motivadas a ler as estórias nos livros (POLKE, 1973, p. 70).

Menciona ainda a autora, que é extraordinário planejar atividades e programas de leitura, por parte do professor e do bibliotecário, e são igualmente necessárias "criatividade e imaginação" de ambos, para "contribuir na formação desse hábito". Assim, se cedo o indivíduo for estimulado a ter prazer pela leitura, este hábito Ihe será de grande valor, enquanto estiver sendo educado formalmente e depois que terminar essa educação (1973, p. 70-71).

A biblioteca escolar é o lugar propício para sanar necessidades e interesses 
de leitura e que vai aproximar a sala de aula do aluno, por meio de uma gama variada de informação que possibilitará a formação do futuro leitor (POLKE, 1973, p. 60 apud VÁLIO, 1990, p. 19).

Bamberger (1977, apud VÁLIO, 1990, p. 19), renomado especialista na área de leitura em estudo realizado sobre leitura - num contexto mundial - a pedido da UNESCO, revelou que a idade ideal para se incutir o hábito de leitura em crianças, seria na idade de 8 a 13 anos. E que nesse período de vida, elas demonstram um desejo maior de ler e ao mesmo tempo "disposição para freqüentar bibliotecas". Observa-se dessa forma, que é mais uma autora, a qual enfatiza que o desenvolvimento do gosto pela leitura deve ser criado desde cedo.

Mostra mais uma vez, a importância da biblioteca escolar nesse processo, por exemplo, o sucesso para se assimilar novos dados e informações é feito pela maneira na qual se aprende. Por meio da coleção da biblioteca complementa-se a aprendizagem do assunto ensinado em sala de aula, e o modo de entender esse assunto está relacionado pela maneira como se utiliza a informação encontrada pela biblioteca da escola, por meio de periódicos, livros, enciclopédias, mapas, e outros.

Outro ponto, é que o aluno orientado pelo professor e o bibliotecário tem possibilidade de desenvolver mais e mais a capacidade "de formular questões, encontrar fontes de informação e selecionar, organizar e apresentar essas informações". Além disso, essas atividades constituem-se em um treinamento para a vida futura profissional e como cidadão que precisarão utilizar a informação (VÁLIO, 1990, p. 20-21).

A importância da leitura no processo educativo, a maneira pela qual se dá atualmente a formação de leitores e a participação da biblioteca neste processo, é 
questionada por Carvalho (2005, p. 21).

Conforme Perrotti (apud CARVALHO, 2005, p. 21), perito em estudos sobre a leitura, o assunto acerca da formação de leitores está relacionado a dois fatores: primeiramente "ao tratamento dado à criança", onde esta não é percebida como um "sujeito da cultura, capaz de criar e reelaborar informações e experiências dentro do processo educativo"; depois quanto ao "acesso ao livro e à leitura", que "implica na existência de uma boa escola, biblioteca funcionando de verdade, sob a direção de um bibliotecário habilitado, [...] acesso a boas fontes de informação" (2005, p. 22), e a participação de um professor que entenda a necessidade da presença da biblioteca no processo de ensino-aprendizagem.

Além disso, menciona Carvalho que algumas pesquisas mostram que existem políticas de promoção à leitura, as quais ainda acreditam que o importante é ler, seja o que for, como: atitudes de "colocar o livro na mão da criança a qualquer custo". Perrotti afirma (apud CARVALHO, 2005, p. 22) que ao se criar programas de incentivo à leitura para jovens e crianças é preciso que elas "tenham um quadro de referências culturais compartilhadas", isto é, fatos e coisas, os quais estejam relacionados ao seu cotidiano, ao meio no qual se situam, para que o ato de ler faça sentido em suas vidas.

Para que a biblioteca seja um local de formação de leitores críticos, é necessário, segundo Carvalho (2005, p. 22-23) que ela possua:

\footnotetext{
uma coleção de livros, e outros materiais, bem selecionada e atualizada; um ambiente físico concebido como espaço de comunicação e não apenas de informação, que leve em conta a corporalidade da leitura da criança e do adolescente, isto é, seus modos de ler; e por último [...] a figura do mediador [...] este deve estar preparado para o confronto sempre renovado com a criança e o jovem através da literatura, sem cobranças mecânicas de compreensão do texto lido e sem fórmulas rígidas de indicação por idade (CARVALHO, 2005, p. 23).
} 
De acordo com uma pesquisa quantitativa promovida pelo Instituto Pró-livro e coordenada pelo Observatório do Livro e da Leitura, denominada Retratos da leitura no Brasil, 2a edição, do ano de 2007, foi possível analisar alguns dados como: quem a pesquisa considera como leitor, o perfil deste, a preferência do leitor brasileiro, uso da biblioteca, a freqüência de leitura na semana em horas, as dificuldades quanto à leitura e outras variáveis.

Foram feitas 5.012 entrevistas. O estudo foi uma estimativa com um intervalo de confiança de 95\%, sobre 92\% da população brasileira, quantificada em 172,7 milhões de pessoas. Na pesquisa é considerado leitor aquele que leu um ou mais livros até três meses antes do estudo ser realizado. É considerado não-leitor aquele que não leu nenhum livro no mesmo período de tempo, ou que leu pelo menos um livro um ano antes. Segundo o próprio estudo, este não avalia aspectos qualitativos da leitura e nem o nível de compreensão de textos.

Para a variável: perfil do leitor brasileiro observa-se que 95,6 milhões, correspondem a 55\% da população estudada, e é o total de leitores identificados: destes 47,4 milhões (equivalente a 50\% dos 95,6 milhões) são estudantes e lêem livros que as escolas indicaram, principalmente didáticos; 6,9 milhões (7\% dos 95,6 milhões) estavam lendo a Bíblia. 41,1 milhões dos considerados leitores não são estudantes, destes 7,3 milhões estudaram até a $4^{\mathrm{a}}$ série do ensino fundamental, correspondendo a 9\% dos não estudantes; 10,6 milhões fizeram entre a $5^{\mathrm{a}}$ e $8^{\mathrm{a}}$ série do ensino fundamental e correspondem a $27 \%$ do grupo de leitores e, que não são estudantes; 14,9 milhões têm ensino médio e equivalem a 37\% do grupo; 8,5 milhões têm ensino superior e correspondem a 55\% também do grupo de não estudantes. Outras características apontadas do leitor no Brasil são que a maioria deles é formada por mulheres (55\%) e um terço deles menciona ler com freqüência 
(OBSERVATÓRIO DO LIVRO E DA LEITURA, 2007, p. 45-46).

Os não-leitores podem ser caracterizados, como: 77,1 milhões - que correspondem a 45\% da população estudada - não leram nenhum livro até três meses antes da realização da pesquisa; seis milhões afirmaram ter lido ao menos um livro, um ano antes da pesquisa; 4,5 milhões deles lêem a bíblia. Quanto à escolaridade dos não leitores, constataram-se os seguintes dados: $28 \%$ nãoalfabetizados; 35\% têm até a $4^{\mathrm{a}}$ série do ensino fundamental; $17 \%$ cursaram entre a $5^{\mathrm{a}}$ e $8^{\mathrm{a}}$ série do ensino fundamental; $19 \%$ têm ensino médio; $2 \%$ têm nível superior (OBSERVATÓRIO DO LIVRO E DA LEITURA, 2007, p. 102-103).

Com relação à variável dificuldade de leitura foi possível verificar os seguintes itens: 16\% responderam que lêem muito devagar; $7 \%$ não conseguem compreender a maior parte do que lê; $11 \%$ não têm paciência para ler; $7 \%$ não têm concentração; 8\% por ter limitações físicas, como a baixa visão; 15\% afirmaram que não são alfabetizados ou ainda não sabem ler; e $48 \%$ mencionaram que não tem dificuldade alguma (OBSERVATÓRIO DO LIVRO E DA LEITURA, 2007, p. 105).

Algumas preferências quanto ao suporte informacional, observadas são: a maior parte lê revistas correspondendo a $52 \%$; seguidos pelo livro - 50\%; jornais $48 \%$; livros indicados pela escola - 34\%; textos na Internet - $20 \%$; livros em braile - 0,2\%; entre outros (OBSERVATÓRIO DO LIVRO E DA LEITURA, 2007, p. 54).

Na variável tempo dedicado à leitura de livros, constata-se que: 2\% - 1,3 milhões - destinam mais de 10h por semana a essa atividade; 10\% - 8,7 milhões separam de $4 \mathrm{~h}$ a $10 \mathrm{~h}$ por semana; $51 \%$ - 44,7 milhões - de $1 \mathrm{~h}$ a $3 \mathrm{~h} ; 34 \%$ - 29,5 milhões, menos de $1 \mathrm{~h}$. O estudou mostrou que quanto maior o grau de escolaridade, maior é o tempo dedicado à leitura, por exemplo, a média de leitura 
para quem se afirmou ter até a $4^{\mathrm{a}}$ série e da $5^{\mathrm{a}}$ a $8^{\mathrm{a}}$ série, é de 1,6 hora; a média para indivíduos com ensino médio é de 2,2 horas; e, pessoas com nível superior é 2,4 horas de leitura (OBSERVATÓRIO DO LIVRO E DA LEITURA, 2007, p. 65).

Relativo à variável idade na qual os leitores costumavam ler mais, a pesquisa mostrou que: 29\% correspondem a crianças até dez anos; $4 \%$ equivalem a indivíduos com 11 anos; 6\% a 12 anos; 5\% a 13; com 14 anos - 5\%; 15 anos 7\%; 16 anos - 4\%; 17 anos - 4\%; 18 anos - 5\%; 19 anos - 2\%; 20 anos - 4\%; entre 21 e 25 anos - 6\%; de 26 a 30 anos - 4\%; entre 31 e 40 anos - 5\%; de 41 anos para cima - 4\%; 5\% não opinou (OBSERVATÓRIO DO LIVRO E DA LEITURA, 2007, p. 66) .

Com relação à questão da influência para a leitura na população estudada, constatou-se que: 49\% atribuem a mãe ou responsável mulher pela promoção do hábito de leitura; 33\% afirmam que foi a professora; 30\% que foi pai ou responsável homem; 14\% outro parente; 8\% amigo; 5\% padre, pastor ou líder religioso; 2\% colega ou superior no trabalho; $3 \%$ outros; $14 \%$ afirmaram que ninguém influenciou; 1\% não sabe ou não opinou. Segundo o estudo, os entrevistados podiam escolher duas alternativas (OBSERVATÓRIO DO LIVRO E DA LEITURA, 2007, p. 81).

O estudo verificou que três em cada quatro brasileiros não utilizam uma biblioteca, correspondendo a $73 \%$ da população estudada; os que a utilizam com freqüência equivalem a 10\%; e os que a usam de vez em quando equivalem a 17\%. Mostrou que a mesma é mais freqüentada, quando os leitores se encontram em período escolar, sendo que somente um em cada quatro alunos utiliza uma biblioteca pública municipal. Desses que freqüentam, avaliam-na da seguinte forma: $10 \%$ afirmam serem bem atendidos; $9 \%$ mencionam ser aquela bem 
cuidada; $7 \%$ que são atendidos por bibliotecários e 3\% por funcionários; 3\% não encontram todos os livros que procura; $1 \%$ considera que a biblioteca não é de fácil acesso. A pesquisa também mostrou que metade dos indivíduos que a freqüentam é composta de crianças e que $20 \%$ não a utilizam, pelos problemas que as unidades de informação apresentam. Também mostrou que $67 \%$ sabem se há biblioteca próxima a sua localidade; $13 \%$ não sabe se existe; e $20 \%$ respondem que não existe (OBSERVATÓRIO DO LIVRO E DA LEITURA, 2007, p. 94-95).

O estudo constatou que a forma pela qual os pesquisados - identificados como leitores: 95,6 milhões de pessoas - se valem para ter acesso ao livro são: emprestados por outras pessoas - 45\%; por meio de compras - 45\%; através de empréstimos em bibliotecas (incluindo as escolares) - 34\%; como presentes 24\%; distribuição de governos e/ou escolas - 20\%; baixados de forma gratuita pela Internet - 7\%; por meio de fotocópia - 7\%; não informou - 7\% (OBSERVATÓRIO DO LIVRO E DA LEITURA, 2007, p. 86).

Assim, o estudo possibilitou verificar quem é considerado leitor no Brasil; como é perfil deste; suas preferências; se tem o hábito de utilizar ou não a biblioteca, e se a utilizam e como a avaliam; quais as dificuldades relacionadas à leitura; o acesso ao livro; quem exerceu influência no hábito de leitura dos entrevistados.

Pode-se perceber que quanto maior o grau de instrução maior é o número de pessoas que se dedicam à leitura. Pode-se inferir que há relação entre baixa escolaridade e não ter o hábito de leitura, pois a pesquisa mostrou que somente 2\% dentre aqueles caracterizados como não-leitores pela pesquisa, têm nível superior.

Um dado interessante mostrado é o fato dos leitores freqüentarem mais a 
biblioteca, quando eram estudantes. Outro é que as crianças são as que mais lêem, corroborando o que já foi mencionado neste documento por Bamberger, citado por Válio (1990, p. 19) que o ideal é estimular o gosto pela leitura enquanto crianças.

Além disso, observa-se por meio do estudo que a família pode contribuir significativamente para criar a prática de ler, pois a mãe é apontada em destaque como a pessoa que mais exerce influência neste sentido para aquisição dessa prática.

É necessário que, professores e bibliotecários se unam para planejar programas de incentivo à leitura.

É válido que da mesma forma autoridades, criem políticas públicas que promovam a educação e o hábito de leitura, pois foi permitido verificar que é necessário desenvolver urgentemente a educação no Brasil e por ser o período escolar a época em que as pessoas lêem mais, segundo a pesquisa, é de extrema valia a implementação de bibliotecas nas escolas para a diminuição do analfabetismo e dos outros problemas relacionados à leitura.

\subsubsection{Políticas públicas de leitura no Brasil}

Em 2005, foi lançado no Brasil o movimento Vivaleitura, que tem por objetivo executar políticas de Estado sobre livro e a leitura. Foi determinada sua implementação pela XIII Cúpula de Chefes de Estado, dos países participantes da Organização dos Estados Ibero-americanos. O objetivo principal deste movimento é apoiar o "fortalecimento de planos nacionais do livro e da leitura nos países da região" (GONZÁLEZ, 2006, p. 8). No Brasil, essa iniciativa contou com a participação direta da Organização dos Estados Ibero-americanos, que elaborou a 
publicação "Cadernos da Ibero-América" e que "foram convidados a escrever sobre o tema personalidades do mundo da Cultura e Educação" (AMORIM, 2006, p. 12).

A relevância de uma publicação sobre este assunto se dá no sentido que chama atenção para o problema da falta de leitura. Pois, por meio da leitura que as informações são apreendidas, muitas vezes informações que podem mudar uma tomada de decisão. Da mesma forma, é imprescindível se ter um plano de ação para reduzir os problemas causados pelo falta de leitura.

O livro traz dados sobre os índices de leitura no país, por exemplo: no Brasil cada pessoa lê menos de um livro por ano, "contra 2,4 na Colômbia ou 7 da França [...] [devido] a dificuldade de acesso ao livro - seja pelo número insuficiente de bibliotecas públicas e de livrarias, seja pelo preço do livro, acima da capacidade de compra do brasileiro" (AMORIM, 2006, p. 14).

E, afirma Amorim que a causa dessa dificuldade se encontra na "ausência de habilidades técnicas necessárias para o exercício da leitura". Menciona também que somente "um em cada quatro brasileiros acima de 15 anos consegue ler e compreender textos um pouco mais complexos, já que os demais são analfabetos absolutos ou analfabetos funcionais" (AMORIM, 2006, p. 14).

De acordo com dados da Câmara Brasileira do Livro, o número de leitores em potencial no Brasil é de vinte e seis milhões de pessoas e que estes também se deparam com obstáculos para ter acesso ao livro e que a média de compras de livros por habitante é de 0,82 exemplar anualmente (AMORIM, 2006, p. 14).

Diante desse quadro, afirma Amorim que alguns esforços foram realizados para que essa situação melhore como "avanços significativos [...] nos últimos anos" em todas as esferas do governo "para fortalecer as bibliotecas, combater o analfabetismo, apoiar a produção e a livre circulação do livro e fomentar a leitura 
entre a população" (2006, p. 15). Esses esforços se concretizaram em ações como:

- 1999 - o Ministério da Cultura criou a Secretaria Nacional do Livro e Leitura;

- 2003 - o presidente da República sancionou a Lei do Livro, que institui a Política Nacional do Livro;

- 2004 - o Ministério da Fazenda desonerou o livro do pagamento de tributos;

- 2005 - o Ministério da Cultura reinstalou a Câmara Setorial do Livro e Leitura; e

- 2006 - o Ministério da Cultura e o Ministério da Educação criaram o Plano Nacional do Livro e Leitura.

Além disso, foi "consenso entre os atores sociais dessa política (educadores, escritores, editores, livreiros, bibliotecários, gestores, entre outros), sobre uma agenda nacional mínima pra o curto, o médio e longo prazo" (AMORIM, 2006, p. 16). Segue abaixo a agenda proposta pelos mesmos:

- definição de metas e responsabilidades dos vários atores no Estado, setor privado e terceiro setor para a Política Nacional do Livro até 2015 e 2022;

- implantação, fortalecimento e consolidação do Plano Nacional do Livro e Leitura (PNLL);

- estruturação de mecanismos de financiamento permanente do Estado e do setor privado para as políticas públicas do livro e da leitura;

- estruturação da área central de formulação, gestão e execução de ações na administração pública federal a fim de articular as iniciativas dos diferentes setores do Poder Executivo, em especial a Cultura e a Educação;

- estruturação pela sociedade, em colaboração com o Estado, de área de monitoração, estudos e pesquisas para apoiar e fortalecer a Política Nacional do Livro;

- intensificação das ações do Estado para erradicar o analfabetismo e reduzir o analfabetismo funcional; e

- intensificação das ações do Estado para financiamento, profissionalização e fortalecimento do sistema de bibliotecas públicas (municipais, estaduais, federais, comunitárias, escolares, universitárias).

Outro fator mencionado é a criação de um Observatório Nacional do Livro e da Leitura que teria a função de:

monitorar, avaliar, estudar, pesquisar e gerar números, estatísticas e, sobretudo, massa crítica em torno dessa política [...] cooperar com os responsáveis pela execução dessa políticas e com a própria sociedade, que é público-alvo e razão de ser delas (AMORIM, 2006, p. 17). 
O movimento Vivaleitura resultou na criação de um prêmio de âmbito nacional, o Prêmio Vivaleitura que tem por finalidade "estimular, fomentar e reconhecer as melhores experiências que promovam a leitura" ${ }^{2}$, e está distribuído em três categorias: bibliotecas públicas, privadas e comunitárias; escolas públicas e privadas; pessoas físicas, universidades e instituições.

Este movimento levou também à criação do Plano Nacional do Livro e Leitura "modelo de cooperação governo/sociedade civil" (MARQUES NETO, 2006, p. 27) e que foi lançado pelos Ministérios da Cultura e da Educação.

O Plano Nacional do Livro e Leitura está estruturado em quatro eixos: democratização do acesso, fomento à leitura e à formação de mediadores, valorização da leitura e da comunicação, e por último, desenvolvimento da economia do livro. Em consulta ao site do PNLL, foi possível verificar os eixos e linhas traçados pelo mesmo a seguir:

\section{Eixos e Linhas}

Eixo 1 - Democratização do acesso

1.1. Implantação de novas bibliotecas

1.2. Fortalecimento da rede atual de bibliotecas

1.3. Conquista de novos espaços de leitura

1.4. Distribuição de livros gratuitos

1.5. Melhoria do acesso ao livro e a outras formas de expressão da leitura

1.6. Incorporação e uso de tecnologias de informação e comunicação

Eixo 2 - Fomento à leitura e à formação de mediadores

2.1. Formação de mediadores de leitura

2.2. Projetos sociais de leitura

2.3. Estudos e fomento à pesquisa nas áreas do livro e da leitura

2.4. Sistemas de informação nas áreas de bibliotecas, da bibliografia e do mercado editorial

2.5. Prêmios e reconhecimento às ações de incentivo e fomento às práticas sociais de leitura

\section{Eixo 3 - Valorização da leitura e comunicação}

3.1. Ações para criar consciência sobre o valor social do livro e da leitura 3.2. Ações para converter o fomento às práticas sociais da leitura em política de Estado

\footnotetext{
2 Disponível em: <http://www.premiovivaleitura.org.br/default1.asp?page=concurso/concurso.asp $>$. Acesso em: 10 jun. 2009.
} 
3.3. Publicações impressas e outras mídias dedicadas à valorização do livro e da leitura

Eixo 4 - Desenvolvimento da Economia do Livro

4.1. Desenvolvimento da cadeia produtiva do livro

4.2. Fomento à distribuição, circulação e consumo de bens de leitura

4.3. Apoio à cadeia criativa do livro

4.4. Maior presença no exterior da produção nacional literária científica e cultural editada

Alguns projetos podem ser mencionados, como resultados dessas políticas, por exemplo, o Sistema Estadual de Bibliotecas Escolares - SIEBE, da Secretaria de Estado de Educação do Pará - SEDUC; sua atuação se dá nas escolas públicas para implementar e dinamizar ações que promovam a leitura; é gerenciado pelo Centro de Documentação e Informação da SEDUC; o público alvo é formado por pessoas no geral; e, são beneficiados em torno de 800.000 alunos e, no ano de 2008 atendeu a 370.000 .

Outro projeto criado é Sistema Informatizado de Bibliotecas Escolares SIBES, da Secretaria Municipal de Educação e Cultura - SMEC, do estado da Bahia; seu público alvo é formado por estudantes, professores, funcionários e usuários externos. Conforme o site do PNLL, este projeto proporcionou a informatização por completo da rede de bibliotecas escolares. Conforme o site do PNLL este projeto é a implementação

de uma nova sistemática de organização e informatização das Bibliotecas e Salas de Leituras das Escolas Municipais de Salvador - BA, com o objetivo de propiciar a democratização do acesso à informação de forma automatizada, visando à modernização, racionalização e otimização de seus serviços.

Os dois projetos foram formulados a partir do PNLL. Além desses, é possível citar também o vencedor do Prêmio Vivaleitura de 2008, o Projeto de Leitura Bibliotecas Escolares: Palavras Andantes (Londrina - PR), que não é em si um resultado dessa política, mas foi premiado por sua atuação junto às bibliotecas 
escolares formando mediadores nas escolas de Londrina. O projeto funciona da seguinte maneira:

\begin{abstract}
na rede municipal de ensino de Londrina (80 escolas), voltado para a formação de leitores nas escolas. Criado em 2002, o projeto tem quatro focos de atuação: formação continuada dos professores, realização semanal da Hora do Conto, reestruturação arquitetônica e pedagógica das bibliotecas escolares e ampliação dos acervos.

O diferencial da iniciativa é a formação dos mediadores, que fazem a ponte entre o livro e o professor. A formação é feita por meio de cursos mensais, desenvolvidos pelo próprio projeto. Até o momento, 135 mediadores já foram formados, beneficiando mais de 30 mil alunos da rede de ensino pública de Londrina. Segundo Rovilson José da Silva, responsável pelo projeto, o trabalho mostrou que não basta exigir que o professor seja um mediador da leitura. "Para criar uma rede de bibliotecas escolares comprometidas com a leitura de todos, foi preciso investir em várias frentes, oferecendo serviços, formando mediadores, ampliando o acervo e cuidando da parte física das bibliotecas e escolas".

Na reformulação das bibliotecas, a iniciativa leva em conta a ergonomia do ambiente de leitura, que deve ter mesas e cadeiras adequadas, e a parte estética também. "O incentivo à leitura também depende de um ambiente agradável e organizado", explica Rovilson. Mais de 70 bibliotecas escolares já foram reestruturadas pelo [projeto] Palavras Andantes.

"Acredito que a eleição do projeto como vencedor atesta a necessidade de uma política pública de leitura para a formação de leitores de verdade. Enquanto a biblioteca na escola não for eficiente, em seu acervo, instalações e serviços, a biblioteca pública também não o será", disse Rovilson na cerimônia de premiação.

Desde o princípio, a iniciativa vem aprimorando as estratégias para a formação de leitores nas 80 escolas da rede municipal. Em aproximadamente seis anos de atuação, ampliou os empréstimos de 72 mil para 650 mil exemplares.
\end{abstract}

Enfim, algumas políticas públicas criadas pelo governo brasileiro em conjunto com setor privado, terceiro setor, que podem citadas são a implantação da lei da Política Nacional do Livro, a isenção de impostos sobre o livro, o Plano Nacional do Livro e Leitura, o Prêmio Vivaleitura. E os resultados que foram constatados após a implementação desses planos de ação.

Esses planos tornam possíveis não apenas o desenvolvimento da leitura , mas também o progresso da sociedade como um todo, permitem igualmente uma inserção cada vez maior do indivíduo na Sociedade da Informação e do Conhecimento. 


\title{
4.3.6 Competência informacional
}

Nos dias atuais as crianças e jovens precisam estar preparadas para viver e tomar decisões numa sociedade que está em constante mudança e onde há um volume cada vez maior de informações. Ainda há correntes construtivistas que afirmam que o aluno aprende a partir do que estes vivenciam no seu cotidiano e as mesmas correntes dão privilégio para o aprendizado com base no "questionamento e utilizam estratégias didáticas adequadas à preparação da pessoa para viver na chamada sociedade de informação" (CAMPELLO, 2005, p. 9). Assim, essa sociedade por ser caracterizada por um grande número de informações, exige que o indivíduo saiba utilizar essas informações de forma eficaz na solução de problemas e situações do dia-a-dia.

Ao tratar de competência informacional afirma Belluzzo que:

\begin{abstract}
Ressalta-se que o conceito de competência traz à tona várias concepções, porém, vamos entendê-la como sendo um composto de duas dimensões distintas: a primeira, um domínio de saberes e habilidades de diversas naturezas que permitem a intervenção prática na realidade e, a segunda, uma visão crítica do alcance das ações e o compromisso com as necessidades mais concretas que emergem e caracterizam o atual contexto social (2008, p. 13).
\end{abstract}

Segundo Campello (2003, p. 28), o termo surgiu na década de 1970 nos Estados Unidos e em termos conceituais pode-se dizer que a competência informacional são as habilidades desenvolvidas para se fazer uso adequado da informação, isto é, saber localizá-la e compreendê-la, por exemplo. No início de seu uso, o termo significava o conhecimento para "lidar com a tecnologia da informação, isto é, computadores e redes eletrônicas" (CAMPELLO, 2005, p. 9).

Ainda, conforme Campello (2003, p. 30), a partir de seu surgimento a competência informacional teve sua aplicação em diferentes contextos, como para Behren, ele estava relacionado ao uso de "produtos informacionais disponíveis no 
mercado [...] e direcionadas na solução de problemas no seu trabalho"; para Hamelink e Owens (apud BEHRENS, 1997, p. 310 apud CAMPELLO, 2003, p. 30) essa palavra estava ligada "à questão da cidadania [...] cidadãos competentes no uso da informação teriam melhores condições de tomar decisões relativas à sua responsabilidade social".

A partir de 1980, começou-se a assimilar o conceito de competência informacional na literatura biblioteconômica, enfatizando no bibliotecário a função pedagógica, isto é, que o profissional deveria fazer parcerias com professores e gestores das escolas "no planejamento do programa da biblioteca, de acordo com as necessidades específicas da escola" (CAMPELLO, 2003, p. 30).

Assim, o papel do bibliotecário dentro da biblioteca escolar não é somente de dar o acesso e recuperar a informação, mas também de auxiliar o aluno para que este possa desenvolver a competência informacional, que atualmente é utilizada para indicar "de forma ampla, o conjunto de habilidades necessárias para localizar, interpretar, analisar, sintetizar, avaliar e comunicar informação, esteja ela em fontes impressas ou eletrônicas" (CAMPELO, 2005, p. 9-10).

Conforme Stripling (1996, apud CAMPELLO, 2003, p. 31) de acordo com sua função pedagógica, os papéis do bibliotecário neste contexto podem ser definidos como:

"Caregiver": a noção de aprender traz em si uma conotação afetiva, onde o bibliotecário tem de dar suporte à aprendizagem individualizada e auxílio a cada aluno conforme seus interesses e necessidades.

Orientador: nesta função o profissional deve estimular a aprendizagem, fazendo com que o aluno busque "fontes de informação, estratégias" e soluções para seus questionamentos e necessidades. 
Elo: nesta função o bibliotecário servirá de ligação entre o aluno e os recursos informacionais disponíveis.

Catalisador: o bibliotecário é como um propulsor para mudanças no estilo de aprendizagem "tendo em vista sua posição na escola", agindo como um colaborador "no planejamento curricular e facilitador da aprendizagem" (STRIPLING, 1996, p. 641-649 apud CAMPELLO, 2003, p. 31).

A competência informacional é um assunto ainda pouco discutido no Brasil, começou com Caregnato em 2000. Como menciona Campello (2003, p. 29) alguns autores brasileiros que trataram do tema ainda que em "perspectivas distintas, têm em comum o fato de perceberem a necessidade [...] de ampliar a função pedagógica da biblioteca [...] construir um novo paradigma educacional para a biblioteca e de se repensar o papel do bibliotecário".

De acordo com Campello outro ponto que está ligada à competência informacional é o letramento. Ao menos, segundo a autora, no Brasil entende-se a competência informacional como parte do letramento, pois o mesmo compreende o ato de ler e escrever e da mesma forma envolve suas práticas de leitura e escrita (CAMPELLO, 2003, 2005, p. 10).

Campello (2005, p.10) ainda menciona que é possível perceber que a competência informacional está relacionada: ao "ensino no qual o professor é [...] o orientador que capta os interesses dos alunos e estimula seus questionamentos e os guia na busca de soluções"; a "projetos interdisciplinares que" irão permitir aos estudantes considerarem atentamente um tema sob variadas visões; também se relaciona com a disponibilidade de inúmeros recursos de informação em diversos suportes como materiais impressos, audiovisuais, eletrônicos, entre outros, e que esses recursos possam ser utilizados "em espaços onde o aluno tenha a 
oportunidade de usá-los para localizar e selecionar informação" (CAMPELLO, 2005, p. 10).

Outro fator importante é como a biblioteca escolar pode ser instrumento no auxílio do desenvolvimento das habilidades informacionais. De acordo com Campello, a biblioteca é o ambiente propício para que o estudante amplie sua capacidade de assimilar e utilizar informações, pois ela pode "aproximar o aluno de uma realidade que ele vai vivenciar no dia-a-dia como profissional e cidadão" (CAMPELLO, 2005, p. 11).

E a biblioteca pode tornar-se um ambiente favorável ao desenvolvimento dessas habilidades, por meio de um programa elaborado em conjunto pela direção da escola, professores e bibliotecários, com a finalidade de que o conteúdo transmitido promova "oportunidades de aprendizagem que dêem condições de aprender a aprender, permitindo-Ihe educar-se durante a vida" (CAMPELLO, 2005, p. 11).

Ainda a parceria entre bibliotecários e professores, envolve o planejamento de "situações de aprendizagem que desafiem e motivem os alunos, acompanhando seus progressos, orientando-os e guiando-os no desenvolvimento de competências informacionais" (CAMPELLO, 2005, p. 11).

Belluzzo sugere a interação entre bibliotecários e professores, ocorra da seguinte forma:

- Preparação de diretrizes básicas para iniciativas conjuntas sob o enfoque das necessidades da sociedade da informação e dos princípios da Competência em Informação, uma atividade intra-curricular.

- Definir as condições para que tais iniciativas possam ser apoiadas por políticas e pelas comunidades assistidas.

- Implementar e criar mecanismos de manutenção e avaliação das práticas pedagógicas e informacionais $(2008$, p.13). 
Em suma, a competência informacional é o conjunto de habilidades que permite ao indivíduo, mais especificamente o aluno, identificar, selecionar, interpretar, aplicar a informação para adquirir conhecimento e gerá-lo. É possível constatar mais uma vez como é importante a atuação do bibliotecário neste aspecto possibilitando ao aluno o acesso e aptidão no uso dos recursos informacionais. E igualmente é imprescindível a integração entre as áreas de Educação e Biblioteconomia, com a finalidade de reforçar e desenvolver tais aptidões.

\subsubsection{Biblioteca escolar no Brasil}

A biblioteca escolar no Brasil pode ser caracterizada pela importância que possui; pela falta de recursos informacionais, financeiros, humanos; pela infraestrutura; o papel do bibliotecário neste tipo de unidade de informação e o envolvimento de outros atores envolvidos neste cenário como autoridades competentes, educadores, gestores das instituições educacionais; por fatores externos e internos relativos à sua não utilização.

Santos afirmou, que a biblioteca escolar no Brasil era algo relativamente novo. Nos anos de 1970, as escolas de todos os níveis eram desprovidas de bibliotecas. A maioria das que existiam funcionavam "de forma completamente precária [...] instaladas em salas de recreação, em corredores do pátio escolar, e até em vestiários" (1973, p. 117). Por meio da literatura percebe-se que esta situação pouco mudou.

Observa-se no Brasil uma insensibilidade relativa à biblioteca escolar, principalmente na escola pública do ensino fundamental, como descreve Silva (1995, p. 11). Este autor menciona que pouco se sabe de iniciativas do governo 
que tenham por objetivo o melhoramento das "condições de funcionamento das bibliotecas" nas escolas brasileiras. Provavelmente não seja apropriado mencionar que se procure um melhoramento "para não dar a falsa impressão de que até existem certas condições de funcionamento, que apenas precisam ser aprimoradas", pois, às vezes, não se pode afirmar que as bibliotecas das escolas públicas constituem-se de fato como bibliotecas (1995, p. 12-13).

Percebe-se, igualmente, uma apatia por parte dos bibliotecários, que segundo Silva estão mais preocupados com a comunicação científica e sistemas de informação automatizados que com temas como a biblioteca escolar no Brasil (1995, p. 20).

Quanto à indiferença, também demonstrada por professores, Silva afirma que estes se recusam a utilizá-la, renegam seu papel no processo de ensinoaprendizagem. É válido levar em conta que a razão para tal indiferença dos professores se explica pela sua formação, que em seus cursos e livros didáticos pouco mencionam sobre a importância da unidade de informação escolar como instrumento complementar a esse processo (1995).

Geralmente, caracteriza-se como uma unidade de informação de escola pública: "espaços" que parecem mais "depósitos de livros" que em sua maioria não são usados por encontrarem-se danificados, e

\footnotetext{
um armário trancado, situado numa sala de aula, ao qual os alunos só têm acesso se algum professor se dispõe a abri-lo [...] quando a chave é localizada. Outras vezes, a biblioteca, razoavelmente instalada, funciona em horários breves e irregulares, sendo uma verdadeira loteria adivinhar quando ela estará aberta. Há situações em que o espaço da biblioteca escolar é utilizado não como lugar de estudo, de pesquisa ou leitura, mas de punição [...] é o espaço onde os alunos vão copiar verbetes, trechos ou parágrafos dos mesmos livros e enciclopédias 'receitados' pelos professores, 'desde os tempos imemoriais' (SILVA, 1995, p. 13).
} 
É válido mencionar os recursos humanos, que na maioria das vezes, não é qualificado, não tem formação acadêmica nem especialização para trabalhar na biblioteca escolar, principalmente quando diz respeito ao planejamento, à organização, à administração da biblioteca, bem como ao acesso e uso dos documentos, à promoção da leitura e à elaboração de pesquisas entre os estudantes. Atinente à equipe técnica da biblioteca em escolas públicas pode-se constatar que são professores próximos de sua aposentadoria que foram recolocados por motivo de doença e outros, e que não foram readaptados.

Em um trabalho apresentado por Furtado (2004, p. 5) no III Seminário Biblioteca Escolar Espaço de Ação Pedagógica, a autora aponta algumas diretrizes para que se tenha uma otimização dos recursos humanos na biblioteca da escola, as quais são colocar na equipe de trabalho da biblioteca profissionais da área de Biblioteconomia, Educação, Artes, ou estudantes de graduação das respectivas áreas, coordenados por um bibliotecário, e atuando como auxiliares com devido treinamento em Biblioteconomia.

Macedo afirma que é preciso uma valorização do bibliotecário perante a comunidade escolar, para isso é imprescindível o posicionamento das autoridades biblioteconômicas (2005, p. 45).

Ferreira a respeito deste tema discorre que é interessante haver um sistema de bibliotecas escolares que seja eficaz para solucionar de certa forma a questão da inexistência ou pouca existência da biblioteca na escola, esta afirma que não é preciso um profissional formado em Biblioteconomia em cada escola (1977, p. 711).

Corrobora neste sentido Furtado, afirmando também que se tenha um sistema de bibliotecas, onde a biblioteca central esteja sob a gestão de um 
bibliotecário, sendo que este coordena as atividades e serviços da biblioteca onde atua e as atividades das demais unidades de informação (2004, p. 5). Fernando Modesto (2005, p. 228) também afirma que é interessante salientar que onde não for possível a presença deste profissional, poderia se contar com uma rede de bibliotecas com um número determinado de bibliotecários responsáveis por elas.

Um projeto recentemente elaborado pelo Conselho Federal de Biblioteconomia, denominado "Projeto Mobilizador Biblioteca Escolar: Construção de uma Rede de Informações para o Ensino Público" ${ }^{3}$ foi apresentado em maio de 2009, no Senado Federal à Comissão de Educação, Cultura e Esporte (CE), pela atual presidente do conselho, Nêmora Rodrigues, o objetivo é o fortalecimento das bibliotecas e sua integração nos programas políticos-pedagógicos. E tem como objetivo geral "contribuir efetivamente para a qualidade do ensino, no território nacional, que tire o Brasil de uma situação de difícil no que tange à circulação da informação e do conhecimento na escola pública, em geral" (CONSELHO FEDERAL DE BIBLIOTECONOMIA, 2008?, p. 25).

Uma razão para se ter uma rede, pode ser explicada pelo fato do número de escolas brasileiras, ser maior que o número de profissionais formados na área de Biblioteconomia. Por exemplo, segundo dados em 2000, o número de escolas excedia a 220.000, e de profissionais registrados não chegava a 25.000 no território brasileiro. Ficando inviável, portanto, de suprir todas as escolas com esses profissionais (FURTADO, 2004, p.4-5).

Furtado discorre que é necessária a existência de legislação adequada

\footnotetext{
${ }^{3}$ Disponível em: http://www.cfb.org.br/UserFiles/File/PROMOBILFINAL.pdf. Acesso em 31/05/2009.
} 
sobre essa unidade informativa, e que esta legislação precisa estar fundamentada em experiências com a biblioteca da escola (2004, p. 3).

Macedo e outros (2005) têm o mesmo pensamento relativo ao tema. O Manifesto UNESCO/Ifla para as bibliotecas escolares, aconselha que as mesmas precisam ser regulamentadas pelo governo em todas as esferas e deve ter o suporte financeiro deste.

Martucci cita que a regulamentação da biblioteca escolar deve ser efetuada em âmbito federal, por abranger todo o território brasileiro. E exemplifica ação neste sentido, como a iniciativa da deputada Esther Grossi ao propor um projeto de lei $n^{\circ} 3.549 / 2000$, o qual versava sobre a implantação de bibliotecas escolares em todo o Brasil, gerenciadas por um bacharel em Biblioteconomia, com um acervo mínimo de quatro livros por estudante matriculado, entre outros, porém não obteve êxito para que a legislação entrasse em vigor, devido à mesa diretora da Câmara dos Deputados, observar que no Regimento Interno da casa, do ano de 2003, constar no artigo 105 "que proposições que ainda se encontrem em tramitação, finda a legislatura, serão arquivadas" (2005, p. 219).

A mesma cita outras leis de caráter estadual, tal qual a lei $n^{0}$ 5.031/1986 elaborada pelo governador de São Paulo que trata da inclusão obrigatória de um espaço apropriado para as bibliotecas nas escolas. Outro exemplo também pode ser mencionado como o projeto de lei $n^{0}$ 5/2002 elaborada por uma aluna de ensino fundamental do Parlamento Jovem da Assembléia Legislativa de São Paulo, que propunha, que o espaço físico destinado a unidade de informação fosse de 1.000 metros, e esse espaço deveria ser aproveitado da seguinte forma com: 
sala de multimídia, com [12] computadores e ligados a Internet; oficina de leitura e escrita; oficina de artes; salão recreativo (com palco, lanchonete e espaço livre); possuir dois bibliotecários e dois especialistas em informática, além de professores e voluntários (MARTUCCI, 2005, p. 222).

Relativo à legislação, Modesto também ratifica a importância do projeto de lei compilado pela deputada Esther Grossi, e cita outros como o decreto 81.967/78, que modifica a redação de outro decreto, o 77.565/76, no qual aborda a questão de "aplicações dos recursos do Fundo de Participação dos Estados", mencionando que nos decretos $20 \%$ dos recursos devem ser destinados à educação, cultura e cita de certa forma, a biblioteca na escola. Afirma o autor, que é necessária a pressão da sociedade e aponta como alternativa, leis que estimulem as pessoas e empresas a realizarem doações para a criação e conservação das bibliotecas escolares (2005, p. 227 e 229).

Sobre o financiamento à biblioteca escolar, é relevante afirmar que em consulta ao orçamento federal no site do Senado Federal realizado por Fernando Modesto, o mesmo observou que são pouquíssimas as verbas destinadas àquela (2005, p. 227).

Ainda sobre a questão financeira da biblioteca escolar os autores afirmam que é preciso discutir a respeito do bibliotecário que também é figura importante neste cenário educacional, questões salariais, provimento de cargos por meio de concursos no caso de bibliotecas de escolas públicas, e, mencionam Garcez e Blattmann que as bibliotecas deveriam conter equipes interdisciplinares para terem atuação otimizada no processo de ensino-aprendizagem, e igualmente para que o profissional de Biblioteconomia não fique sobrecarregado com atividades e serviços (2005, p. 233). 


\subsubsection{Fatores externos e internos que levam a não utilização da biblioteca}

\subsection{Fatores externos}

Muitas são as razões que levam a não utilização da biblioteca na escola pública. Um estudo realizado por Medina (1975, apud SILVA, 1995, p. 44) comenta que existe um número reduzido de bibliotecas escolares. Na época que foi realizada a pesquisa, constatou-se que menos de $30 \%$ de municípios do Brasil tinham bibliotecas. Alguns estudos, mais atuais que estes, afirmam que desde aquele tempo não houve mudança significativa quanto a essa situação (SILVA, 1978; MILANESI, 1986; GEBPE-DF, 1986; apud SILVA, 1995, p. 44).

A relevância de uma biblioteca na escola deve-se ao fato de que ela ajudaria a solucionar, ou ao menos amenizar, o problema do analfabetismo e da baixa escolaridade (SILVA, 1995, p. 45), e o seu papel de complemento ao processo de ensino-aprendizagem.

Silva afirma que se o problema é promover o uso da biblioteca escolar, existe outro ainda pior. No Brasil precisa-se ainda inventariar a sua situação, visto que de organização para organização muda o "conceito" do que seria uma biblioteca na escola, enfim fazer um diagnóstico da situação.

Quanto aos fatores externos de funcionamento da biblioteca, Silva (1995, p. 48-57) enumera alguns, como:

- "falta de tradição bibliotecária no Brasil [...] sendo reforçada, historicamente pela política cultural", que o autor afirma ser mais apropriado dizer que esta não existe, pois a elite cria meios para haver um desestímulo do que é produzido culturalmente pela massa e obstáculos para a existência de difusão entre a população da leitura, 
do livro e da biblioteca;

- inabilidade para utilizar os recursos informacionais da biblioteca, onde o autor explica que professores e bibliotecários devem buscar soluções, ou, ao menos, meios de amenizar esta situação.

- utilização massiva de aulas expositivas, contribuindo para o afastamento do estudante do espaço da biblioteca;

- atitude de cobrança da leitura por parte do professor, que impõe textos a serem lidos e que exigem notas para a leitura dos mesmos.

- outro fator indicando a ausência do aluno na biblioteca é uso freqüente de apostilas e cópias, sendo que na maior parte das vezes não tem, ao menos, a referência do texto copiado, tendo em vista a escassez de recursos disponibilizados à unidade de informação e ao sistema escolar público.

Para solucionar esses problemas é necessária uma discussão que leve a um plano de ação, com estabelecimento de diretrizes que os resolvam.

\subsection{Fatores internos relativos a não utilização da biblioteca escolar}

Quantos aos motivos internos que explicam a não utilização da biblioteca escolar, Silva os denomina como "fatores intrabibliotecários", por serem estes oriundos da estrutura, funcionamento da biblioteca e da atuação "profissional do bibliotecário escolar" (1995, p. 48).

O autor enumera diversas causas para que essa situação ocorra: coleção da unidade de informação ser pobre e não atualizada, devido a carência de recursos, "que não atinge apenas a biblioteca mas a escola pública, como um todo"; a forma como estão organizados os documentos nas estantes e seu sistema de 
classificação e recuperação também interferem nessa situação (1995, p. 57-58); as normas muitas rígidas de funcionamento da biblioteca; horários sem flexibilidade; inexistência de um elo de ligação com as atividades desenvolvidas na escola, pois há determinados momentos que a biblioteca funciona fora do estabelecido, de acordo com as necessidades do profissional que ali trabalha, contribuindo para o afastamento do leitor, da biblioteca escolar.

Além dos fatores citados anteriormente, incluem-se outros, conforme Silva: o serviço de empréstimo carregar uma noção de punição, quando um usuário devolve o material em tempo maior que o previsto, e paga uma multa $(1995$, p. 5859). Este autor afirma que certas unidades de informação não disponibilizam este serviço para os usuários, alegando que o aluno ainda não tem habilidade para desenvolver a responsabilidade para utilizar tal serviço. Além disso, há certas bibliotecas que seguem a mesma lógica de pensamento citado anteriormente, quanto ao acesso às estantes, com a finalidade de conservar o acervo. Silva cita que esses procedimentos levam o usuário a não quererem freqüentar a biblioteca escolar (1995, p.59).

A conduta "passiva e excessivamente técnica" dos recursos humanos ou da pessoa responsável pela biblioteca, inibe o uso completo desta. Por que geralmente os que trabalham na mesma, principalmente se a biblioteca for de escola pública, são professores recolocados sem formação específica (SILVA, 1995, p. 60).

Até mesmo os bibliotecários têm certas atitudes que Silva chama de "antiusuário", por exemplo: preocupar-se em demasia com o silêncio e arrumação da biblioteca e preocupar-se com detalhes técnicos como o número de chamada que o documento terá, ao invés de criar mecanismos que atraiam o professor e o 
aluno para a biblioteca escolar (1995, p. 61, 63).

É importante lembrar que não se deve atribuir somente ao profissional o encargo de preocupar-se em excesso com a parte técnica. Por exemplo, os cursos também, que levam mais em conta os detalhes técnicos do que o atendimento ao usuário, tornando-se necessário questionar os padrões de ensino e levar o profissional a uma postura mais dinâmica e proativa em relação à biblioteca escolar (SILVA, 1995, p. 63).

Dessa forma, Silva discorre sobre temas relativos à freqüência ou não da biblioteca escolar, mostrando que é preciso estar atento a essa questão, tendo em vista os papéis que a biblioteca escolar desempenha quando existe e quando realmente é reconhecido o seu valor. Ainda mais num país como o Brasil, carente de conhecimento que leve ao desenvolvimento e melhoria das qualidades de vida, e onde a maioria dos estudantes pode obter contato com informação e leitura por meio da biblioteca na escola.

Além disso, é importante levar em conta outros assuntos discorridos pelos estudiosos como o financiamento da biblioteca escolar, a relevância de se ter uma legislação específica sobre a mesma, qual o cenário apresentado relativo ao tema no Brasil, a importância do profissional bibliotecário neste contexto. Como a biblioteca de escola no contexto brasileiro é importante, pois uma das suas funções é desenvolver o senso de cidadania na criança, no jovem e até mesmo no adulto em processo de alfabetização, ser também uma alternativa de lazer, entre outros. 


\subsubsection{O papel do bibliotecário na biblioteca escolar}

Para cada tipo de organização e profissão é necessário que se tenha conhecimento para poder operar tarefas que são peculiares a cada instituição e tipo de trabalho, quer seja técnico, quer seja específico. Para isso, o bibliotecário é o profissional adequado para se trabalhar em unidades de informação ou bibliotecas, sejam elas de qualquer natureza, até mesmo porque investiu numa especialização para ter uma atuação direcionada a determinadas atividades.

O bibliotecário deve se perguntar qual o seu papel, como o usuário da biblioteca o percebe, entre outras questões (CALDIN, 2005, p. 165).

O bibliotecário é elemento fundamental para qualquer tipo de biblioteca e muitas vezes as autoridades governamentais insistem em não reconhecer a importância deste profissional, por exemplo, burlando leis como a legislação número 4.084/62 (sobre "O Exercício da Profissão de Bibliotecário e das suas Atribuições"), como afirma Ferreira. Algo que comprova isto é o fato de na época, anos de 1970, em São Carlos, São Paulo, com uma população de 85.495 habitantes e uma biblioteca pública com 27.000 livros em seu acervo "jogados em salas inadequadas de Ginásios e Grupos Escolares, [não existia sequer um bibliotecário encarregado daquele] patrimônio cultural" (1977, p. 709).

Mais recentemente, Furtado apresentou um trabalho no III Seminário Biblioteca Escolar Espaço de Ação Pedagógica no ano de 2004, mostrando que no Brasil existiam 220.000 escolas e 25.000 profissionais formados em Biblioteconomia, isto é, a situação atualmente não é tão diferente de 30 anos atrás.

É necessário que a biblioteca esteja sob a administração de um profissional competente, que é o bibliotecário.

Silva discorre a respeito do papel do bibliotecário e afirma que a este não 
deve recair a inteira responsabilidade pela biblioteca escolar, que "toda a comunidade escolar" precisa atuar dentro da mesma. Ele menciona que deve ser assim, para que não aconteça de o bibliotecário pensar que é proprietário da unidade de informação, como se ninguém além dele "pudesse interferir na biblioteca (ou 'estática')” (1995, p. 75).

É preciso que o profissional da informação desenvolva atividades que sejam compatíveis com os interesses da clientela a ser atendida, e que esta deve participar do processo de seleção e aquisição.

É importante que não se executem os serviços de processamento técnico da coleção de forma robótica, mas leve-se em conta "as características e limitações dos usuários da biblioteca". Silva escreve que se deve evitar o "tecnicismo alienante" e procurar um equilíbrio entre as atividades técnicas e outras que dizem respeito à biblioteca (1995, p. 75).

O bibliotecário deve lutar por recursos para a unidade de informação, mas Silva alude para o fato de que responsabilidade não ficaria limitada a ele "mas também a direção da escola, os professores", os estudantes e os pais (1995, p. 76).

Deve criar maneiras para que a coleção da biblioteca seja diversificada e quando esta não for satisfatória, o profissional precisará se empenhar para ter criatividade de forma que ele tenha um atendimento regular; o acervo deve ser composto de materiais que levem à "formação social, intelectual, cultural e crítica (literatura, filosofia, psicologia e ciências afins)". Caldin afirma, ainda, que cabe ao profissional da informação: "agir com dinamismo, driblando as dificuldades financeiras e entraves burocráticos das bibliotecas escolares; principalmente, as da rede pública"; ter capacidade de ser diplomático e persuasivo "para montar um 
acervo rico e diversificado" (2005, p. 165).

Trabalhar em parceria com os professores no processo de seleção e aquisição de obras. Conhecendo os leitores e suas preferências (pode-se inferir que isso é possível por meio de estudos de usuários, certamente), poderá opinar sobre a escolha dos materiais. Caldin adverte que essa tarefa não cabe exclusivamente a professores. Da mesma forma, é necessário que esteja apto a reconhecer uma literatura infantil que não seja tendenciosa nem preconceituosa (2005, p. 166).

Compete ao bibliotecário participar do "planejamento didático do professor", pois, assim este terá oportunidade para "orientar com maior objetividade e eficácia a inserção da biblioteca" no processo de ensino-aprendizagem (SILVA, 1995).

Da mesma forma, o bibliotecário precisa interagir com o professor, entendo a área da educação, e fazendo realmente com que a biblioteca seja uma ferramenta de complemento ao processo de ensino-aprendizagem.

É também de sua competência orientar os usuários quanto ao funcionamento da biblioteca, a disposição da coleção nas estantes, o horário de funcionamento e principalmente estimular o interesse pela leitura.

É necessário, ainda, que este profissional entenda cada aluno com suas idiossincrasias, se empenhe para encontrar a informação adequada para o estudante; e juntamente com o professor, mostre ao aluno como consultar os materiais, ensinando-os sobre as características de cada tipo de documento e suas finalidades, esteja ele em meio impresso, audiovisual ou eletrônico/virtual; precisam formar parcerias para promover atividades que promovam a independência do estudante na identificação, localização, seleção e uso da informação.

Caldin menciona que o papel da biblioteca escolar estende-se ao 
profissional, o qual seja: "estimular, coordenar, organizar o processo de leitura para que, por meio dela, a criança/adolescente/jovem aumente seus conhecimentos, sua capacidade crítica e reflexiva que lhe permitam atuar melhor na sociedade" (2005, p. 163). E para isso, afirma, ainda, que este profissional precisa comprometer-se a ser culto, "buscar, ser um autodidata em cultura geral" ler ao menos, "todos [os livros que forem possíveis]" (2005, p. 165).

Enfim, pode-se observar como são diversas, as atribuições do bibliotecário e como são importantes. Dentre elas a promoção da leitura e do conhecimento; a organização e administração dos recursos informacionais e financeiros; orientação dos usuários. Percebe-se, da mesma forma, como é extraordinário e importante que este trabalhando em conjunto com o professor, esteja atento para a dinamização da biblioteca. 


\section{Considerações finais}

Este estudo tratou da Sociedade da Informação e do Conhecimento, o papel da biblioteca nesta sociedade, e principalmente da biblioteca escolar quanto a alguns aspectos gerais e, no Brasil, um pouco da sua realidade. Permitiu à autora aprofundar o conhecimento sobre biblioteca escolar concernente a vários aspectos como: o seu conceito, seu papel, assuntos relacionados à mesma como pesquisa escolar, leitura, competência informacional, a organização de seu espaço, entre outros.

Foi possível identificar o significado de biblioteca escolar e o seu papel, que é ser um complemento ao conteúdo ensinado em sala de aula e ao ensinoaprendizagem, além de estimular a leitura.

Observou-se que a biblioteca precisa ter uma estrutura bem definida, com espaço aconchegante e ter parâmetros para a organização deste espaço, bem como parâmetros para seu funcionamento.

O acervo da biblioteca escolar é um requisito significativo. Se relacionando com ele os materiais que o compõem, a política para sua formação, seu tratamento informacional através de padrões e a questão da educação infantil.

Sobre a pesquisa escolar, este estudo possibilitou compreender o contexto, no qual a mesma foi implantada no Brasil, quais os indivíduos envolvidos neste processo de pesquisa, alguns casos concretos de pesquisa escolar, como o de Bicheri e o estudo do Grupo de Estudos em Biblioteca Escolar da UFMG e a relação pesquisa escolar e Internet.

Pertinente à leitura, é válido lembrar que os estudiosos mostram que se deve criar o gosto pela leitura desde cedo, como mostrou Bamberger e verificou-se que a família tem influência para cultivar o hábito de leitura. Além disso, discorreu- 
se sobre algumas políticas públicas de leitura no Brasil.

Discorreu-se sobre competência informacional, que é denominada também letramento informacional.

Pode-se verificar que há uma relação entre leitura, competência informacional e pesquisa escolar, uma vez que a leitura é a apreensão da informação e, a competência é a aptidão para apreendê-la e estudá-la, por fim a pesquisa que é a prática que une o estudo e habilidade de estudar, analisar e internalizar a informação, produzindo o conhecimento.

Os aspectos que foram abordados neste documento, sobre a biblioteca escolar brasileira, seguem: da indiferença demonstrada; os fatores externos e internos a ela, que fazem com que a mesma não seja utilizada; da importância de se ter uma legislação específica para este tipo de biblioteca em todas as esferas do governo, e mostra algumas iniciativas, na tentativa de fomentar o uso e valorização da mesma, como o projeto de lei $n^{0} 5.349 / 2000$, elaborado pela deputada Esther Grossi, que foi arquivado.

E do bibliotecário escolar tratou-se da importância da presença deste profissional e de seu papel dentro da biblioteca escolar.

Em suma, os aspectos tratados nesta monografia permitiram à autora entender um pouco mais sobre biblioteca escolar e de forma geral como se encontra a situação no contexto brasileiro. 


\section{Levantamento bibliográfico seletivo comentado sobre biblioteca escolar}

Este levantamento procura apresentar os documentos relativos à biblioteca escolar no Brasil.

Ele está organizado por tipo de documento (artigos, livros, sites e base de dados, teses e dissertações), em ordem alfabética de autor. Inclui, além da referência, resumos de artigos, teses e dissertações, sumário, sinopse ou descrição dos livros. Em algumas citações foram colocadas palavras-chave.

\subsection{Artigos:}

BARROSO, Maria Alice. Um modelo flexível para a biblioteca escolar. Revista Brasileira de Biblioteconomia e Documentação, v.17, n.1/2, p. 12-17 jan./jun. 1984.

Resumo: Relata fatos e ações ocorridos a partir da Reunião Latino Americana sobre Bibliotecas Escolares, ocorrida em Lima, em 1983, em que estiveram presentes representantes de 17 países, ocasião em que foi apresentado o Modelo Flexível para um Sistema de Bibliotecas Escolares. Apresenta sugestões e recomendações para a implantação de bibliotecas escolares, emanadas de diversos documentos, ressaltando a necessidade de se entendê-la como um laboratório de aprendizagem.

BEHR, Ariel; MORO, Eliane Lourdes da Silva; ESTABEL, Lizandra Brasil. Gestão da biblioteca escolar: metodologias, enfoques e aplicação de ferramentas de gestão e serviços de biblioteca. Ci. Inf., Brasília, v. 37, n. 2, p. 32-42, maio/ago. 2008. Disponível em: <

http://revista.ibict.br/ciinf/index.php/ciinf/article/view/1043/756>. Acesso em: 18 maio 2009.

Resumo: Este artigo apresenta a gestão da biblioteca escolar com enfoque na aplicação de ferramentas de gestão para avaliação da qualidade dos serviços oferecidos. Aborda as questões de qualidade e de administração como gestão garantindo aos serviços as características das expectativas e necessidades dos usuários da biblioteca escolar. O bibliotecário, como gestor dos serviços prestados na tomada de decisão, tem competência para utilizar as ferramentas que auxiliam a avaliar seus serviços, como brainstorming, diagrama de causa e efeito, diagrama de Pareto, histograma, matriz de priorização GUT, ciclo PDCA, fluxograma e $5 \mathrm{~W} 2 \mathrm{H}$. Apresenta ainda algumas situações de problemas e dificuldades no âmbito da biblioteca escolar exemplificadas na utilização das ferramentas e a aplicação da junção de três ferramentas (fluxograma, PDCA e 5W2H) para avaliação dos serviços. 
BUENO, Silvana Beatriz. Acesso e uso da informação em ambiente educacional: fontes de informação. Revista ACB: Biblioteconomia em Santa Catarina, Florianópolis, v. 11, n. 1, p. 53-62, jan./jul. 2006. Disponível em: <http://www.acbsc.org.br/revista/index.php/racb/article/viewFile/464/584>. Acesso em: 18 maio 2009.

Resumo: O presente artigo faz uma reflexão da nova dimensão da informação no contexto educacional. Abrange os temas educação na Sociedade da Informação e do Conhecimento, acesso à informação, busca, uso da informação e fontes de informação. Sobre a busca e o uso da informação no ambiente educacional discorre sobre o comportamento das crianças na busca da informação e os tipos de fontes de informação adequadas ao ambiente escolar.

CAMPELLO, Bernadete. O movimento da competência informacional: uma perspectiva para o letramento informacional. Ci. Inf., Brasília, v. 32, n. 3, p. 28-37, set./dez. 2003. Disponível em: <

http://revista.ibict.br/ciinf/index.php/ciinf/article/view/26/22>. Acesso em: 18 maio 2009.

Resumo: O objetivo deste trabalho é analisar a competência informacional (information literacy), que surgiu nos Estados Unidos na década de 1970 e representa o esforço da classe bibliotecária americana para ampliar o seu papel dentro das instituições educacionais. O movimento ocorreu em circunstâncias peculiares ao contexto daquele país, acompanhando a evolução das ações educativas da classe bibliotecária. O discurso da competência informacional desenvolve-se ao redor de quatro aspectos: a sociedade da informação, as teorias educacionais construtivistas, a tecnologia da informação e o bibliotecário. Considerando-se que o termo começa a aparecer na literatura brasileira de biblioteconomia e ciência da informação, propõem-se o estudo mais aprofundado do conceito e o estabelecimento de uma agenda de pesquisa para o Brasil, buscando sua inserção nas teorias sobre letramento, que se vêm desenvolvendo na área de educação.

CALDIN, Clarice Fortkamp; FLECK, Felícia de Oliveira. Organização de biblioteca em escola pública: o caso da escola de educação básica Dom Jaime de Barros Câmara. Revista ACB: Biblioteconomia em Santa Catarina, Florianópolis, v. 8/9, p. 155-165, 2003/2004. Disponível em: < http://dici.ibict.br/archive/00000864/01/Rev\%5B1\%5D.AC-2005-99.pdf>. Acesso em: 30 abr. 2009.

Resumo: Relata o mutirão realizado na biblioteca por meio da disciplina Bibliotecas Escolares como originador do projeto de extensão Organização da biblioteca da E.E.B.Dom Jaime de Barros Câmara. Destaca como objetivos do projeto o organizar e o otimizar a biblioteca em questão para que a mesma desempenhe cabalmente as funções educativas, culturais e técnicas. Atuaram no projeto uma professora e uma acadêmica do Curso de Biblioteconomia da Universidade Federal de Santa Catarina. Ativou-se a biblioteca existente, realizou-se o tratamento técnico do acervo, despertou-se o gosto pela leitura, estimulou-se a pesquisa, orientou-se 
as consultas bibliográficas, buscou-se parceria com os professores da Escola. Concluiu-se que o projeto logrou êxito em conscientizar a Direção da Escola da necessidade de contratação de um profissional bibliotecário para a efetiva realização das atividades da biblioteca escolar.

CALDIN, Clarice Fortkamp. Reflexões acerca do bibliotecário de biblioteca escolar. Revista ACB: Biblioteconomia em Santa Catarina, Florianópolis, v. 10, n. 2, p. 163168, 2005. Disponível em: < http://www.acbsc.org.br/revista/index.php/racb/article/viewFile/431/550>. Acesso em: 18 maio 2009.

Resumo: Destaca a importância da biblioteca escolar na difusão e fomento da leitura. Apresenta reflexões acerca das atividades do bibliotecário da biblioteca escolar. Salienta que a seleção do acervo bibliográfico é de sua responsabilidade e competência. Incentiva o bibliotecário a ser um leitor ávido, complementando com autodidatismo suas deficiências literárias com a finalidade de obter cultura geral.

CARVALHO, Carmen Pinheiro de. A biblioteca e os estudantes. Revista da Escola de Biblioteconomia da Universidade Federal de Minas Gerais, v.1, n.2, p. 196-211, jul./dez. 1972.

Resumo: O Papel da biblioteca escolar no processo educacional. Confronto entre as tarefas específicas da biblioteca escolar e da biblioteca pública. Analise da situação atual da Biblioteca Pública de Minas Gerais "Prof. Luis de Bessa", mostrando sua quase transformação em biblioteca escolar para a comunidade estudantil de Belo Horizonte, em detrimento de outras finalidades igualmente importantes. Palestra pronunciada durante a Semana Nacional da Biblioteca em março de 1972.

CARVALHO, Lafaiete da Silva. A leitura na sociedade do conhecimento. Revista ACB: Biblioteconomia em Santa Catarina, Florianópolis, v. 11, n. 1, p.19-27, jan./jul. 2006. Disponível em: < http://www.acbsc.org.br/revista/index.php/racb/article/viewFile/459/576>. Acesso em: 18 maio 2009.

Resumo: Destaca a importância da reflexão sobre as leituras, no sentido de compreender as diversidades cognitivas, educacionais e culturais que perpassam 0 ser humano. O texto tem como objetivo apontar algumas questões sobre leituras, o leitor e as circunstâncias do contexto na Era do Conhecimento. As políticas públicas de acesso e uso da informação são os instrumentos que interferem diretamente na Sociedade da Informação. 
CARVALHO, Maria da Conceição. Uma política de desenvolvimento de coleção para a biblioteca do Instituto de Educação de Minas Gerais. Revista da Escola de Biblioteconomia da Universidade Federal de Minas Gerais, v.9, n.2, p. 195-216, jul./dez. 1980.

Resumo: Considerações gerais sobre o desenvolvimento de coleção em bibliotecas escolares. Proposta de política de desenvolvimento de coleção para a biblioteca do Instituto de Educação de Minas Gerais.

CARVALHO, Maria da Conceição. Educação de usuário em bibliotecas escolares: considerações gerais. Revista de Biblioteconomia de Brasília, Brasília, v.9, n.1, p. 22-29, jan./jun. 1981

Resumo: Discute o valor e os métodos de um programa de educação de usuários em bibliotecas escolares.

CAVALCANTI, Vanessa Oliveira de Macêdo. Biblioteca escolar: espaço de aprendizagem. Pesquisa Brasileira em Ciência da Informação e Biblioteconomia, v. 1, n. 1, 2006. Disponível em: < http://revista.ibict.br/pbcib/index.php/pbcib/issue/view/1>. Acesso em: 18 maio 2009.

Resumo: Apresenta a biblioteca escolar, enfocando sua missão e seus objetivos de acordo com o manifesto da UNESCO/IFLA. Através dos Parâmetros Curriculares Nacionais - PCN mostra a importância do espaço da biblioteca, no desenvolvimento da leitura autônoma e da aprendizagem, bem como as práticas escolares determinadas pela Lei de Diretrizes e Bases da Educação Nacional LDB, na educação básica, caracterizando o espaço da biblioteca escolar como um ambiente de aprendizagem. Destaca a necessidade de competência em informação desde a educação básica, ressaltando o papel do bibliotecário mediador da informação e ser participativo, que em parceria com o professor poderá desenvolver algumas atividades no âmbito da biblioteca, através da pesquisa escolar, contribuindo assim, no processo de aprendizagem. Utiliza como metodologia pesquisa bibliográfica e eletrônica. Conclui-se apontando que a biblioteca escolar cria oportunidades para a aprendizagem se a parceria bibliotecário, professor e equipe pedagógica for bem explorado concretizando, assim, a biblioteca escolar como espaço de aprendizagem

CERDEIRA, Theodolindo. A biblioteca escolar no planejamento educacional. Revista de Biblioteconomia de Brasília, Brasília, v.5, n.1, p. 35-43, jan./jun. 1977.

Resumo: Analisa uma mudança do conceito de biblioteca escolar, através do desenvolvimento tecnológico, com novos recursos de comunicação. Além da função de suporte ao currículo escolar formal, a biblioteca - centro de recursos didáticos - objetiva desenvolver apreciação artística e o aprofundamento do conhecimento científico e tecnológico. Ressalta a importância do processo de planejamento educacional, com um enfoque sistêmico, onde se destaca o sistema 
demográfico, o econômico e o sócio-cultural. Focaliza a biblioteca escolar no contexto de um plano de educação. Nota: Trabalho apresentado nas onze sessões de estudo do $8^{\circ}$ Congresso Brasileiro de Biblioteconomia e Documentação, realizado em Brasília, de 21 a 25 de julho de 1975.

COSTA, Tarcilia Martins da. Biblioteca Escolar do Centro Pedagógico da UFMG. Revista da Escola de Biblioteconomia da Universidade Federal de Minas Gerais, v.4, n.2, p. 278-282, jul./dez. 1975.

Resumo: O papel da biblioteca na escola. Funcionamento da Biblioteca do Centro Pedagógico da UFMG, incluindo atividades da Seção Infantil.

CUARTAS, Graciela D.; CORRÊA, Alba Maria Dourado. Diagnóstico da situação das bibliotecas estaduais pertencentes à $18^{a}$ Delegação de Educação. BIBLOS, v.2, p. 9-15, 1987.

Resumo: Levantamento estatístico que tem por objetivo verificar a situação das bibliotecas escolares da $18^{a}$ Delegacia de Ensino do Rio Grande, para posterior elaboração de um plano de ação que atenda aos interesses da população escolar desse serviço.

DOMINGUES, Fernanda et al. Atividade de leitura na educação especial: uso da biblioteca escolar e brinquedoteca. Revista ACB: Biblioteconomia em Santa Catarina, Florianópolis, v.11, n. 1, p.221-232, jan./jul. 2006. Disponível em: $<$ http://www.acbsc.org.br/revista/index.php/racb/article/viewFile/479/612>. Acesso em: 18 maio 2009.

Resumo: Este artigo trata sobre a prática de leitura para pessoas portadoras de necessidades especiais desenvolvido na Associação de Pais e Amigos dos Excepcionais de Florianópolis (APAE/Florianópolis), através de projeto de extensão do Departamento de Ciência da Informação (CIN), com o apoio do Departamento de Apoio à Extensão (DAEx), da Universidade Federal de Santa Catarina (UFSC). Destacam-se as várias atividades desenvolvidas junto aos alunos da APAE/Florianópolis, ressaltando a importância da leitura e da biblioteca escolar no processo de desenvolvimento de portadores de necessidades especiais.

DUMONT, Márcia Milton Vianna. Bibliotecas escolares comunitárias: uma revisão bibliográfica. Revista da Escola de Biblioteconomia da Universidade Federal de Minas Gerais, v.13, n.2, p. 147-178, jul./dez. 1984.

Resumo: Análise da literatura sobre bibliotecas de dupla finalidade, abrangendo o desenvolvimento histórico, sua conceituação, vantagens e desvantagens, e razões que podem levar ao desenvolvimento e/ou criação desse tipo de instituição. Exame de estudos realizados sobre o tema no estrangeiro e da situação das bibliotecas de dupla finalidade no Brasil. 
EGGERT-STEINDEL, Gisela. Possíveis indícios da biblioteca escolar na rede pública do estado de Santa Catarina: estudo de um acervo bibliográfico museológico. Revista ACB: Biblioteconomia em Santa Catarina, Florianópolis, v. 11, n. 1, p.143-153, jan./jul. 2006. Disponível em: < http://www.acbsc.org.br/revista/index.php/racb/article/viewFile/473/600>. Acesso em: 18 maio 2009.

Resumo: Trata-se de uma pesquisa em andamento, de caráter descritivo e documental abrangendo as áreas da História da Educação, Biblioteconomia e Museologia. Analisa um acervo bibliográfico existente no Museu da Escola Catarinense visando reconhecer alguns aspectos da biblioteca escolar em Santa Catarina na Rede de Ensino Pública.

ELY; Neiva Helena. Dimensões da biblioteca escolar no ensino fundamental. Revista ACB: Biblioteconomia em Santa Catarina, Florianópolis, v. 8/9, p. 46-53, 2003/2004. Disponível em: <http://www.acbsc.org.br/revista/index.php/racb/article/viewFile/405/510>. Acesso em: 18 maio 2009.

Resumo: Considera aspectos da biblioteca escolar e do bibliotecário escolar. Apresenta as dimensões social, informativa, pedagógica, recreativa e criativa da biblioteca escolar no ensino fundamental.

FERRAREZI, Ludmila; ROMÃO, Lucília Maria Sousa. O dizer dos documentos oficiais: a normatização como efeito de sentidos sobre a biblioteca escolar. Revista ACB: Biblioteconomia em Santa Catarina, Florianópolis, v.13, n.2, p.323-346, jul./dez. 2008. Disponível em: $<$ http://www.acbsc.org.br/revista/index.php/racb/article/viewFile/536/666>. Acesso em: 18 maio 2009.

Resumo: Aborda a biblioteca escolar através de uma perspectiva multidisciplinar que envolve as áreas de Ciência da Informação, Análise do Discurso francesa e Educação. Analisa discursivamente, em quatro documentos oficiais sobre a biblioteca escolar, os diferentes sentidos delineados para esta unidade de informação, seus objetivos e formas de constituição no imaginário social. Aponta questões inerentes às relações de poder circulantes no contexto educacional, ao profissional da informação, assim como à legitimação política da biblioteca escolar. FLECK, Felícia; PEREIRA, Magda Chagas. O bibliotecário escolar de Florianópolis e sua relação com a leitura. Revista ACB: Biblioteconomia em Santa Catarina, Florianópolis, v.12, n.2, p. 286-302, jul./dez. 2007. Disponível em: http://www.acbsc.org.br/revista/index.php/racb/article/viewFile/509/654. Acesso em: 18 maio 2009.

Resumo: Pesquisa realizada no ano de 2005 com o objetivo de verificar como ocorreu o processo de formação para a leitura dos profissionais da informação atuantes em bibliotecas escolares de instituições de ensino fundamental da rede pública e privada do município de Florianópolis, procurando conhecer seus hábitos atuais de leitura e a maneira como atuam no processo de constituição de novos 
leitores. Como um dos pressupostos da pesquisa era a de que bons leitores seriam capazes de influenciar de modo positivo na formação de novos leitores, buscou-se verificar em que medida isso acontecia efetivamente no cotidiano das escolas.

FRAGOSO, Graça Maria. Biblioteca escolar - profissão e cidadania. Anais... Revista ACB: Biblioteconomia em Santa Catarina, v. 7, n. 1, 2002. Disponível em: $<$ http://www.acbsc.org.br/revista/index.php/racb/article/viewFile/381/463>. Acesso em: 18 maio 2009.

Resumo: Que a burocracia e a política não consigam emperrar o trabalho dos educadores e dos bibliotecários. Não se pode esperar de braços cruzados pelo "final feliz". É preciso que se somem esforços para que coletivamente possamos atuar como bibliotecários de bibliotecas escolares reais. Aquelas tão sonhadas por todos aqueles que acreditam em educação e leitura como um bem cultural e direito de todo cidadão brasileiro.

FRAGOSO, Graça Maria. Biblioteca na escola - uma relação a ser construída. Revista ACB: Biblioteconomia em Santa Catarina, Florianópolis, v. 10, n.2, p. 169173, jan./dez. 2005. Disponível em: < http://www.acbsc.org.br/revista/index.php/racb/article/viewFile/430/548>. Acesso em: 18 maio 2009.

Resumo: Apresenta reflexões sobre a escola real e a ideal no tempo da globalização. Aponta o papel da biblioteca no ambiente real e no ideal. Mostra o desenvolvimento do indivíduo ao tornar-se cidadão na sociedade da informação.

GARCEZ, Eliane Fioravante; CARPES, Gyance. Gestão da informação na biblioteca escolar. Revista ACB: Biblioteconomia em Santa Catarina, Florianópolis, v.11, n.1, p. 53-73, jan./jul. 2006. Disponível em: $<$ http://www.acbsc.org.br/revista/index.php/racb/article/viewFile/466/588 >. Acesso em: 18 maio 2009.

Resumo: Aborda a importância da gestão da informação no ambiente escolar. Apresenta a contribuição da biblioteca escolar na formação de alunos críticos e geradores de conhecimento. Salienta ser fundamental o trabalho colaborativo das pessoas que integram a comunidade escolar. Defende a necessidade de investimento na área da biblioteca escolar para que a mesma possa alcançar seus objetivos. Aponta que a garantia de investimento na biblioteca escolar contribuirá para a melhoria competitiva das empresas, uma vez que poderão contar com pessoal melhor preparado para o mercado de trabalho. 
GARCEZ, Eliane Fioravante. Sociedade da informação e escola: contribuição das bibliotecas escolares. Revista ACB: Biblioteconomia em Santa Catarina, Florianópolis, v.14, n.1, p.9-26, jan./jun. 2009. Disponível em: $<$ http://www.acbsc.org.br/revista/index.php/racb/article/viewFile/653/721 >. Acesso em: 18 maio 2009.

Resumo: Com o presente artigo busca-se promover algumas reflexões sobre a relação existente entre a Sociedade da Informação (SI) e a escola de Educação básica, especificamente, a de Ensino Fundamental. Entende-se que o estabelecimento de uma política nacional de informação requer seja considerado o desenvolvimento de habilidades e competências que as pessoas precisarão adquirir para sobreviver no mundo globalizado. Neste sentido, deve haver preocupação/ação governamental para a formação de contingente numericamente expressivo de cientistas, e também de cidadãos com condições de acessar, entender e decifrar os conteúdos veiculados na internet e em outras mídias. Portanto, torna-se fundamental repensar sobre o papel da escola numa sociedade onde o uso estratégico da informação é sinal de competitividade. Mas, afinal, como está a pesquisa, o uso da biblioteca e da internet no ambiente escolar? Qual a relação existente entre desenvolvimento tecnológico e o ensino da pesquisa na escola? Considerando as dificuldades por que passam os países desenvolvidos da Europa no estabelecimento de suas políticas de informação, em função da interferência hegemônica norte-americana, busca-se pensar sobre a questão no território brasileiro, em função de sua singularidade territorial, econômica e educacional, por representarem um grande desafio para estabelecer as ações previstas no Programa SocInfo.

GARCEZ, Eliane Fioravante. Avaliação de uso como indicador para a gestão da biblioteca escolar: estudo de caso. Revista ACB: Biblioteconomia em Santa Catarina, Florianópolis, v.12, n.1, p.59-73, jan./jun., 2007. Disponível em: < http://www.acbsc.org.br/revista/index.php/racb/article/viewFile/493/636>. Acesso em: 18 maio 2009.

Resumo: Descreve a Biblioteca do Colégio Policial Militar Feliciano Nunes Pires (CFNP), localizada em Florianópolis. Tem como objetivo verificar se as necessidades de informação de seus usuários são atendidas. Trata-se de um estudo de caso de natureza qualitativa, com caráter descritivo. A coleta de dados foi realizada por meio da aplicação de dois questionários. Os resultados indicaram elevado percentual de uso da biblioteca. Entretanto, a maioria dos usuários está parcialmente satisfeita com os serviços oferecidos. A pesquisa oferece subsídios para que a gestão desta Biblioteca seja discutida e que seus serviços sejam melhorados. 
GASQUE, Kelley Cristine Gonçalves Dias; COSTA, Sely Maria de Souza.

Comportamento dos professores da educação básica na busca da informação para formação continuada. Ci. Inf., Brasília, v. 32, n. 3, p. 54-61, set./dez. 2003.

Disponível em: <http://revista.ibict.br/ciinf/index.php/ciinf/article/view/32/32>.

Acesso em: 18 maio 2009.

Resumo: O estudo objetiva descrever as características dos docentes e identificar os canais e fontes utilizados, assim como os fatores que influenciam o padrão de comportamento na busca da informação para formação continuada. Utilizou-se como referencial teórico o modelo de busca de informação de Wilson, com enfoque nas necessidades cognitivas dos professores, de acordo com o modelo proposto por Imbernón. Os instrumentos de coleta de dados foram o questionário autoadministrado e a entrevista semi-estruturada. Os resultados mostram que as fontes mais usadas são os livros didáticos e paradidáticos, além de jornais. Concluiu-se que as novas tecnologias ainda não são usadas por professores de educação básica como um recurso cotidiano de apoio à formação continuada, e os canais de informação mais utilizados são os arquivos pessoais, arquivos dos colegas e a biblioteca escolar.

HILLESHEIM, Araci Isaltina de Andrade; FACHIN, Gleisy Regina Bories. Conhecer e ser uma biblioteca escolar no ensino-aprendizagem. Revista ACB:

Biblioteconomia em Santa Catarina, Florianópolis, v. 4, n. 4, 1999. Disponível em: <http://www.acbsc.org.br/revista/index.php/racb/article/viewFile/340/403>. Acesso em: 18 maio 2009.

Resumo: Apresenta a Biblioteca Escolar como um recurso didático-pedagógico a ser utilizado para a integração e dinamização do processo ensino-aprendizagem. Arrola conceitos, objetivos e funções da Biblioteca Escolar. Expõe a importância da seleção e aquisição do acervo e também as atividades e serviços oferecidos por esta biblioteca.

KRUEL, Inês Rosito Pinto; SILVEIRA, Itália Maria Falceta da. Biblioteca como laboratório do processo ensino-aprendizagem: uma experiência e cursos de extensão universitária em Porto Alegre. Revista de Biblioteconomia e Comunicação, v.2, p. 36-41, jan./dez., 1987.

Resumo: Relato de experiência em Curso de Extensão Universitária oferecido ao pessoal que atua em Bibliotecas Escolares, não formados em Biblioteconomia. Trabalho apresentado no XII Congresso Brasileiro de Biblioteconomia e Documentação, Camboriú, SC, em 1983.

MACEDO, Neusa Dias de; SIQUEIRA, Idméa Semeghini Próspero. Subsídios para a caracterização da biblioteca escolar. Revista Brasileira de Biblioteconomia e Documentação, v.20, n.1/4, p. 67-69, jan./dez., 1987.

Resumo: Quando sinóptico que descreve a biblioteca escolar dentro do seguinte parâmetro receptor, objetivos/ materiais, serviços- meio, serviços- fim, agentes, 
ambientação física, tendo como intuito servir de subsídio didático para professores e alunos de biblioteconomia.

MACHADO, Raquel. Trabalhando com gêneros literários: relato de experiência na biblioteca do Colégio da Lagoa, em Florianópolis (SC). Revista ACB:

Biblioteconomia em Santa Catarina, Florianópolis, v. 12, n.2, p. 311-321, jul./dez. 2007. Disponível em: <

http://www.acbsc.org.br/revista/index.php/racb/article/viewFile/511/655>. Acesso em: 18 maio 2009.

Resumo: Este artigo relata o trabalho desenvolvido com gêneros literários na biblioteca escolar do Colégio da Lagoa, localizado em Florianópolis (SC). O projeto teve como objetivo reorganizar a coleção de literatura juvenil do colégio a partir dos gêneros literários existentes, bem como servir de incentivo à leitura. Bibliotecário, professores e alunos foram as partes envolvidas no projeto. Apesar de algumas dificuldades encontradas no decorrer das atividades, o projeto foi muito significativo para toda a comunidade escolar, pois despertou o senso crítico dos alunos criando autonomia na hora da escolha do livro de leitura e servindo de instrumento de interação entre usuário e bibliotecário.

MARTUCCI, Elizabeth Márcia. Informação para educação: os novos cenários para o ensino fundamental. Informação e Sociedade: Estudos, Paraíba, v. 10, n. 2, p. 116, 2000. Disponível em: <

http://www.ies.ufpb.br/ojs2/index.php/ies/article/view/325/247>. Acesso em: 30 abr. 2009.

Resumo: A comunidade internacional tem se preocupado com a educação para o século XXI, tendo em vista o novo cenário social advindo da sociedade da informação. A educação fundamental tem sido considerada um "passaporte para a vida", devendo desenvolver, em todas as pessoas, um corpo de conhecimentos essenciais e um conjunto mínimo de competências cognitivas, para que possam viver em ambientes saturados de informações e continuar aprendendo. Esta revisão aborda algumas políticas educacionais, no âmbito internacional, sobre a educação básica e seus reflexos no Brasil, assim como o papel estratégico da biblioteca escolar para o domínio das ferramentas e dos conteúdos da aprendizagem.

MATTOS, Ana Luiza de Oliveira; PINHEIRO, Michele. O perfil das bibliotecas escolares - universitárias (bibliotecas mistas) nas instituições de ensino privado em Santa Catarina. Revista ACB: Biblioteconomia em Santa Catarina, Florianópolis, v. 11, n. 1, p.171-184, jan./jul. 2006. Disponível em: <http://www.acbsc.org.br/revista/index.php/racb/article/viewFile/474/602>. Acesso em: 18 maio 2009.

Resumo: Analisa a legislação brasileira vigente na área da educação. Descreve aspectos dos perfis já conhecidos de bibliotecas escolares e universitárias por meio da bibliografia existente. Busca identificar as causas das escolas da rede privada 
de ensino de Santa Catarina terem investido também nos últimos anos em ensino superior, procurando apontar fatores políticos, econômicos e sociais que acarretaram o crescimento do ensino superior no país. Define o perfil da biblioteca escolar-universitária e sugere alternativas de gerenciamento da informação.

MENDONÇA, Fernando de. A estrada da vida: a leitura e a biblioteca escolar no ensino. Revista ACB: Biblioteconomia em Santa Catarina, Florianópolis, v. 13, n.2, p.379-389, jul./dez., 2008. Disponível em: < http://www.acbsc.org.br/revista/index.php/racb/article/viewFile/573/692>. Acesso em: 18 maio 2009.

Resumo: Analisa a importância da leitura para o ser humano como prática social, indagando conceitos que definam a mesma e apontando a situação da leitura e da escrita no Brasil. Compreende a organização de uma biblioteca escolar como um meio de disseminação da leitura entre os estudantes. Destaca a importância de todos os envolvidos com a instituição escolar para o bom funcionamento de sua biblioteca. O bibliotecário, a direção da escola, os professores e os próprios alunos são agentes que devem trabalhar em conjunto, pois só assim uma consciência cidadã será formada na vida desses alunos.

MORETTI, Dina Maria Bueno et al. GIEB: uma experiência de integração escolabiblioteca. Revista de Biblioteconomia de Brasília, Brasília, v.5, n.2, p. 685-691, jul./dez. 1977.

Resumo: A preocupação com a situação da Biblioteca escolar, em Piracicaba, deu origem ao Curso de difusão de Biblioteca. Dirigido a professores de escolas de $1^{\circ} \mathrm{e}$ $2^{\circ}$ graus teve por objetivo o incentivo à criação e dinamização das Bibliotecas nas suas instituições. A motivação alcançada ocasionou a formação do Grupo de Integração Escola-Biblioteca (GIEB), composto de bibliotecários e professores. O plano do GIEB para o $1^{\circ}$ ano de atividades se resumiu em cinco projetos, atingindo o pré-escolar, $1^{\circ}$ e $2^{\circ}$ graus. O decreto do governador do estado de São Paulo veio de encontro aos objetivos do Grupo, pois determina a criação do cargo de bibliotecário nas escolas de $1^{\circ}$ e $2^{\circ}$ graus com mais de vinte classes.

OLIVEIRA, Tereza da Silva Freitas. A biblioteca escolar no regimento comum das escolas de $1^{\circ}$ e $2^{\circ}$ graus do Estado de São Paulo. Revista Brasileira de Biblioteconomia e Documentação, v.12, n.3/4, p. 231-238, jul./dez. 1979.

Resumo: A biblioteca escolar como unidade integrante do núcleo de Apoio Técnico Pedagógico no Regimento das Escolas de $1^{\circ}$ e $2^{\circ}$ graus no Estado de São Paulo. Integração do bibliotecário nos planejamentos e programações escolares. O relacionamento que se almeja no processo de ensino-aprendizagem. 
PACHECO, Rachel. Incentivo ao uso nas series iniciais: relato de experiência.

Revista ACB: Biblioteconomia em Santa Catarina, Florianópolis, v. 12, n. 2, p. 303310, jul./dez. 2007. Disponível em:

<http://www.acbsc.org.br/revista/index.php/racb/article/viewFile/502/648. $>$ Acesso em: 18 maio 2009.

Resumo: Relata a experiência das atividades educacionais desenvolvidas no ambiente da Biblioteca Escolar Monteiro Lobato da Escola Desdobrada Retiro da Lagoa da Prefeitura Municipal de Florianópolis, com alunos de séries iniciais. Intenta levar as crianças a compreenderem que o acervo da biblioteca é organizado em determinada ordem favorecendo o desenvolvimento de habilidades e capacidades para a sua adequada utilização. Como resultado, constatou-se maior socialização das crianças, o desenvolvimento das suas aptidões e senso de responsabilidade, promovendo o uso autônomo da biblioteca e a manifestação de solidariedade.

PERES, Luiz Carlos; SILVEIRA, Maria Inês da. Seleção, aquisição e descarte de materiais de informação para bibliotecas escolares: uma sugestão coerente com a atual realidade escolar. Revista ACB: Biblioteconomia em Santa Catarina, Florianópolis, v. 3, n. 3, 1998. Disponível em: < http://www.acbsc.org.br/revista/index.php/racb/article/viewFile/333/395>. Acesso em: 18 maio 2009.

Resumo: O presente artigo objetiva servir como uma fonte a mais de consulta para elaboração de manuais de política de seleção, aquisição e descarte de materiais de informação de biblioteca escolar, considerando $A$ realidade das escolas catarinenses em geral, bem como os materiais que freqüentemente formam seus acervos.

PERUCCHI, Valmira. A importância da biblioteca nas escolas públicas de Criciúma - Santa Catarina. Revista ACB: Biblioteconomia em Santa Catarina, Florianópolis, v. 4, n. 4, 1999. Disponível em: < http://www.acbsc.org.br/revista/index.php/racb/article/viewFile/341/404>. Acesso em: 18 jan. 2009.

Resumo: Este estudo ressalta a importância da biblioteca no contexto escolar, tendendo as exigências do currículo, incentivando 0 hábito de leitura, desenvolvendo a capacidade da pesquisa, tratando assim, de aumentar o nível de conhecimento dos seus usuários. Sugere propostas para a organização dos serviços da biblioteca escolar. Esta pesquisa analisou a importância e a situação de funcionamento das bibliotecas nas escolas Públicas Municipais de Criciúma Santa Catarina, através de entrevista com diretores e responsáveis pela biblioteca de quatro (4) Escolas Públicas Municipais. 
PIMENTEL, Cléa Dubeux Pinto. Programa para criação e instalação de bibliotecas escolares na rede de ensino oficial. Revista de Biblioteconomia de Brasília, v.5, n.2, p. 693-705, jul./dez. 1977.

Resumo: Dados históricos sobre o desenvolvimento do Nordeste e promoção da educação em Pernambuco. Situação das bibliotecas nesse Estado e proposta de criação de uma rede de bibliotecas escolares para atender aos estudantes da capital e do interior. Análise e funcionamento do programa recursos humanos, treinamento, etc. Propõe a criação, pelos governos, de instrumentos para instalação do programa Plano Nacional de Bibliotecas Públicas e Escolares.

POLKE, Ana Maria Athayde. A Biblioteca Escolar e o seu papel na informação de hábitos de leitura. Revista da Escola de Biblioteconomia da Universidade Federal de Minas Gerais, v.2, n.1, p. 60-72, jan./jun. 1973.

Resumo: Discussão das razões da não existência de bibliotecas escolares operantes no país. Escola Polivalente como estímulo à implantação de bibliotecas junto às demais escolas. Papel educativo da Biblioteca Escolar. Nota: Aula proferida em outubro de 1972 para a disciplina Estudo de Problemas Brasileiros. RAMALHO, Maria Olinda Horta. O silêncio na biblioteca escolar: necessidade ou mito?. Revista de Biblioteconomia e Comunicação, v.3, p. 87-90, jan./dez., 1988.

Resumo: O silêncio nas bibliotecas escolares muitas vezes se torna um obstáculo à presença dos alunos, no caso crianças e adolescentes, cujas características personalógicas se chocam com a exigência de disciplina, rigidez e silêncio de uma biblioteca.

RIBEIRO, Maria Solange Pereira. Desenvolvimento de coleção na biblioteca escolar: uma contribuição à formação crítica sócio-cultural do educando. Transinformação, v.6, n.1/3, p. 60-73, jan./dez. 1994.

Resumo: O objetivo foi analisar a coleção de História do Brasil de $5^{\mathrm{a}} \mathrm{s} 6^{\mathrm{a}}$ serie do $1^{\circ}$ grau existente nas bibliotecas escolares. O foco da análise foi a presença do negro na referida coleção. Para tanto foi utilizada a análise psicolingüística a qual busca descrever o sentido dos verbos nos aspectos denotativo e conotativo nas categorias: social, cognitivo, afetivo e física. A pesquisa apresenta ainda sugestões para selecionar o livro infanto-juvenil, fornecendo ao professor e bibliotecário subsídios para o desenvolvimento da coleção escolar.

SANTOS, Inácia Rodrigues dos. A biblioteca escolar e atual pedagogia brasileira. Revista de Biblioteconomia de Brasília, Brasília, v.1, n.2, p. 145-149, jul./dez. 1973.

Resumo: Estando superado o conceito tradicional de que a biblioteca escolar seria um depósito de livros para suplementar o programa de estudos, sua função passa a ser a de um centro de informação e cultura, onde se inclui o processamento e a utilização dos mais diversos tipos de documentos e recursos audiovisuais. Essa nova função, no entanto, ainda é ignorada no Brasil, estando muitas bibliotecas 
escolares, das poucas que existem, funcionando de maneira precária. Para que a biblioteca escolar se integre no ensino preconizado pela nova pedagogia, o bibliotecário deverá transformar-se num verdadeiro especialista da pesquisa e da leitura e capaz de se entrosar e colaborar com os diferentes especialistas da Educação.

SILVEIRA, Itália Maria Falceta da. Ensinar a pensar: uma atividade da biblioteca escolar. Revista de Biblioteconomia e Comunicação, v.7, p. 9-30, jan./dez., 1996.

Resumo: Apresenta exemplificação sobre a utilização das categorias pensamento, propostas por Louis Raths e seus colaboradores, como situação de aprendizagem da biblioteca escolar para crianças do jardim de infância e primeiras séries do primeiro grau.

SILVEIRA, Lúcia da; FIORAVANTE, Rosane; VITORINO, Elizete Vieira. Formação e desenvolvimento de coleções: proposta para biblioteca escolar de acordo com a pedagogia Waldorf. Revista ACB: Biblioteconomia em Santa Catarina, Florianópolis, v. 14, n. 1, p. 86-103, jan./jun. 2009. Disponível em: < http://www.acbsc.org.br/revista/index.php/racb/article/viewFile/663/731>. Acesso em: 19 fev. 2009.

Resumo: Apresenta o relato de experiência realizado no ano de 2008 com propósito de conhecer o acervo da Biblioteca da Escola Waldorf Anabá de Florianópolis-SC. Trata do tema desenvolvimento de coleções sob o prisma da Biblioteca Escolar e insere a pedagogia Waldorf neste contexto. Descreve as políticas e culturas desta instituição, principalmente com relação ao ensinoaprendizagem. Caracteriza a situação do acervo por meio de visita in loco bem como entrevista semi-estruturada. Apresenta sugestões de incorporação de novos títulos ao acervo. Identifica o bibliotecário como um diferencial na gestão da Biblioteca Escolar.

SIQUEIRA; Idméa Semeghini Próspero. Projeto ARTE-IN: preparando o ArteEducador para interagir nas programações da biblioteca escolar. Revista Brasileira de Biblioteconomia e Documentação, v.20, n.1/4, p. 45-66, jan./dez. 1987.

Resumo: No Projeto ARTE-IN, cinco etapas se delineiam: 1) conhecimento da produção editorial de livros de ARTE Visual Literatura Infantil; 2) discussão de aspectos teóricos, concernentes à arte, leitura e literatura infantil; 3) criação e produção de livros pelos alunos do $3^{\circ}$ grau; 4) simulação de atividades que poderão ser realizadas com crianças, a partir do livro em questão; 5) debates sobre o espaço em que as atividades serão desenvolvidas na Biblioteca Escolar. Utilizando o livro em questão e interagindo com o bibliotecário na Biblioteca Escolar, o arte- educador possibilita a efetivação da ação cultural. 
SOUSA, Wanda Lucia Schimdt e. Sistema de documentação: experiência do SENAI-SP. Transinformação, v.2, n.1, p. 25-36, jan./abr. 1990.

Resumo: Situa o SENAI e a documentação nesta entidade. Detalha o projeto de implantação e desenvolvimento de Centros de Documentação e Recursos Didáticos em Escolas, em implementação no SENAI-SP, desde 1988.

VÁLIO, Else Benetti Marques. Biblioteca escolar: uma visão histórica. Transinformação, v.2, n.1, p. 15-24, jan./abr. 1990.

Resumo: Este artigo tenciona procurar entender a biblioteca escolar, quando de promoção da leitura, tendo em vista uma breve análise histórica desde o início da colonização brasileira.

UNIVERSIDADE DE BRASÍLIA (UNB). Elementos básicos para a organização de bibliotecas escolares. Cadernos de Biblioteconomia, Arquivística e Documentação, v.9, n.3/4, p. 175-200, jul./out. 1972.

Resumo: Orientações gerais para a organização duma biblioteca escolar liceal; orientações sucintas e acessíveis de modo a poderem ser utilizadas directamente pelos seus encarregados. Considera-se primeiro o problema da implantação e da equipe responsável, passando-se, em nova secção, aos problemas de leitura, atracção de leitores e actividades complementares. Os aspectos técnicos, com os seus circuitos marcados, são apresentados em duas seções, correspondendo respectivamente a livros e a publicações periódicas.

\subsection{Livros:}

ANTUNES, Walda de Andrade. O que é: biblioteca pública municipal, biblioteca escolar e sala de leitura- uma conversa com o prefeito municipal. Brasília: Inl, 1989. $24 \mathrm{p}$.

Palavras-chave: bibliotecas de escolas elementares; bibliotecas de escolas primárias; bibliotecas escolares; bibliotecas públicas.

ANTUNES, Walda de Andrade. Biblioteca escolar: curso de atualização para professores -- manual. 2. ed. rev. e ampl. São Paulo: Global, 2007. 224 p.

Sumário: o professor regente de biblioteca; organização e dinamização da biblioteca escolar; uso da informação; promoção da leitura; videoteca; a biblioteca escolar do ensino médio. 
ANTUNES, Walda de Andrade. Curso de capacitação do professor regente de biblioteca. Brasília: Walda Antunes Consultorias, 1993. 222 p.

Palavra-chave: bibliotecas escolares.

\section{ASSOCIAÇÃO DOS BIBLIOTECÁRIOS DO DISTRITO FEDERAL. Bibliotecas} públicas e escolares. Brasília: ABDF, 1982. 91 p.

Palavras-chave: bibliotecas de escolas elementares; bibliotecas de escolas primárias; bibliotecas escolares; bibliotecas públicas; conferências; congressos e convenções; seminários.

CALDAS, Maria Aparecida Esteves; SILVA, Sinézia Cecília Araújo; RAMIRES, Gilka Ferreira Gomes. Pesquisa escolar: conhecimento e utilização das fontes bibliográficas. Recife: Bagaço, 1995. 132 p.

Palavras-chave: bibliotecas escolares; fontes de informação; pesquisa escolar.

CAMPELLO, Bernadete et al. Biblioteca escolar: temas para uma prática pedagógica. 2. ed. Belo Horizonte: Autêntica, 2005. 64 p.

Sumário: trata do papel da biblioteca segundo os Parâmetros Curriculares Nacionais, da pesquisa escolar, da internet na biblioteca e na pesquisa escolar, do espaço físico, da coleção, da educação infantil na biblioteca escolar, entre outros.

CAMPELLO, Bernadete. Letramento informacional: função educativa do bibliotecário na escola. Belo Horizonte: Autêntica. 80 p. Disponível em: http://www.autenticaeditora.com.br/livros/item/491>. Acesso em: 28 maio 2009.

Conteúdo: Voltado especialmente para bibliotecários, educadores e dirigentes educacionais, este livro mostra a relação entre o letramento informacional e a educação. Partindo do pressuposto de que cabe ao bibliotecário tornar mais fácil o acesso do indivíduo à informação e, conseqüentemente, ao conhecimento, Bernadete Campello traz nesta publicação reflexões sobre o universo informacional complexo que caracteriza a sociedade contemporânea e sobre a necessidade de preparar as pessoas para aprender de maneira independente com as informações. Além do contato com o mundo das publicações impressas, a Biblioteconomia passa, com a chegada das novas tecnologias, a desenvolver metodologias para organizar estoques de informação no ambiente virtual e a se preocupar em desenvolver nos estudantes habilidades para utilizar efetivamente as informações disponíveis, o que mostra como o campo de estudo vem se adaptando às novas realidades. Atual, este livro reúne em sete capítulos discussões acerca da necessidade da interface entre a Biblioteconomia, a Ciência da Informação e a Educação, numa interdisciplinaridade que propicia um trabalho colaborativo de professores e bibliotecários. Conteúdo retirado do site da Autêntica Editora. 
CANÇADO, Dinorá Couto. Revolucionando bibliotecas. Brasília: Thesaurus, 1997. $232 \mathrm{p}$

Palavras-chave: bibliotecas escolares - Distrito Federal (Brasil); interesses na leitura -- Distrito Federal (Brasil); Distrito Federal (Brasil) - biografia.

DOUGLAS, Mary. A biblioteca da escola primária e suas funções. Rio de Janeiro: INL, 1971. 117 p.

Palavras-chave: bibliotecas de escolas elementares; bibliotecas de escolas primárias; bibliotecas escolares.

FONSECA, Edson Nery da. A biblioteca escolar e a crise da educacão. São Paulo: Pioneira, 1983. 19 p.

Palavras-chave: bibliotecas de escolas elementares; bibliotecas de escolas primárias; bibliotecas escolares.

GARCIA, Edson Gabriel; NERY, Alfredina et al. Biblioteca escolar: estrutura e funcionamento. 3. ed. São Paulo: Loyola, 1989. 108 p. (Práticas pedagógicas, 3). Disponível em: <

http://www.submarino.com.br/produto/1/122777/biblioteca+escolar:+estrutura+e+fu ncionamento?menuld=1174>. Acesso em: 28 maio 2009.

Conteúdo: Esta é uma coletânea de textos diferentes que discutem a estrutura ideal e real das bibliotecas escolares - e seus similares - bem como sua prática possível aqui agora. São perspectivas diferentes que vão desde a justificativa da necessidade das bibliotecas escolares até a questão dos multimeios. Fonte: site Submarino.

GARCIA, Edson Gabriel. Leitura na escola de $1^{\circ}$ grau. 2. ed. São Paulo: Loyola, 1988. 88 p. (Práticas pedagógicas, 1). Nota: trechos do livro disponíveis no Google books. Disponível em: http://books.google.com.br/books?id=omDJXRbj7gC\&pg=PA13\&dq=Leitura+na+escola+de+1\%C2\%BA+grau. $+2 .+$ ed\#PPA7 ,M1. Acesso em: 30 abr. 2009.

Conteúdo: leitura: idéias, discussão e teoria; leitura: propostas, discussões e prática. 
LEAHY, Cyana. A leitura e o leitor integral: lendo na biblioteca da escola. Belo Horizonte: Autêntica, 2007, 112 p. Fonte: Livraria Siciliano. Disponível em: $<$ http://www.siciliano.com.br/produto/produto.dll/detalhe?pro id=1579552\&ID=BD1 B08C37D9051A0F372D0833\&FIL ID=102>. Acesso em: 28 maio 2009.

Conteúdo: "Desenvolver a prática literária em escolas públicas significa reconstruir a história junto a uma nova geração de alunos, oriundos de diferentes estratos sociais. O exercício da leitura é uma ferramenta de transformação e socialização, especialmente para crianças e pré-adolescentes. Neste livro, a autora aposta, ainda, na necessidade dos educadores se enxergarem como uma ponte entre o livro e o aluno. Conscientes, devem rever a importância do ato de ler nas escolas, bem como o papel dessa prática na constituição de cidadãos".

MACEDO, Neusa Dias de; SEMEGHINI-SIQUEIRA, Idméa. Biblioteca publica/biblioteca escolar de país em desenvolvimento: diálogo entre bibliotecária e professora para reconstrução de significados com base no manifesto da Unesco. São Paulo: Conselho Regional de Biblioteconomia. 53 p.

Palavras-chave: bibliotecas públicas; bibliotecas escolares.

MACEDO, Neusa Dias de (Org.). Biblioteca escolar brasileira em debate: da memória profissional a um fórum virtual. São Paulo: Editora SENAC; Conselho Regional de Biblioteconomia 8a Região.

Conteúdo: o projeto; contextualização da biblioteca escolar; parâmetros: fórum de debates sobre a biblioteca escolar brasileira, com base no Manifesto Unesco/Ifla (missão; objetivos; financiamento, legislação e redes; bibliotecário e projeto político-pedagógico; recursos informativos: acervo; recursos humanos; serviços e gestão).

MARTINEZ, Lucila; CALVI, Gian. Escola, sala de leitura e biblioteca criativa: o espaço da comunidade. 5. ed. [s. I.]: Autores e Agentes e Associados. 112 p. (Col. Crianças Criativas). Disponível em: <

http://www.criancascriativas.com.br/site/livros3.asp?cod=22>. Acesso em: 28 maio 2009.

Conteúdo: As estratégias de Gerência Criativa num manual prático com as orientações de marketing necessárias para o dia-a-dia de educadores, bibliotecários e promotores sociais. É um estímulo às ações promocionais orientadas para a relação escola/comunidade. Os autores nos transmitem as experiências vividas na coordenação e implantação de serviços nacionais de informação e bibliotecas públicas e escolares, bem como na implementação de projetos de comunicação e criação de materiais educativos. Inclui a Lei de Diretrizes e Bases da Educação Nacional e os Fundamentos dos Parâmetros Curriculares Nacionais. Fonte: site Crianças Criativas. 
PEREIRA, Andréa Kluge; NÓBREGA Maria José. Biblioteca na escola. Brasília: Secretária de Educação Básica - MEC, 2006. 57 p. Disponível em:

$<$ http://portal.mec.gov.br/seb/arquivos/pdf/Avalmat/polleit biblio.pdf>. Acesso em:

28 maio 2009.

Conteúdo: o livro discorre sobre a formação de leitores autônomos, o espaço de leitura, o espaço de leitura, as várias possibilidades da leitura, a apropriação do texto escrito, ampliando as leituras - algumas possibilidades, o que pode fazer a escola, Conhecendo um pouco mais.

PORTELA, Nídia Maria Lubisco. Acervo básico para bibliotecas escolares do primeiro grau. Salvador: Fundo de Cultura do Estado da Bahia, 1982. 120 p.

Palavras-chave: biblioteconomia; bibliotecas de escolas elementares; bibliotecas de escolas primárias; bibliotecas escolares; desenvolvimento de coleções: processos técnicos: biblioteconomia; desenvolvimento do acervo: processos técnicos: biblioteconomia.

RABELLO, Branca Tamm. Sistema integrado de bibliotecas escolares. Brasília: Governo do Distrito Federal, $37 \mathrm{p}$.

Palavras-chave: bibliotecas de escolas elementares; bibliotecas de escolas primárias; bibliotecas escolares; Brasília: Distrito Federal: Brasil; centros de documentação; serviços de documentação; serviços de informação: documentação; sistemas de informação: documentação.

SILVA, Ezequiel Theodoro da. Leitura na escola e na biblioteca. 5. ed. [s. I]: Papirus, 1995. Fonte: Livraria Leitura. Disponível em: < http://www.livrariacultura.com.br/scripts/cultura/resenha/resenha.asp?nitem=21907 9\&sid=01221395011416504621381660\&k5=33ACD0B3\&uid=>. Acesso em: 28 maio 2009.

Conteúdo: Nesse livro, o autor aprofunda e discute as condições de produção da leitura na sociedade brasileira, dando ênfase ao trabalho realizado por professores e bibliotecários. Todo bom leitor é conseqüência da atmosfera reinante no seu contexto social, principalmente daquela presente na escola e na biblioteca.

SILVA, Rovilson; BORTOLIN, Sueli (org.). Fazeres cotidianos na biblioteca escolar. São Paulo: Polis, 2006. 118 p. Disponível em: < http://www.uel.br/revistas/uel/index.php/informacao/article/view/1740/1489>.

Acesso em: 28 maio 2009.

Conteúdo: A obra é produto do esforço de vários autores, com experiência variada na área, unidos pela preocupação de trazer uma contribuição útil, um repensar a situação da biblioteca escolar. Os textos apresentados tratam da matéria de forma simples, clara, direta, em linguagem acessível a leigos, podendo ser útil não 
apenas para o profissional da área, mas também para as equipes pedagógicas das escolas, diretores e mesmos pais que podem ser envolvidos no compromisso de melhorar a qualidade de ensino. Biblioteca escolar deve ser uma cobrança para que se busque a sonhada melhoria e se possa formar melhor a cidadania. Trecho extraído da resenha elaborada por Geraldina Porto Witter (2006).

SILVA, Waldeck Carneiro da. Miséria da biblioteca escolar. São Paulo: Cortez, 1995. 118.

Sumário: O livro trata da utilização da biblioteca escolar no ensino-aprendizagem segundo os livros de didática, dos obstáculos ao uso da biblioteca na escola brasileira e do seu potencial de uso, do vigor da biblioteca escolar como tema de pesquisa. Traz reflexões sobre alternativas para a biblioteca escolar brasileira, a biblioteca escolar e a formação do educador, a organização de eventos, cotidiano pedagógico e este tipo de biblioteca, sua direção e seu cotidiano.

SILVA, Waldeck Carneiro da. Miséria da biblioteca escolar. 2. ed. São Paulo: Cortez, 1999. 119 p.

Palavras-chave: Brasil; bibliotecas de escolas elementares; bibliotecas de escolas primárias; bibliotecas escolares.

SIMÃO, Maria Antonieta Rodrigues. Ativando a biblioteca escolar: [recursos visuais para implementar a interação biblioteca-usuário]. Porto Alegre: Sagra-Luzzatto, 1993. $67 \mathrm{p}$.

Palavras-chave: bibliotecas de escolas elementares; bibliotecas de escolas primárias; bibliotecas escolares.

TAVARES, Denise Fernandes. A biblioteca escolar: conceituação, organização e funcionamento, orientação do leitor e do professor. São Paulo: LISA, 1973. 161 p.

Palavras-chave: bibliotecas de escolas elementares; bibliotecas de escolas primárias; bibliotecas escolares.

\subsection{Sites e Base de dados:}

GEBE. Grupo de Estudos sobre Biblioteca Escolar da Escola de Ciência da Informação da UFMG. Disponível em: http://www.eci.ufmg.br/gebe. Acesso em: 05 maio 2009.

Contêm artigos, trabalhos apresentados em seminários, publicações desenvolvidas pelos componentes do grupo, os nomes dos integrantes, traz uma lista com os nomes dos profissionais que estão se destacando na área de biblioteca escolar. 
GRUPO DE BIBLIOTECÁRIOS DA ÁREA ESCOLAR DE SANTA CATARINA GBAE/SC. Disponível em: <http://gbaesc.acbsc.org.br/apresentacao.htm>. Acesso em: 24 maio 2009.

De acordo com um trecho extraído do próprio site: "O Grupo de Bibliotecários da Área Escolar de Santa Catarina - GBAE/SC, foi instituído no dia 7 de julho de 1999, movido pelo desejo de alguns bibliotecários, que compartilhavam da idéia de aproximar os profissionais que atuavam nas instituições de ensino de Santa Catarina, buscando fortalecer a classe bibliotecária, facilitar a troca de experiências e procurar garantir a inclusão e a participação do bibliotecário no contexto escolar".

LIBES. Literatura Brasileira em Biblioteca escolar. Disponível em: http://www.eci.ufmg.br/gebe/libes/. Acesso em: 05 maio 2009.

“LIBES é uma base de dados que reúne referências de documentos sobre biblioteca escolar produzidos no Brasil, principalmente a partir da década de 1960. Inclui artigos de periódicos, dissertações, teses e trabalhos apresentados em eventos, a maioria deles presentes no acervo da Biblioteca Etelvina Lima, da Escola de Ciência da Informação da UFMG".

\subsection{Teses e Dissertações:}

AMARAL, Renilda Gonçalves do. A função da biblioteca pública escolar no contexto da formação integral do educando: estudo de caso. Brasília: Universidade de Brasília, Faculdade de Economia, Administração, Contabilidade e Ciência da Informação e Documentação, Departamento de Ciência da Informação e Documentação, 2008. 99 f. Dissertação. Disponível em: < http://bdtd.bce.unb.br/tedesimplificado/tde busca/arquivo.php?codArquivo=3437>. Acesso em: 28 maio 2009.

Resumo: A pesquisa A função da biblioteca pública escolar no contexto da formação integral do educando: estudo de caso partiu da observação de que a circulação da informação é fator de importância na linguagem e que a experi-ência discursiva dos usuários é fundamental para ajudá-los a tornarem-se mais conscientes da prática em que estão envolvidos como produtores e consumidores de texto. Diante disso, o presente estudo abordou o significado da biblioteca pública escolar no contexto pedagógico e verificou as diferentes conotações desse significado na formação do comportamento intelectual dos alunos, professores, servidores e comunidade. O objetivo central foi analisar de que modo a biblioteca escolar do Centro de Ensino Fundamental 03 de Brasília, denominada Biblioteca Juscelino Kubitschek de Oliveira, configurava-se como mediadora entre professor (ensino) e aluno (aprendizagem) Tal preocupação é indispensável para redimensionar o papel da biblioteca. A bibliografia consultada sobre bibliotecas escolares, Campello (2003), Vidal (2000), Fragoso (2002), Baptista (2007), Antunes (1988), serviu de base conceitual para a proposta desta pesquisa. Contribuíram também para a sustentação do estudo Saracevic (1996), Morin (2001), Assman (2000), Burke (2003), entre outros teóricos. Para a consecução dos objetivos planejados, utilizou-se a pesquisa bibliográfica, que se constituiu de produções 
escritas ou documentadas sobre bibliotecas públicas e escolares, com o propósito de elucidar as fontes e analisá-las. A pesquisa teve propósito descritivo, como também os procedimentos centraram-se no estudo de caso, o qual consistiu em conhecer as condições de gerenciamento dos serviços de informações no Centro de Ensino Fundamental 03 de Brasília.

ANTUNES, Walda de Andrade. Acesso e uso da informação pelo professor da quarta série do primeiro grau da rede municipal de ensino de Uruguaiana, RS: Um estudo de caso. Brasília: Universidade de Brasília?, 1987. 131 f.

Palavras-chave: bibliotecas de escolas elementares; bibliotecas de escolas primárias; bibliotecas escolares.

BARROS, Lucimar Martins de. A biblioteca escolar no planejamento educacional: análise em escolas públicas de $1^{\circ}$ e $2^{\circ}$ graus em Recife/PE. Universidade Federal da Paraíba: João Pessoa, 1998. (dissertação)

Resumo: Aborda a situação das bibliotecas em escolas públicas de $1^{\circ}$ e $2^{\circ}$ graus em Recife-PE, analisando sua real situação de funcionamento, instalações físicas, qualificação de pessoal, formação de acervo, bem como sua integração com o corpo docente, atividades pedagógico-culturais e alunos. Tendo em vista que estas bibliotecas são consideradas elementos de grande importância nos Planos Estaduais de Educação, suas condições são analisadas conjuntamente com as propostas do governo estadual de melhoria e apoio às mesmas, visando comparar as ações apresentadas nos planos e a concretização destas ações. O estudo foi realizado em 15 escolas escolhidas conforme critérios determinados na metodologia, na cidade de Recife-PE, no período de março de 1995 a outubro de 1996, onde foram aplicados questionários entre diretores, alunos e responsáveis por bibliotecas e a partir dos resultados obtidos, foi feita análise das propostas dos planos de educação e da fala dos três grupos de atores da pesquisa, mencionados acima, tomando-se como base o referencial teórico, fazendo-se destaque ao livro "A miséria da Biblioteca Escolar". Os resultados obtidos na pesquisa revelam que as bibliotecas em escolas públicas de $1^{\circ}$ e $2^{\circ}$ graus em Recife têm sofrido alterações positivas, possuindo pessoal treinado e qualificado para exercer a função de regente da biblioteca, bem como desenvolvido trabalhos didáticopedagógico e culturais junto com professores e direção da escola. É reconhecida a preocupação dos governantes, no que se refere a incluir a biblioteca escolar no planejamento educacional, contudo algumas metas de melhorias não foram alcançadas completamente. Constata-se a importância que estas bibliotecas têm frente ao seu público o que torna imprescindível sua presença dentro da escola, fato justificado pela comprovação de que são instrumentos de apoio pedagógicocultural a favor do ensino.

DIOS, Cyana M. Leahy. A dinamização da leitura na biblioteca escolar. Niterói: Faculdade de Educação, Universidade Federal Fluminense, 1989. (dissertação)

Palavras-chave: leitura, biblioteca escolar. 
ELY, Neiva Helena. Biblioteca escolar em escolas públicas estaduais de $1^{\circ} \mathrm{grau}$ : um estudo sobre a atualização, adequação e utilização da coleção de livros. Porto Alegre: Faculdade de Educação, Pontifícia Universidade Católica do Rio Grande do Sul, 1988. (dissertação).

Resumo: Este estudo teve como propósito investigar a qualidade de dez bibliotecas de escolas públicas estaduais de $1^{\circ}$ grau, na cidade de Porto Alegre, RS. Para atingir este objetivo as bibliotecas foram inicialmente caracterizadas quanto às suas instalações, recursos e serviços. A seguir, realizou-se um levantamento, em cinco das dez bibliotecas investigadas com a finalidade de verificar a atualização, adequação e utilização das suas coleções de livros constituídos de 7.662 títulos em 10836 volumes. Os resultados revelaram que a idade da coleção de livros destas bibliotecas distribui-se com 6\% publicados até 1963, cerca de 54\% entre 1964 e 1981 e cerca de 30\% publicados entre 1974 e 1981, enquanto cerca de 37\% não apresentam data de publicação. A seleção da coleção de livros é realizada pelo professor responsável pela biblioteca que, muitas vezes, consulta os professores da escola. A adequação da coleção de livros apresenta-se nas classes: 100 Filosofia, 200 Religião, 300 Ciências Sociais, 400 Filologia e as maiores deficiências encontram-se nas classes 000 Generalidades, 600 Ciências aplicadas, 800 Literatura, 900 Geografia. História e a letra "J", utilizada para Literatura InfantoJuvenil. Observou-se a média de 3,6 volumes por aluno matriculado nestas bibliotecas. Verificou-se que não existe relação entre o tempo de funcionamento da biblioteca e o número de volumes por aluno matriculado. A utilização da coleção de livros destas bibliotecas destaca-se nas classes 900 Geografia. História, letra "J" para Literatura Infanto-Juvenil, 300 Ciências Sociais, 800 Literatura e 500 ciências Puras. Registrou-se a opinião dos responsáveis pelas bibliotecas investigadas quanto aos fatores que contribuem negativamente para a adequação do acervo. Entre as recomendações do estudo incluem-se sugestões visando ao desenvolvimento da coleção de livros de Literatura Infanto-Juvenil e à realização de outros estudos sobre a biblioteca escolar no $1^{\circ} \mathrm{grau}$.

FURTADO, Cássia Cordeiro. A biblioteca escolar brasileira no sistema educacional da sociedade da informação. Brasília: [Universidade de Brasília ?] , 2000. 123 f. (tese)

Palavras-chave: educação; bibliotecas escolares; biblioteconomia; Brasil: geografia; projetos: métodos: administração.

GASGUE, Kelley Cristine Gonçalves Dias. Comportamento dos professores da educação básica na busca de informação para a formação continuada: estudo de caso dos colégios maristas. Brasília: CID - UnB, 2003. 180 f. (tese).

Palavras-chave: bibliotecas como meio educacional; bibliotecas de escolas elementares; bibliotecas de escolas secundárias; bibliotecas escolares; educação na escola; informação profissional: educação; professores: formação; professores: formação profissional: ensino especializado: educação. 
MAGALHÃES, Maria Helena de Andrade. Leitura recreativa na escola de $1^{\circ} \mathrm{grau}$ da rede oficial municipal de ensino de Belo Horizonte. Belo Horizonte: Escola de Biblioteconomia, Universidade Federal de Minas Gerais, 1980. 117 f. (dissertação)

Resumo: Estudo sobre leitura recreativa em escolas municipais de $1^{\circ} \mathrm{grau}$, da rede oficial de ensino de Belo Horizonte, visando à obtenção de informações sobre as preferências de lazer e leitura dos alunos de $5^{\mathrm{a}}$ a $8^{\mathrm{a}}$ séries; facilidades de acesso ao livro proporcionadas pela escola; atividades desenvolvidas por professores e bibliotecários para incentivar a leitura recreativa. Foram aplicados questionários a 660 alunos e 45 professores de Português e entrevistados 8 bibliotecários. Os dados obtidos forneceram, entre outras, as seguintes informações: a) A leitura ocupa posição secundária entre as atividades recreativas, não sendo considerada lazer principal pelos alunos; b) Os livros de literatura contendo aventuras e histórias de amor foram os preferidos dos alunos. c) O professor de Português faz indicações de livros para leitura obrigatória e desenvolve atividades de incentivo e verificação de leitura; d) O desempenho da biblioteca escolar foi considerado pouco significativo em relação à leitura recreativa. São sugeridas outras pesquisas abordando diferentes aspectos do assunto.

MAGALHÃES, Maria Helena de Andrade. Uma leitura... da leitura na escola de primeiro grau. São Paulo: Faculdade de Educação, Universidade de São Paulo, 1992. 196 f. (tese)

Resumo: Pesquisa realizada em escola de primeiro grau (Centro Pedagógico UFMG), com o objetivo de investigar a utilização do texto escrito no ensino de três disciplinas de conteúdo específico (História, Geografia e Ciências). O procedimento metodológico incluiu: a observação das aulas dessas disciplinas em uma classe de quinta série e outra de oitava, durante o primeiro semestre letivo de 1991; entrevista com cinco professores, vinte e quatro alunos e duas profissionais da biblioteca escolar local; análise de textos produzidos pelos alunos, a partir de atividades de pesquisa escolar. Foram feitas, dentre outras, as seguintes constatações: a) o aluno, em geral, é pouco preparado para a leitura de textos escritos - raramente se verificou o levantamento de seu conhecimento prévio sobre o assunto, condição fundamental para a compreensão de um texto. A leitura tinha por objetivo, quase sempre, a avaliação do aluno. b) a leitura oral alternada entre os alunos, com participação eventual do professor, foi a forma mais utilizada para leitura de textos informativos, durante as aulas observadas. c) a utilização de estratégias de leitura - tanto as de ensino como as de aprendizagem - praticamente não foi percebida durante a observação em classe; d) os trabalhos escritos pelos alunos, resultantes da atividade de pesquisa escolar, não conseguiram ultrapassar a cópia de trechos de enciclopédias e de outras fontes de informação; e) a biblioteca da escola investigada participa timidamente do processo de ensino, atuando de forma isolada e limitando-se, muitas vezes, ao fornecimento de materiais bibliográficos; f) existe um distanciamento entre o discurso do professor e sua prática pedagógica. Embora reconheça as falhas e dificuldades relacionadas à leitura de textos e à pesquisa escolar, o professor raramente consegue superar essas dificuldades. 
OLIVEIRA, Hamilton Vieira de. Bibliotecas escolares e o planejamento do processo educativo em escolas publicas de Brasília, DF. Brasília: Universidade de Brasília, Departamento de Ciência da Informação e Documentação, 1999. 132 f (tese)

Resumo: Estudo descritivo sobre a participação dos responsáveis por bibliotecas escolares no planejamento do processo educativo em escolas públicas de quinta a oitava séries em Brasília - DF. Utiliza a metodologia de estudo de caso e através de observação simples e aplicação de entrevistas levanta as opiniões dos segmentos profissionais que atuam na escola para identificar os fatores que impedem ou dificultam tal participação. Confirma o pressuposto da não participação e conclui que a falta de uma prática consolidada de planejamento pedagógico participativo nas escolas decorre de fatores de ordem administrativa, política e de cultura institucional, não cabendo atribui-la a fatores isolados.

SANTOS, Gildenir Carolino. Estudo da interlocução entre biblioteca-escolatecnologia, baseada na Internet: um estudo de caso na Escola Estadual Sérgio Perreira Porto. Campinas: Pontifícia Universidade Católica de Campinas, 2002. 181 f. (dissertação)

Resumo: Através de um estudo de caso, são analisadas as concepções pedagógicas que embasam a construção da prática de uma metodologia técnicobiblioteconômica em uma escola pública de ensino fundamental. Sob a interlocução biblioteca-escola-tecnologia, a pesquisa de campo foi realizada numa das 4as séries do Ensino Fundamental, da Escola Pública Sérgio Pereira Porto, localizada no interior do campus da UNICAMP, enfocando a atuação de um bibliotecáriopesquisador, dos alunos da 4a série do Ensino Fundamental e de uma professora desta série. Serão levantadas características do trabalho bibliotecário na escola ao identificar os referenciais teóricos-metodológicos que orientam a ação dos sujeitos, nas suas tentativas de superarem uma visão reprodutora do ensino, firmadas no compromisso da construção de uma biblioteca digital escolar com o uso das Tecnologias de Informação e Comunicação (TIC), e ao mesmo tempo usando-a como instrumento construtivista em sala de aula. A análise das concepções pedagógicas sobre 0 trabalho biblioteconômico com interface de auxiliar 0 professor e tornar o aluno capaz e livre para interferir no processo de sua aprendizagem, proporcionando ao aluno, um melhor rendimento em sala de aula, estimulada pela metodologia aplicada para o desenvolvimento e a construção da biblioteca digital escolar como modelo padrão para outras escolas.

TARGINO, Maria das Graças. A biblioteca na concepção de escolares: influencia de variáveis do ambiente escolar. João Pessoa: Centro de Ciências Sociais Aplicadas, Universidade Federal da Paraíba, 1983. 187 f. (dissertação)

Resumo: O objetivo deste estudo foi verificar o conceito de biblioteca entre escolares, no sentido de avaliar a influência de variáveis do ambiente escolar, quanto ao tipo de escola freqüentada (pública ou privada) e à existência ou não de biblioteca no educandário. Para este fim, após a introdução de noções sobre as interpretações teóricas concernentes ao conceito do conceito e sua aprendizagem, estabeleceu-se um paradigma para avaliar o grau de proximidade ou de 
afastamento dos conceitos expressos pelos alunos quanto à instituição biblioteca. Esta avaliação também permitiu estabelecer comparação entre as concepções emitidas pelos usuários e aquelas apresentadas na literatura biblioteconômica. Serviram como informantes 200 crianças de ambos os sexos, com idade variante entre dez a treze anos, matriculados na quinta série do ensino público e privado, na cidade de João Pessoa (PB). Os sujeitos foram selecionados de modo a constituírem quatro grupos de 50 elementos cada um: sujeitos de escolas públicas com biblioteca, sujeitos de escolas particulares com biblioteca, sujeitos de escolas públicas sem biblioteca, sujeitos de escolas particulares sem biblioteca. Aos escolares selecionados foi aplicado, em suas próprias salas de aula, pela pesquisadora, um questionário sucinto que além de questões de identificação, pedia que escrevessem o que era a biblioteca e para que servia. Os resultados mostraram que as diferenças entre os grupos foram estatisticamente insignificantes e que, de modo geral, os conceitos foram elementares, muito aquém dos propostos pelo referencial teórico. Isto pode significar que, tanto nas escolas públicas como particulares, independente destas possuírem ou não biblioteca, a criança pode não estar tendo ambiente propício à formação e/ou aprimoramento do conceito da mencionada instituição. Foram apresentadas sugestões visando ao desenvolvimento da biblioteca como instituição social. 


\section{Referências bibliográficas}

ABREU, Vera Lúcia Furst Gonçalves. A coleção da biblioteca escolar. In: CAMPELLO, Bernadete et al. A biblioteca escolar: temas para uma prática pedagógica. 2. ed. Belo Horizonte: Autêntica, 2005.p. 29-32.

. Pesquisa escolar. In: CAMPELLO, Bernadete et al. A biblioteca escolar: temas para uma prática pedagógica. 2. ed. Belo Horizonte: Autêntica, 2005.p. 2528.

AMORIM, Galeno (Org.); ALENCAR, Chico et. al. Políticas públicas do livro e da leitura. Brasília: Cultura Acadêmica; Organização dos Estados Americanos, 2006, $61 \mathrm{p}$.

ANDRADE, Maria Eugênia Albino. Biblioteca e educação infantil. In: CAMPELLO, Bernadete. A biblioteca escolar: temas para uma prática pedagógica. 2. ed. Belo Horizonte: Autêntica, 2005.p. 55-60.

ARAÚJO, Elliany Alvarenga; DIAS, Guilherme Atayde. A atuação profissional do bibliotecário no contexto da sociedade da informação. In: OLIVEIRA, Marlene de. (coord.); CENDÓN, Beatriz Valadares et. al. Ciência da Informação e Biblioteconomia: novos conteúdos e espaços de atuação. Belo Horizonte: Editora UFMG, 2005. p. 111-122.

ARRUDA, Susana Margaret; CHAGAS, Joseane. Glossário de Biblioteconomia e Ciências afins: português-inglês. Florianópolis: Cidade Futura, 2002. 232 p.

BAHIA (Estado). Secretaria Municipal de Educação Cultura - SMEC.

Coordenadoria de Ações Socioeducativas/Subcoordenadoria de Assistência ao Educando - CASISUAE. Sistema Informatizado de Bibliotecas Escolares.

Disponível em: <http://www.vivaleitura.com.br/pnll2/mapa show.asp?proj=211>. Acesso em: 20 maio 2009.

BELLUZZO, Regina Célia Baptista. Como desenvolver a Competência em Informação $(\mathrm{Cl})$ : uma mediação integrada entre a biblioteca e a escola. CRB-8 Digital, São Paulo, v. 1, n. 2, p. 11-14, out. 2008. Disponível em: <http://www.crb8.org.br/ojs/index.php/crb8digital/article/viewFile/13/17>. Acesso em: 06 maio 2009. 
BICHERI, Ana Lúcia Antunes de Oliveira. A mediação do bibliotecário na pesquisa escolar face a crescente virtualização da informação. Marília: UNESP Universidade Estadual Paulista, 2008. 197 f. Disponível em:

$<$ http://www.marilia.unesp.br/Home/Pos-

Graduacao/Cienciadalnformacao/Dissertacoes/bicheri alao me mar.pdf >. Acesso em: 04 maio 2009.

BORGES, Maria Alice Guimarães. A compreensão da sociedade da informação. Ci. Inf., Brasília, v. 29, n. 3, p. 25-32, dez. 2000.

BRASIL. Ministério de Educação. O livro didático e sua utilização. In: TAVARES, Denise Fernandes. A biblioteca escolar: conceituação, organização e funcionamento. Orientação do leitor e do professor. São Paulo: Livros Irradiantes S. A.; Instituto Nacional do Livro - MEC, 1973. p. 39-43.

BRASIL. Plano Nacional do Livro e da Leitura. Disponível em: <http://www.pnll.gov.br/>. Acesso em: 16 jun. 2009.

BRASIL. Prêmio Vivaleitura. Disponível em: < http://www.premiovivaleitura.org.br/default1.asp>. Acesso em: 10/06/2009.

BRASIL. Prêmio Vivaleitura. Projeto de Leitura Bibliotecas Escolares: Palavras Andantes (Londrina-PR). Disponível em:

http://www.premiovivaleitura.org.br/default1.asp?page=2009 venc2.asp. Acesso em: 15 jun. 2009.

CALDEIRA, Paulo da Terra. O espaço físico da biblioteca. In: CAMPELLO, Bernadete et al. A biblioteca escolar: temas para uma prática pedagógica. 2. ed. Belo Horizonte: Autêntica, 2005. p. 47-49.

CALDIN, Clarice Fortkamp. Reflexões acerca do papel do bibliotecário de biblioteca escolar. Revista ACB: Biblioteconomia em Santa Catarina, Florianópolis, v.10, n. 2, p. 163-168, 2005.

CAMPELLO, Bernadete. A competência informacional na educação para o século XXI. In: CAMPELLO, Bernadete et. al. A biblioteca escolar: temas para uma prática pedagógica. 2. ed. Belo Horizonte: Autêntica, 2005. p. 9-11.

Biblioteca e Parâmetros Curriculares Nacionais. In: CAMPELLO,

Bernadete et. al. A biblioteca escolar: temas para uma prática pedagógica. 2. ed. Belo Horizonte: Autêntica, 2005. p. 17-19. 
A Internet e a pesquisa escolar: um panorama do uso da Web por alunos do ensino fundamental. In: CONGRESSO BRASILEIRO DE BIBLIOTECONOMIA E DOCUMENTAÇÃO, 19., 2000, Porto Alegre, Proceedings..., Porto Alegre: CEPUC RS, 2000, 27 p. Disponível em: <http://dici.ibict.br/archive/00000832/01/T029.pdf>. Acesso em: 25. abr. 2009.

. O movimento da competência informacional: uma perspectiva para o letramento informacional. Ci. Inf., Brasília, v. 32, n. 3, p. 28-37, set./dez. 2003. Disponível em: < http://revista.ibict.br/index.php/ciinf/article/view/26/22>. Acesso em: 10 jan. 2009.

CARVALHO, Maria da Conceição. Escola, biblioteca e leitura. In: CAMPELLO, Bernadete et. al. A biblioteca escolar: temas para uma prática pedagógica. 2. ed. Belo Horizonte: Autêntica, 2005. p. 21-23.

. Internet e pesquisa escolar. In: CAMPELLO, Bernadete et. al. A biblioteca escolar: temas para uma prática pedagógica. 2. ed. Belo Horizonte: Autêntica, 2005. p. 33-36.

. Uma política de desenvolvimento de coleção para a biblioteca do Instituto de Educação de Minas Gerais. Revista da Escola de Biblioteconomia da UFMG, Belo Horizonte, v. 9, n. 2, p. 195-216, set. 1980.

CONSELHO FEDERAL DE BIBLIOTECONOMIA. Projeto Mobilizador Biblioteca Escolar: construção de uma Rede de Informações para o Ensino Público.

Disponível em: <http://www.cfb.org.br/UserFiles/File/PROMOBILFINAL.pdf>. Acesso em: 31 maio 2009.

CUNHA, Murilo Bastos da; CAVALCANTI, Cordélia Robalinho de Oliveira. Dicionário de Biblioteconomia e Arquivologia. Brasília: Briquet de Lemos / Livros, 2008. p. 2.

FERREIRA, Carminda Nogueira de Castro. Reforma de ensino e biblioteca. Revista de Biblioteconomia de Brasília, v. 5, n. 2, p. 707-712, jul./dez. 1977.

FRAGOSO, Graça Maria. Biblioteca na escola. Revista ACB: Biblioteconomia em Santa Catarina, Florianópolis, v. 7, n. 1, p. 124-131, 2002. Disponível em: < http://dici.ibict.br/archive/00000883/01/Rev\%5B1\%5D.AC-2005-78.pdf>. Acesso em: 25 nov. 2008. 
FURTADO, Cássia. A biblioteca escolar brasileira no sistema educacional da sociedade da informação. In: SEMINÁRIO BIBLIOTECA ESCOLAR ESPAÇO DE AÇÃO PEDAGÓGICA, 3., 2004, Belo Horizonte. Anais... Belo Horizonte: Grupo de Estudos em Biblioteca Escolar, UFMG, 2004, p. 250-263. Disponível em: $<$ http://www.eci.ufmg.br/gebe/downloads/317.pdf>. Acesso em: 14 mar. 2009.

GARCEZ, Elaine F.; BLATTMANN, Ursula. Recursos informativos - acervo: debatedores. In: MACEDO, Neusa Dias de (Org.). Biblioteca escolar brasileira em debate: da memória virtual a um fórum virtual. São Paulo: SENAC; CRB $8^{a}$ região, 2005. p. 326-328.

GONZÁLES, Daniel. Prefácio. In: In: AMORIM, Galeno (Org.); ALENCAR, Chico et al. Políticas públicas do livro e leitura. Brasília: Organização dos Estados Iberoamericanos; São Paulo: Cultura Acadêmica, 2006. p. 7-9.

GOVERNO DO ESTADO DO PARÁ. Secretaria de Estado de Educação (SEDUC). Secretaria Adjunta de Ensino (SAEN). Sistema Estadual de Bibliotecas Escolares. Disponível em: <http://www.vivaleitura.com.br/pnll2/mapa show.asp?proj=972>. Acesso em: 15 jun. 2009.

GRUPO DE ESTUDOS SOBRE BIBLIOTECA ESCOLAR. Disponível em: http://www.eci.ufmg.br/gebel. Acesso em: maio de 2009.

MACEDO, Neusa Dias de (Org.). Biblioteca escolar brasileira em debate: da memória profissional a um fórum virtual. São Paulo: SENAC; Conselho Regional de Biblioteconomia $8^{a}$ região, 2005. 446 p.

MACEDO, Neusa Dias de (Org.). Orientação bibliográfica ao leitor: mensagem ao professor secundário, por um bibliotecário. In: Biblioteca escolar brasileira em debate: da memória profissional a um fórum virtual. São Paulo: SENAC; Conselho Regional de Biblioteconomia $8^{\mathrm{a}}$ região, 2005. p. 80-84.

MARQUES NETO, José Castilho. Ano ibero-americano da leitura, o ano que não deve acabar. In: AMORIM, Galeno (Org.); ALENCAR, Chico et al. Políticas públicas do livro e leitura. Brasília: Organização dos Estados Ibero-americanos; São Paulo: Cultura Acadêmica, 2006. p. 19-29.

MARTUCCI, Elizabeth M. Financiamento, legislação e redes: debatedores. In: MACEDO, Neusa Dias de (Org.). Biblioteca escolar brasileira em debate: da memória profissional a um fórum virtual. São Paulo: SENAC; Conselho Regional de Biblioteconomia 8 ${ }^{\mathrm{a}}$ região, 2005. p. 218-225. 
MILANESI, Luís. Biblioteca. São Paulo: Ateliê Editorial, 2005. 116 p.

MODESTO, Fernando. Financiamento, legislação e redes: debatedores. In: MACEDO, Neusa Dias de (Org.). Biblioteca escolar brasileira em debate: da memória profissional a um fórum virtual. São Paulo: SENAC; Conselho Regional de Biblioteconomia 8a região, 2005. p. 225-229.

MORO, Eliane Lourdes da Silva; SABADINI, Fabiane; ESTABEL, Lizandra Brazil. A integração dos atores - alunos, educadores e bibliotecários - na realização da pesquisa escolar através da utilização das tecnologias de informação e comunicação. In: SEMINÁRIO BIBLIOTECA ESCOLAR, 3., 2004, Belo Horizonte, Anais... , Belo Horizonte: Grupo de Estudos em Biblioteca Escolar da Escola de Ciência da Informação da UFMG, 2004. 12 p.

ORGANIZAÇÃO DOS ESTADOS AMERICANOS. CASTRILLON, Silvia (org.); PATTEN DE OCAMPO, Elia Maria Van. Modelo flexível para um sistema nacional de bibliotecas escolares: Colômbia, Costa Rica, Peru, Venezuela. Brasília: Febab, 1985. $283 \mathrm{p}$.

OBSERVATÓRIO DO LIVRO E DA LEITURA. Retratos da leitura no Brasil. 2. ed. São Paulo: Imprensa Oficial do Estado; Instituto Pró-livro, 2007. 121 p. Disponível em: < http://www.prolivro.org.br/ipl/publier4.0/dados/anexos/48.pdf>. Acesso em: 13 abr. 2009.

PERUCCHI, Valmira. A importância da biblioteca nas escolas públicas de Criciúma - Santa Catarina. Revista ACB: Biblioteconomia em Santa Catarina, Florianópolis, v. 4, n. 4, p. 80-97, 1999. Disponível em: <

http://revista.acbsc.org.br/index.php/racb/article/view/341/404>. Acesso em: 12 jan. 2009.

PIMENTEL, Maria das Graças. A biblioteca pública e a inclusão digital: desafios e perspectivas na era da informação. Brasília: Universidade de Brasília, 2006. 242 f. Disponível em: < http://bdtd.bce.unb.br/tedesimplificado/tde busca/arquivo.php?codArquivo=1025>. Acesso em: 30 nov. 2008.

POLKE, Ana Maria Athayde. A biblioteca escolar e o seu papel na formação de hábitos de leitura. R. Esc. Bibliotecon. UFMG, Belo Horizonte, v. 2, n. 1, p. 60-72, mar. 1973. Disponível em: < http://www.eci.ufmg.br/rebonline/>. Acesso em: 12 abr. 2009. 
SANTOS, Inácia Rodrigues dos. A biblioteca escolar e atual pedagogia brasileira. Revista de Biblioteconomia de Brasília, Brasília, v. 1, n. 2, p. 145-149, jul./dez. 1973.

SENADO FEDERAL. Agência Senado. CE recebe sugestões para aperfeiçoamento de bibliotecas. Disponível em:

$<$ http://www.senado.gov.br/Agencia/verNoticia.aspx?codNoticia=88922\&codAplicati vo=2>. Acesso em: 31 maio 2009.

SILVA, Ellen Crista da. Revisão de literatura [mensagem pessoal]. Mensagem recebida por<pollyanabatista@gmail.com> em 24 maio 2009.

SILVA, Waldeck Carneiro da. Miséria da biblioteca escolar. São Paulo: Cortez, 1995. 118p. (Coleção Questões da Nossa Época, 45)

TAVARES, Denise Fernandes. Biblioteca escolar: conceituação, organização e funcionamento. Orientação do leitor e do professor. São Paulo: LISA Livros Irradiantes S. A.; Instituto Nacional do Livro, 1973. 161 p.

VÁLIO, Else Benetti Marques. Biblioteca escolar: uma visão histórica.

Transinformação, v. 2, n. 1, p. 15-24, jan./abr. 1990.

VIANNA, Márcia Milton. A Internet na biblioteca escolar. In: CAMPELLO, Bernadete et al. A biblioteca escolar: temas para uma prática pedagógica. 2. ed. Belo Horizonte: Autêntica, 2005. p. 37-41.

. A organização da coleção. In: CAMPELLO, Bernadete et al. A biblioteca escolar: temas para uma prática pedagógica. 2. ed. Belo Horizonte: Autêntica, 2005. p. 43-46. 